Romulo Loss Mattedi

\title{
Carcinomas uroteliais de bexiga : aspectos anatomopatológicos e imuno-histoquímicos. Pesquisa de metaloproteinases de matriz utilizando a técnica de tissue microarray (TMA)
}

Tese apresentada à Faculdade de Medicina da Universidade de São Paulo para obtenção do título de Doutor em Ciências

Programa de: Patologia

Orientador: Prof. Dr. Venâncio Avancini Ferreira Alves

São Paulo 
Dados Internacionais de Catalogação na Publicação (CIP)

Preparada pela Biblioteca da

Faculdade de Medicina da Universidade de São Paulo

\section{Creprodução autorizada pelo autor}

Mattedi, Romulo Loss

Carcinomas uroteliais de bexiga : aspectos anatomopatológicos e imunohistoquímicos. Pesquisa de metaloproteinases de matriz utilizando a técnica de tissue microarray (TMA) / Romulo Loss Mattedi.-- São Paulo, 2011.

Tese(doutorado)--Faculdade de Medicina da Universidade de São Paulo.

Programa de Patologia.

Orientador: Venâncio Avancini Ferreira Alves.

Descritores: 1.Carcinoma urotelial de bexiga 2.Metaloproteinase da matriz 3.Imunoistoquímica 4.Carcinoma sarcomatoide 5.Transição epitelial-mesenquimal 6.Padrão de invasão tumoral

USP/FM/DBD-182/11 


\section{Agradecimentos}

Agradeço especialmente ao Prof. Dr. Venâncio Avancini Ferreira Alves pela orientação e apoio durante os períodos de residência médica e pósgraduação, sempre com incomparável entusiasmo e a valorização da Patologia como especialidade e ferramenta de integração médica.

Ao Prof. Dr. Paulo Roberto Merçon de Vargas do Departamento de Patologia da Universidade Federal do Espírito Santo pelo aprendizado e apoio durante a graduação, os ensinamentos sobre a importância da Patologia e pela contribuição na formação do meu conhecimento médico.

Ao Dr. Kleber Simões do Espírito Santo pela incansável ajuda no desenvolvimento deste trabalho e inestimável amizade.

Aos amigos da Divisão de Anatomia Patológica do Hospital das Clínicas da FMUSP e do Setor de Anatomia Patológica do Salomão \& Zoppi Medicina Diagnóstica, pelas trocas de experiências profissionais e ensinamentos constantes em patologia cirúrgica.

Aos pesquisadores do Laboratório de Investigação Médica 14 (LIM-14) da Faculdade de Medicina da USP, em especial Alda Wakamatsu e Cinthya Cirqueira, pelo apoio técnico na confecção dos TMAs e nos estudos imunohistoquímicos.

Aos amigos da Divisão de Clínica Urológica do HCFMUSP, em especial ao Prof. Dr. Marcos Francisco Dall'Oglio, pela colaboração nas informações clínicas dos pacientes, pelo convívio e pela oportunidade de aprendizado em uropatologia. 
Aos técnicos e funcionários da Divisão de Anatomia Patológica do HCFMUSP pela colaboração neste trabalho e amizade desde a época de residência médica.

Aos meus parentes e amigos pela compreensão, paciência e estímulo constantes.

Por fim agradeço à minha querida família: meu pai Hermenegildo, minha mãe Ana Luiza e minhas irmãs Domenica e Daniela. Pela vida em família, compreensão, incansável força e oração constantes. Com todo meu carinho e admiração. 


\section{Normalização Adotada}

Esta tese está de acordo com as seguintes normas, em vigor no momento desta publicação:

Referências: adaptado de International Committee of Medical Journals Editors (Vancouver).

Universidade de São Paulo. Faculdade de Medicina. Divisão de Biblioteca e Documentação. Guia de apresentação de dissertações, teses e monografias. Elaborado por Anneliese Carneiro da Cunha, Maria Julia de A. L. Freddi, Maria F. Crestana, Marinalva de Souza Aragão, Suely Campos Cardoso, Valéria Vilhena. 3a ed. São Paulo: Divisão de Biblioteca e Documentação; 2011.

Abreviaturas dos títulos dos periódicos de acordo com List of Journals Indexed in Índex Medicus. 


\section{Sumário}

Lista de abreviaturas

Lista de símbolos

Lista de siglas

Lista de tabelas

Lista de figuras

Resumo

Summary

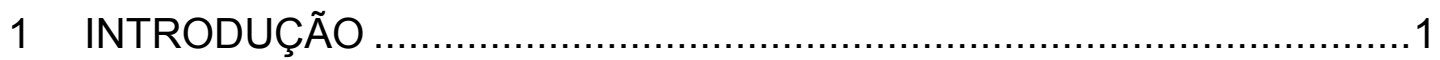

1.1 Câncer de bexiga - aspectos epidemiológicos ...........................2

1.2 Fatores ambientais associados ao carcinoma de bexiga ................. 3

1.3 Fatores genéticos associados ao carcinoma de bexiga .................5

1.4 Aspectos anatomopatológicos de importância prognóstica no

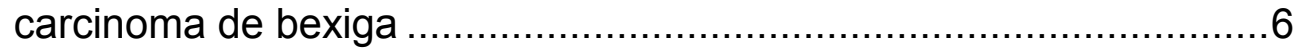

1.5 Principais vias moleculares relacionadas à carcinogênese urotelial ...12

1.6 Microambiente tumoral e progressão do câncer ........................... 14

1.6.1 Metaloproteinases de matriz extracelular - aspectos gerais ...16

1.6.2 Transição epitélio-mesênquima ...................................... 19

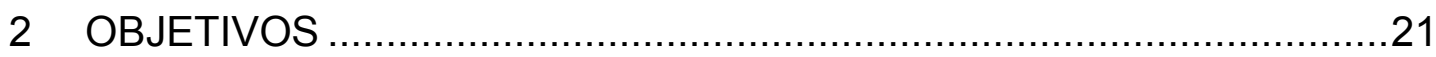

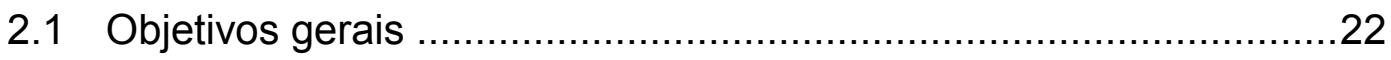

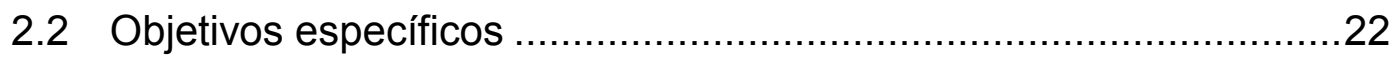

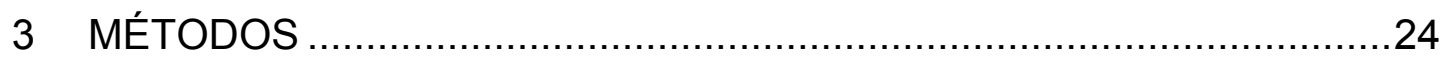

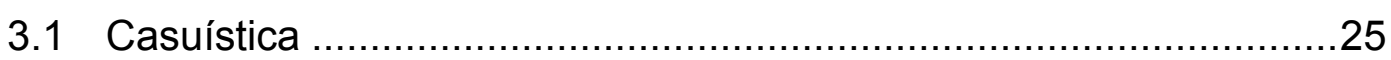

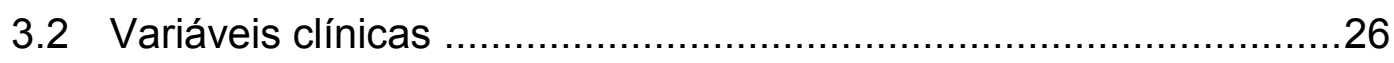

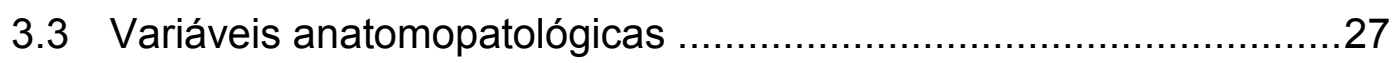

3.4 Construções das micromatrizes teciduais (TMA) ......................... 34

3.5 Estudos imuno-histoquímicos ............................................. 35

3.5.1 Anticorpos primários utilizados e padronização dos ensaios...35

3.5.2 Interpretação dos resultados das reações imunohistoquímicas - análise da reatividade .................................37

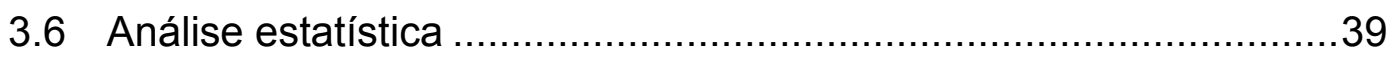


4.1 Características clínico-patológicas

4.2 Avaliação imuno-histoquímica da expressão das metaloproteinases de matriz extracelular no tumor primário e na metástase linfonodal

4.2.1 Expressão imuno-histoquímica de MMP-2 no tumor primário

4.2.2 Expressão imuno-histoquímica de MMP-2 na metástase linfonodal.

4.2.3 Expressão imuno-histoquímica de MMP-9 no tumor primário

4.2.4 Expressão imuno-histoquímica de MMP-9 na metástase linfonodal.

4.2.5 Expressão imuno-histoquímica de MMP-14 no tumor primário

4.2.6 Expressão imuno-histoquímica de MMP-14 na metástase linfonodal

4.3 Análise das associações entre as variáveis anatomopatológicas e os perfis de reatividade das metaloproteinases de matriz MMP2, MMP-9 e MMP-14

4.3.1 Súmula das associações entre as características anatomopatológicas e o escore para a imunoexpressão de MMP-2

4.3.2 Súmula das associações entre as características anatomopatológicas e o escore para a imunoexpressão de MMP-9

4.3.3 Súmula das associações entre as características anatomopatológicas e o escore para a imunoexpressão de MMP-14

4.3.4 Avaliação detalhada da expressão de MMP-2 no tumor primário e na metástase linfonodal

4.3.4.1 Expressão global de MMP-2 no tumor primário

4.3.4.2 Expressão de MMP-2 no epitélio neoplásico do tumor primário.

4.3.4.3 Expressão de MMP-2 no estroma do tumor primário ..69

4.3.4.4 Expressão de MMP-2 na metástase linfonodal

4.3.5 Avaliação detalhada da expressão de MMP-9 no tumor primário e na metástase linfonodal

4.3.5.1 Expressão global de MMP-9 no tumor primário 
4.3.5.2 Expressão de MMP-9 no epitélio neoplásico do tumor primário

4.3.5.3 Expressão de MMP-9 no estroma do tumor primário ..75

4.3.5.4 Expressão de MMP-9 na metástase linfonodal ...........78

4.3.6 Avaliação detalhada da expressão de MMP-14 no tumor

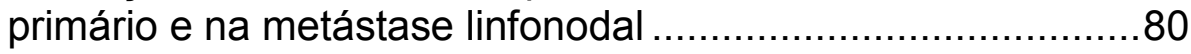

4.3.6.1 Expressão global de MMP-14 no tumor primário .........80

4.3.6.2 Expressão de MMP-14 no epitélio neoplásico do tumor primário

4.3.6.3 Expressão de MMP-14 no estroma neoplásico do tumor primário

4.3.6.4 Expressão de MMP-14 na metástase linfonodal

5 DISCUSSÃO

5.1 Aspectos epidemiológicos da casuística

5.2 Associação das variáveis anatomopatológicas com a imunoexpressão das MMPs no tumor primário

5.3 Associação das variáveis anatomopatológicas com a imunoexpressão das MMPs na metástase linfonodal ...................106

6 CONCLUSÕES

7 ANEXOS

Anexo A: Protocolo de estudo anatomopatológico

Anexo B: Protocolo de estudo imuno-histoquímico

Anexo C: Parte 1. Banco de dados - Variáveis clínico-patológicas da casuística (61 casos)

Anexo D: Estudo imuno-histoquímico de MMP-2 - distribuição da positividade, intensidade e escore no tumor primário e na metástase linfonodal

Anexo E: Estudo imuno-histoquímico de MMP-9 - distribuição da positividade, intensidade e escore no tumor primário e na metástase linfonodal

Anexo F: Estudo imuno-histoquímico de MMP-14 - distribuição da positividade, intensidade e escore no tumor primário e na metástase linfonodal.

APÊNDICE 


\section{Lista de Abreviaturas}

\begin{tabular}{|c|c|}
\hline CaUPAG & carcinoma urotelial papilífero de alto grau \\
\hline CaUPBxG & carcinoma urotelial papilífero de baixo grau \\
\hline CIS & carcinoma urotelial in situ \\
\hline D.P. & desvio padrão da média \\
\hline et al. & e outros \\
\hline $\mathrm{H}_{2} \mathrm{O}_{2}$ & peróxido de hidrogênio \\
\hline IC & intervalo de confiança \\
\hline $\mathrm{IH}$ & imuno-histoquímica \\
\hline ILV & invasão linfovascular \\
\hline LIM-14 & Laboratório de Investigação Médica 14 \\
\hline MEC & matriz extracelular \\
\hline MMP & metaloproteinases de matriz \\
\hline mRNA & ácido ribonucleico mensageiro \\
\hline MT-MMP & metaloproteinases de matriz tipo-membrana \\
\hline$M: F$ & proporção masculino/feminino \\
\hline NUPBxPM & neoplasia urotelial papilífera de baixo potencial de malignidade \\
\hline PCR & reação em cadeia da polimerase (polymerase chain reaction) \\
\hline RTUTB & ressecção transuretral de tumor de bexiga \\
\hline TE-M & transição epitélio-mesênquima \\
\hline TIMP & inibidores teciduais de metaloproteinases de matriz \\
\hline TMA & micromatriz tecidual (tissue microarray) \\
\hline$V S$ & versus \\
\hline
\end{tabular}




\section{Lista de Símbolos}

$\begin{array}{ll}\% & \text { por cento } \\ > & \text { maior ou igual } \\ < & \text { maior que } \\ = & \text { menor que } \\ { }^{\circ} \mathrm{C} & \text { igual a } \\ \mathrm{p} & \text { Grau Celsius } \\ \mathrm{pH} & \text { nível de significância estatística } \\ \mathrm{x}^{2} & \text { potencial hidrogeniônico } \\ \alpha & \text { qui-quadrado } \\ \mathrm{cm} & \text { alfa } \\ \mathrm{mm} & \text { centímetro } \\ \mu \mathrm{mM} & \text { milímetro } \\ \mathrm{dKa} & \text { micrômetro } \\ & \text { kilodalton } \\ & \text { miliMol }\end{array}$




\section{Lista de Siglas}

$\begin{array}{ll}\text { AJCC } & \text { American Joint Comittee on Cancer } \\ \text { EUA } & \text { Estados Unidos da América } \\ \text { GLOBOCAN } & \text { Estatística Global de Câncer } \\ \text { HCFMUSP } & \begin{array}{l}\text { Hospital das Clínicas da Faculdade de Medicina da } \\ \text { Universidade de São Paulo }\end{array} \\ \text { IARC } & \text { International Agency for Research on Cancer } \\ \text { ISUP } & \text { International Society of Urological Pathology (ISUP) } \\ \text { ICESP } & \text { Instituto do Câncer do Estado de São Paulo } \\ \text { OMS } & \text { Organização Mundial da Saúde } \\ \text { PT } & \text { Estadiamento patológico do parâmetro "T" (tumor) } \\ \text { TNM } & \text { Estadiamento Tumor - LinfoNodo - Metástase }\end{array}$




\section{Lista de Tabelas}

Tabela 1 - Distribuição da frequência do escore global, no epitélio neoplásico e no estroma da imunoexpressão de MMP-2 no tumor primário.

Tabela 2 - Distribuição da frequência do escore da imunoexpressão de MMP-2 na metástase linfonodal

Tabela 3 - Distribuição da frequência do escore global, no epitélio neoplásico e no estroma da imunoexpressão de MMP-9 no tumor primário.

Tabela 4 - Distribuição da frequência do escore da imunoexpressão de MMP-9 na metástase linfonodal

Tabela 5 - Distribuição da frequência do escore global, no epitélio neoplásico e no estroma da imunoexpressão de MMP-14 no tumor primário

Tabela 6 - Distribuição da frequência do escore da imunoexpressão de MMP-14 na metástase linfonodal

Tabela 7 - Sumário das significâncias das associações entre as variáveis anatomopatológicas e o escore para MMP-2 $(p<0,05)$

Tabela 8 - Sumário das significâncias das associações entre as variáveis anatomopatológicas e o escore para MMP-9 $(p<0,05)$

Tabela 9 - Sumário das significâncias das associações entre as variáveis anatomopatológicas e o escore para MMP-14 $(p<0,05)$

Tabela 10 - Associação entre a imunoexpressão global de MMP-2 (escore) no tumor primário e o padrão arquitetural de invasão tumoral

Tabela 11 - Associação entre a imunoexpressão de MMP-2 no epitélio neoplásico do tumor primário (escore) e o padrão arquitetural de invasão tumoral 
Tabela 12 - Associação entre a imunoexpressão de MMP-2 no estroma do tumor primário (escore) e a atipia nuclear

Tabela 13 - Associação entre a imunoexpressão de MMP-2 no estroma do tumor primário (escore) e o componente sarcomatoide......69

Tabela 14 - Associação entre a imunoexpressão de MMP-2 no estroma do tumor primário (escore) e a porcentagem do componente sarcomatoide.

Tabela 15 - Associação entre a imunoexpressão de MMP-2 no estroma do tumor primário (escore) e a diferenciação escamosa

Tabela 16 - Associação entre a imunoexpressão de MMP-2 na metástase linfonodal (escore) e o tipo/configuração do tumor primário ....71

Tabela 17 - Associação entre a imunoexpressão global de MMP-9 no tumor primário (escore) e a diferenciação escamosa

Tabela 18 - Associação entre a imunoexpressão global de MMP-9 no tumor primário (escore) e o estádio tumoral agrupado pT2+pT3 versus $\mathrm{pT} 4$

Tabela 19 - Associação entre a imunoexpressão de MMP-9 no epitélio neoplásico do tumor primário (escore) e o estádio tumoral agrupado $\mathrm{pT} 2+\mathrm{pT} 3$ versus $\mathrm{pT} 4$

Tabela 20 - Associação entre a imunoexpressão de MMP-9 no epitélio neoplásico do tumor primário (escore) e 0 padrão arquitetural de invasão tumoral

Tabela 21 - Associação entre a imunoexpressão de MMP-9 no estroma do tumor primário (escore) e o padrão arquitetural de invasão tumoral

Tabela 22 - Associação entre a imunoexpressão de MMP-9 no estroma do tumor primário (escore) e a atipia nuclear

Tabela 23 - Associação entre a imunoexpressão de MMP-9 no estroma do tumor primário (escore) e o componente sarcomatoide......76

Tabela 24 - Associação entre a imunoexpressão de MMP-9 no estroma do tumor primário (escore) e a porcentagem do componente sarcomatoide. 
Tabela 25 - Associação entre a imunoexpressão de MMP-9 no estroma do tumor primário (escore) e o estádio tumoral (AJCC/TNM 2009).

Tabela 26 - Associação entre a imunoexpressão de MMP-9 na metástase linfonodal (escore) e o tipo/configuração do tumor primário ....78

Tabela 27 - Associação entre a imunoexpressão de MMP-9 na metástase linfonodal (escore) e atipia nuclear do tumor primário

Tabela 28 - Associação entre a imunoexpressão de MMP-9 na metástase linfonodal (escore) e o tipo da variante histológica do tumor primário

Tabela 29 - Associação entre a imunoexpressão global de MMP-14 no tumor primário (escore) e o padrão arquitetural de invasão tumoral

Tabela 30 - Associação entre a imunoexpressão de MMP-14 no epitélio neoplásico do tumor primário (escore) e o padrão arquitetural de invasão tumoral

Tabela 31 - Associação entre a imunoexpressão de MMP-14 no estroma do tumor primário (escore) e o componente sarcomatoide

Tabela 32 - Associação entre a imunoexpressão de MMP-14 no estroma do tumor primário (escore) e a porcentagem do componente sarcomatoide.

Tabela 33 - Associação entre a imunoexpressão de MMP-14 na metástase linfonodal (escore) e a porcentagem do componente sarcomatoide do tumor primário. 


\section{Lista de Figuras}

Figura 1. Aspectos morfológicos do carcinoma urotelial de bexiga. .45

Figura 2. Tipo/configuração da neoplasia e padrões arquiteturais de invasão tumoral.

Figura 3. Variantes histológicas e diferenciações divergentes do carcinoma urotelial de bexiga.

Figura 4. Componente sarcomatoide do carcinoma urotelial de bexiga......48

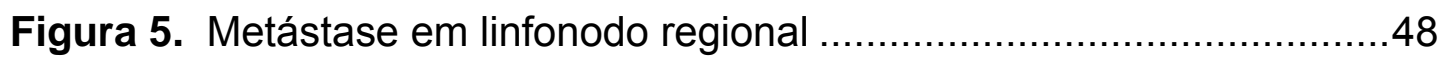

Figura 6. Expressão imuno-histoquímica de MMP-2 ..........................53

Figura 7. Expressão imuno-histoquímica de MMP-9 ..........................57

Figura 8. Expressão imuno-histoquímica de MMP-14 .........................62 


\section{Resumo}

Mattedi RL. Carcinomas uroteliais de bexiga : aspectos anatomopatológicos e imuno-histoquímicos. Pesquisa de metaloproteinases de matriz utilizando a técnica de tissue microarray (TMA) [Tese]. São Paulo: Faculdade de Medicina, Universidade de São Paulo; 2011. 141p.

OBJETIVOS: Estudar variáveis anatomopatológicas relacionadas à progressão tumoral em carcinomas uroteliais primários de bexiga e sua associação com a imunoexpressão de metaloproteinases de matriz (MMPs) 2, -9 e -14 no epitélio e no estroma dos tumores primários e nas metástases linfonodais. MÉTODOS: Sessenta e um casos de carcinomas uroteliais musculoinvasivos ou localmente avançados primários da bexiga operados no Hospital das Clínicas da Faculdade de Medicina da USP e no Instituto do Câncer do Estado de São Paulo, sendo 34 casos com metástase para linfonodo regional, foram caracterizados quanto ao gênero, idade, tamanho, focalidade, grau histológico, tipo/configuração neoplásica, tipo papilífero da neoplasia, padrão arquitetural de invasão tumoral, grau de atipia nuclear, componente sarcomatoide, diferenciações escamosa e glandular, variante histológica, invasões linfovascular e perineural, carcinoma in situ, estádio do tumor primário, metástase para linfonodo regional, tamanho da metástase e extensão extranodal. Amostras teciduais de 1,0 $\mathrm{mm}$ foram dispostas em micromatrizes teciduais (TMA) para pesquisa imuno-histoquímica $(\mathrm{IH})$ das enzimas MMP-2, MMP-9 e MMP-14. A expressão IH das MMPs foi graduada em uma escala semiquantitativa de 0 (ausência de expressão) até 20 (maior expressão). As associações entre a imunoexpressão das MMPs de forma global, no epitélio e estroma do tumor primário e na metástase linfonodal com as variáveis anatomopatológicas foram avaliadas através do teste do qui-quadrado de Pearson, sendo consideradas significativas ao nível de p<0,05. RESULTADOS: Trinta e seis, 57 e 60 casos do tumor primário foram positivos para MMP-2, MMP-9 e MMP-14, respectivamente. Nas metástases linfonodais, 20, 27 e 26 casos foram positivos para MMP-2, MMP-9 e MMP-14, respectivamente. A imunoexpressão global de MMP-2 no tumor primário mostrou-se associada com o padrão arquitetural de invasão $(p=0,022)$ e sua expressão no estroma com o grau de atipia nuclear $(p=0,032)$ e a porcentagem de componente sarcomatoide $(p=0,003)$. A imunoexpressão global de MMP-9 no tumor primário mostrou-se associada com diferenciação escamosa $(p=0,033)$. O padrão arquitetural de invasão relacionou-se com a expressão de MMP-9 no epitélio $(p=0,043)$ e no estroma $(p=0,044)$. A expressão de MMP-9 no estroma mostrou-se associada com o grau de atipia nuclear $(p=0,031)$, componente sarcomatoide $(p=0,036)$ e com a porcentagem desse componente no tumor 
primário $(\mathrm{p}=0,013)$. O estádio tumoral agrupado $\mathrm{pT2}+\mathrm{pT3}$ vs $\mathrm{pT} 4$ demonstrou associação com a MMP-9 expressa no epitélio $(p=0,049)$. Para a MMP-14, o padrão arquitetural de invasão demonstrou associação significativa com a imunoexpressão global $(p=0,022)$ e no epitélio tumoral $(p=0,045)$. A porcentagem de componente sarcomatoide relacionou-se ainda com a expressão estromal de MMP-14 $(p<0,001)$. Considerando a imunoexpressão de MMPs apenas na metástase linfonodal, houve associação significativa da MMP-9 com o tipo de variante histológica do tumor $(p=0,021)$ e da expressão de MMP-14 com a porcentagem de componente sarcomatoide no tumor primário $(p=0,017)$. CONCLUSÃO: $O$ estudo da imunoexpressão de MMP-2, MMP-9 e MMP-14 em amostras organizadas em TMA, tanto no epitélio como no estroma dos carcinomas uroteliais de bexiga e nas metástases de linfonodos regionais, demonstrou associações estatísticas com características anatomopatológicas reconhecidas como de prognóstico ruim para essas neoplasias, indicando a ação dessas enzimas na transição epitélio-mesênquima e nas etapas de progressão e metástase dos carcinomas uroteliais.

\section{Descritores:}

1.Carcinoma urotelial de bexiga 2.Metaloproteinase da matriz 3.Imunoistoquímica 4.Carcinoma sarcomatoide 5.Transição epitelialmesenquimal 6.Padrão de invasão tumoral 


\section{Summary}

Mattedi RL. Urothelial carcinomas of the urinary bladder : morphological and immunohistochemical aspects. Expression of the matrix metalloproteinases using the tissue microarray (TMA) technique [Thesis]. São Paulo: "Faculdade de Medicina, Universidade de São Paulo"; 2011. 141p.

OBJECTIVES: To study morphological features related to tumor progression in urothelial carcinoma of the urinary bladder and its association with immunohistochemical (IHC) expression of matrix metalloproteinases (MMPs) $-2,-9$ and -14 in epithelial and stromal cells of primary tumor and regional lymph node metastases. METHODS: Sixty-one cases of muscle-invasive or locally advanced urothelial carcinomas of the bladder operated on Clinic's Hospital of Faculty Medicine Sao Paulo University and the Cancer Institute of the State of Sao Paulo, with 34 cases showing regional lymph nodes metastases, were characterized regarding gender, age, tumor size, multifocality, histological grade, neoplastic type/configuration, papillary type, architectural pattern of invasive tumor, nuclear atypia, sarcomatoid component, squamous and glandular diffentiation, histological variants, lymphovascular and perineural invasion, carcinoma in situ, tumor stage, metastases to regional lymph nodes, metastases size and extranodal extension. Tissue samples of $1.0 \mathrm{~mm}$ were arranged in tissue microarrays blocks (TMA) for IHC detection of MMP-2, MMP-9 and MMP-14. The grading of expression of MMPs was determined to a semiquantitative scale from 0 (absence) to 20 (higher expression). The associations between the IHC global expression of MMPs, in epithelium and in stromal cells of the primary tumor and in the lymph node metastases with the morphological features were obtained through Pearson's chi-square (significant at $\mathrm{p}<0.05$ ). RESULTS: Thirty-six, 57 and 60 cases of primary tumor were positive for MMP-2, MMP-9 and MMP-14 respectively. In the lymph nodes metastases, 20, 27 and 26 cases were positive for MMP-2, MMP-9 and MMP-14 respectively. The global IHC expression of MMP-2 in primary tumor has been associated with the architectural pattern of invasion $(p=0.022)$. The expression in stromal cells were correlated with the degree of nuclear atypia $(p=0.032)$ and the percentage of sarcomatoid component $(p=0.003)$. The IHC expression of MMP-9 in primary tumor has been associated with squamous differentiation $(p=0.033)$. The architectural pattern of invasion was related to the expression of MMP-9 in epithelium $(p=0.043)$ and in the stroma $(p=0.044)$. Expression of MMP-9 in the stroma was associated with the degree of nuclear atypia $(p=0.031)$, sarcomatoid component $(p=0.036)$ and the percentage of this component in primary tumor $(p=0.013)$. The grouped 
tumoral stage pT2+pT3 vs pT4 showed association with MMP-9 expressed in epithelium $(p=0.049)$. For MMP-14, the architectural pattern of invasion showed significant association with global IHC expression $(p=0.022)$ and tumor epithelium $(p=0.045)$. The percentage of sarcomatoid component related to the estromal expression of MMP-14 $(p<0.001)$. Considering the IHC expression of MMPs in lymph nodes metastases, there was a significant association between MMP-9 with the type of histological variants $(p=0.021)$ and the expression of MMP-14 with the percentage of sarcomatoid component in primary tumor $(p=0.017)$. CONCLUSION: The study of IHC expression of MMP-2, MMP-9 and MMP-14 in bladder carcinoma samples arranged in TMA, both in epithelium and in stromal cells and regional lymph nodes metastases, demonstrated significant association with morphological features recognized as prognostically important for these tumors. These findings herald the importance of action of these enzymes in epithelialmesenchymal transition, providing basis for the understanding of tumoral progression and metastases in urothelial carcinoma.

\section{Descriptors:}

1.Urothelial carcinoma of the urinary bladder 2.Matrix metalloproteinases 3.Immunohistochemistry 4.Sarcomatoid carcinoma 5.Epithelialmesenchymal transition 6.Pattern of tumor invasion 
1 INTRODUÇÃO 


\subsection{Câncer de bexiga - aspectos epidemiológicos}

Segundo o último relatório da Agência Internacional para Pesquisa em Câncer (IARC) da Organização Mundial da Saúde (OMS), o impacto global do câncer mais que dobrou nos últimos 30 anos. Para o ano de 2008, excluídos os casos de tumores de pele não melanoma, o número estimado de casos novos de todos os tipos de câncer foi 12,7 milhões e, o número de mortes por câncer, 7,6 milhões (1).

As neoplasias da bexiga basicamente compreendem as derivadas do epitélio transicional ou urotelial, o mesmo que reveste as vias urinárias da pelve renal à uretra proximal. As estimativas do projeto GLOBOCAN 2008, que tem como objetivo a estimativa contemporânea da incidência e mortalidade da maioria dos cânceres em nível nacional para todos os países do mundo, revelam para o câncer de bexiga uma incidência mundial de 382660 casos novos para o ano de 2008 , o $9^{\circ}$ câncer mais incidente, com 294345 casos novos no gênero masculino e 88315 no feminino. Sua maior incidência é observada em países da Europa Ocidental e América do Norte. A prevalência de câncer de bexiga também é maior em países desenvolvidos, que supera aproximadamente em 6 vezes a de países em desenvolvimento. A mortalidade mundial estimada para o câncer de bexiga no ano de 2008 foi de 150282 óbitos (9ª maior), com 112308 óbitos entre os homens e 37974 óbitos entre as mulheres (2). 
De acordo com o banco de dados GLOBOCAN 2008, no Brasil o câncer de bexiga apresentou uma incidência de 6910 casos novos, sendo 5143 casos novos do gênero masculino e 1767 casos do feminino. A mortalidade na população brasileira foi estimada em 3201 óbitos, sendo 2223 entre os homens e 978 entre as mulheres (2).

\subsection{Fatores ambientais associados ao carcinoma de bexiga}

O uso do tabaco e a exposição ocupacional são os maiores fatores de risco nos países desenvolvidos, enquanto a infecção crônica pelo Schistosoma hematobium em países da África (particularmente o Egito) e do Oriente Médio são responsáveis por cerca de $50 \%$ dos casos (3). A maioria dos cânceres de bexiga associados ao $S$. hematobium são carcinomas epidermoides, enquanto que aqueles associados ao tabaco são carcinomas uroteliais.

A relação entre o câncer de bexiga e o uso do tabaco tem sido cogitada desde o final da década de 1950, e sua associação causal estabelecida na década de 1980, sendo hoje considerado o mais importante fator de risco para o desenvolvimento dessa neoplasia (4). Em meta-análise baseada em 21 trabalhos, Gandini et al. calcularam em 2,77 o risco relativo (IC 95\% = 2,17-3,54) de câncer no trato urinário inferior (especialmente na bexiga) na população de fumantes (5). Para ex-fumantes, o risco relativo calculado foi de 1,72 (IC $95 \%=1,46-2,04)$. Embora os efeitos do tabaco 
sobre o câncer de bexiga diminuam em ex-fumantes, o risco residual latente não desaparece por completo, mesmo após longos períodos de interrupção do seu uso (6). Em relação ao gênero e ao uso de tabaco, Castelao et al. demonstraram em um estudo realizado na Califórnia/EUA o maior risco de mulheres tabagistas desenvolverem câncer de bexiga em relação aos homens fumantes, comparando o número de cigarros consumidos $(p=0,016)(7)$.

Depois da pele e do trato respiratório, a bexiga é o principal órgão interno afetado por carcinógenos ocupacionais. A associação entre agentes carcinogênicos químicos encontrados em atividades ocupacionais e industriais e o câncer de bexiga é bem estabelecida, estimando-se que 20$27 \%$ dos casos desse câncer sejam relacionados com exposição ocupacional (8). O risco não depende somente do tipo de carcinógeno e sua intensidade de exposição, mas também da suscetibilidade individual ao câncer. Os agentes químicos mais importantes ligados ao câncer de bexiga são as aminas aromáticas, com destaque para a betanaftilamina, 4-aminobifenil e a benzidina. Essas substâncias são empregadas industrialmente como componente de tinta têxtil e agente antioxidante da borracha, além das indústrias de alumínio, mecânica e petroquímica. Em meta-análise publicada em 2008, Reulen et al. avaliaram 129 artigos publicados entre os anos de 1963 e 2008, com objetivo de demonstrar a associação entre atividades ocupacionais e os maiores índices de câncer de bexiga, destacando o risco associado a profissões ligadas à mineração, motorista de ônibus e trabalhadores da indústria de borracha (9). 


\subsection{Fatores genéticos associados ao carcinoma de bexiga}

O polimorfismo genético (diferentes formas alélicas em um mesmo locus) envolvendo genes de metabolização pode contribuir para o aumento da suscetibilidade individual ao câncer de bexiga, por alterar o metabolismo de carcinógenos como as aminas aromáticas e os hidrocarbonetos aromáticos policíclicos. Variabilidade no fenótipo e genótipo de enzimas metabolizadoras tem associação com aumento do risco de câncer de bexiga, principalmente quando detectadas em indivíduos com exposição ambiental e/ou ocupacional desfavorável (10).

O sistema enzimático $\mathrm{N}$-acetiltransferase (NAT) é responsável pela bioativação e detoxificação de aminas aromáticas. A perda de função dos dois alelos do gene NAT2 promove um genótipo de acetilação lenta, aumentando o risco de carcinoma de bexiga na presença da exposição a aminas aromáticas e ao tabaco, conforme demonstrado por García-Closas et al. (11). Outro grupo de enzimas responsáveis pela detoxificação por conjugação com o glutation é a família da glutation-S transferase (GST), que tem como substrato hidrocarbonetos aromáticos policíclicos e produtos do estresse oxidativo celular. A deleção do GSTM1, um polimorfismo comum em humanos, promove a perda da atividade enzimática e está associada ao câncer de bexiga. Em estudo caso-controle, García-Closas et al. também estimaram o odds ratio em 1,9 (IC 95\% = 1,4-2,7) para indivíduos com genótipo nulo de GSTM1 desenvolverem carcinoma de bexiga (11). 


\subsection{Aspectos anatomopatológicos de importância prognóstica no carcinoma de bexiga}

O tipo histológico mais comum de câncer de bexiga nos países desenvolvidos é o carcinoma urotelial, que compreende mais de $90 \%$ de todas as neoplasias desse órgão (12).

A definição da história natural do câncer de bexiga é de difícil caracterização pela biologia heterogênea da neoplasia. Porém, a recorrência e a progressão tumorais podem ser estimadas com base na avaliação de características histopatológicas apresentadas pelo carcinoma urotelial (13).

\section{Grau histológico}

Em dezembro de 1998, membros da Organização Mundial da Saúde (OMS) e da Sociedade Internacional de Uropatologia (ISUP) publicaram o consenso da classificação das neoplasias uroteliais da bexiga urinária, substituindo a classificação da OMS de 1973 (14). Após modificações e melhor definição das categorias, tal classificação foi oficializada como a Classificação da Organização Mundial da Saúde 2004 (OMS 2004), sendo a atualmente utilizada internacionalmente $(12,15)$.

Pela Classificação OMS 2004, as neoplasias uroteliais da bexiga urinária e suas lesões relacionadas são divididas em dois grupos:

- Carcinoma urotelial invasivo, incluindo suas variantes morfológicas;

- Neoplasias uroteliais não invasivas: carcinoma urotelial in situ (CIS), carcinoma urotelial papilífero de alto grau (CaUPAG), 
carcinoma urotelial papilífero de baixo grau (CaUPBxG), neoplasia urotelial papilífera de baixo potencial de malignidade (NUPBxPM), papiloma urotelial e papiloma urotelial invertido;

- Lesões relacionadas: displasia urotelial (neoplasia intraurotelial de baixo grau), hiperplasia urotelial, atipia urotelial reativa e atipia urotelial de significado não conhecido.

A padronização da nomenclatura e a definição das categorias das neoplasias uroteliais da bexiga permitiram determinar o grau histológico como uma ferramenta de grande importância prognóstica para a recorrência e a progressão das neoplasias, especialmente as não invasivas (16). Nas NUPBxPM, a recorrência pode ser observada em $27-37 \%$ dos casos, porém a progressão do estádio da doença não é relatada (17) . No CaUPBxG, índices de recorrência, progressão do grau e progressão do estádio são descritos em $48-71 \%, 7 \%$ e $2-12 \%$ dos casos, respectivamente (18). Entretanto, o CaUPAG demonstra um comportamento biológico distinto, onde a recorrência é observada em até $58 \%$ e a progressão do estádio em até $61 \%$ dos casos (19). Quando analisamos a sobrevida, os índices também são inversamente proporcionais ao grau histológico: 93-100\%, 82-96\% e 74-90\%, respectivamente para NPBPM, CaUPBxG e CaUPAG (18).

Em relação ao tipo histológico/configuração dos tumores vesicais, classificações adaptadas a partir da OMS também são aceitas, inclusive sugeridas no último protocolo para o exame de espécimes de pacientes com 
carcinoma da bexiga urinária, publicação recente do Colégio de Patologistas Americanos, onde a neoplasia urotelial maligna é dividida em carcinomas uroteliais papilíferos (invasivos ou não invasivos) e não papilíferos (inclui o carcinoma urotelial invasivo e suas variantes) (20).

\section{Tamanho da neoplasia e focalidade}

Quando está em questão a avaliação de tumores denominados como superficiais (não invasivos ou invasivos até lâmina própria), o tamanho e a multifocalidade do tumor estão associados com o aumento das chances de recorrência, progressão do estádio e diminuição da sobrevida média (21-22). Em uma série de 218 cistectomias, Cheng et al. também comprovaram que o tamanho do tumor $(\geq 3,0 \mathrm{~cm})$ foi um preditor independente de sobrevida câncer específica e sobrevida livre de metástase à distância de 10 anos após a cistectomia (23). Porém, esses achados geralmente são observados em associação com características morfológicas diretamente relacionadas à pior evolução dos tumores uroteliais, como o grau histológico e a presença de CIS.

\section{Padrão arquitetural de invasão tumoral}

Em um estudo com 93 casos de carcinomas uroteliais de bexiga tratados com cistectomia radical, Jimenez et al. reconheceram três principais padrões arquiteturais de invasão tumoral baseados em critérios morfológicos: tipo I - nodular, tipo II - trabecular e tipo III - infiltrativo (24). A presença do padrão infiltrativo, que se caracteriza por células arranjadas em 
cordões ou isoladas permeando o estroma no tumor, esteve associada com menor sobrevida média (29 meses), comparada com os casos que não apresentavam esse tipo de padrão (sobrevida média de 85 meses; $p=0,06$ ). Avaliando a presença desses padrões de invasão em carcinomas uroteliais do trato urinário superior, Langner et al. demonstraram que a presença do padrão infiltrativo esteve associada com menor sobrevida livre de metástase em 5 anos (12\%) quando comparada com os padrões nodular e trabecular (94\% e $74 \%$, respectivamente) (25).

\section{Variantes histológicas e diferenciações divergentes do carcinoma urotelial}

O carcinoma urotelial invasivo é reconhecido por sua capacidade de diferenciação divergente e apresentação de variantes morfológicas. A OMS reconhece como principais variantes do carcinoma urotelial: diferenciação escamosa, diferenciação glandular, ninhos, microcística, micropapilífera, linfoepitelioma-símile, linfoma-símile e plasmocitoide, sarcomatoide (com e sem elementos heterólogos), diferenciação trofoblástica, células claras e células lipídicas (12).

O reconhecimento das variantes morfológicas é de grande importância no diagnóstico diferencial com lesões não neoplásicas e com outras neoplasias malignas, incluindo o comprometimento vesical secundário por outro carcinoma ou sarcoma. A presença de uma variante morfológica está associada a comportamento biológico mais agressivo dos carcinomas uroteliais, podendo refletir inclusive na opção por 
condutas terapêuticas diferentes do uso habitual no carcinoma urotelial convencional (26).

\section{Carcinoma urotelial in situ}

Carcinoma in situ (CIS) da bexiga é uma entidade distinta, definida como um carcinoma urotelial plano não invasivo e de alto grau histológico. Estima-se que $5 \%$ a $10 \%$ dos pacientes com carcinoma superficial de bexiga apresentem CIS concomitante, aumentando as chances de progressão (27). Os estudos de história natural indicam que, nos casos sem tratamento, a progressão para doença musculoinvasiva ocorra em $54 \%$ dos pacientes (28). Em estudo envolvendo 243 pacientes submetidos à cistectomia radical por CIS como indicação clínica, Tilki et al. constataram o aumento do estádio patológico em $36 \%$ de seus casos, incluindo invasão da lâmina própria ou até o tecido extravesical e metástase em linfonodos regionais em 5,8\% dos casos (29). Alterações moleculares associadas a mutações de genes supressores tumorais (TP53, RB e PTEN) e à perda de função de proteínas reguladoras do ciclo celular são os principais eventos relacionados à origem dos CIS e a sua progressão (30-31).

\section{Invasão neoplásica linfovascular}

A invasão linfovascular (ILV), também denominada angiolinfática, é definida pela presença de células neoplásicas em espaços delineados por endotélio, podendo representar tanto um vaso sanguíneo como linfático. Sua incidência é variável, sendo relatada em até $36,4 \%$ das cistectomias de 
pacientes com carcinoma urotelial, e sua prevalência aumenta de acordo com o estádio patológico (9\% em pT1 e 77,5\% em pT4) (32). A presença da ILV em cistectomia é considerada um preditor independente de recorrência e está associada com diminuição das sobrevidas média e câncer específica em pacientes com linfonodos regionais negativos. Analisando a concordância entre a detecção de ILV em material de ressecção transuretral de tumores de bexiga (RTUTB) e em cistectomia radical, Resnick et al. demonstraram o maior risco de metástase linfonodal nos pacientes com ILV já detectada no material de RTUTB $(48,3 \%)$ quando comparados com os casos de ILV negativa (25\%) (33).

\section{Estadiamento patológico}

O estádio patológico é considerado o mais importante determinante do prognóstico e do tratamento para o câncer de bexiga (34). Em razão de tão grande importância, a classificação correta do estádio do tumor primário deve ser um objetivo constante no estudo anatomopatológico dessas neoplasias. Porém, deve-se salientar que a variabilidade interobservador quanto à definição da profundidade de invasão neoplásica é documentada, principalmente nos tumores classificados como pT1 (invasão da lâmina própria) e na determinação da infiltração da camada muscular própria (músculo detrusor) da bexiga - tumores pT2 $(18,35-36)$. 


\subsection{Principais vias moleculares relacionadas à carcinogênese urotelial}

O uso de marcadores moleculares e das suas vias de ação tem, nos últimos anos, contribuído em muito com o reconhecimento de importantes aspectos da carcinogênese urotelial, bem como no diagnóstico, prognóstico e planejamento de novas estratégias terapêuticas. Através desse entendimento, observou-se que as neoplasias uroteliais têm origem a partir de vias fenotípicas diferentes: 1) Mutação do gene do receptor 3 do fator de crescimento fibroblástico (fibroblast growth factor receptor 3 gene - FGFR3): frequentemente observada na doença papilífera/superficialmente invasiva; 2) Mutação do gene TP53: associada aos carcinomas invasivos de alto grau, são caracterizados por alterações funcionais e estruturais nas vias reguladoras do ciclo celular como p53 e pRB (37). Além disso, alterações moleculares como a deleção de ambos os braços do cromossomo 9 podem ser detectadas na maioria dos carcinomas uroteliais, sugerindo que esse seja um evento precoce na carcinogênese dessas neoplasias.

\section{A via do FGFR3}

Mais de $70 \%$ das neoplasias uroteliais papilíferas de baixo grau apresentam mutação do FGFR3. O FGFR3 é um receptor membro da família tirosina quinase relacionado com a regulação de processos celulares como crescimento, diferenciação e angiogênese. Os tumores uroteliais com mutação deste gene apresentam prognóstico favorável, pois são de baixo 
grau e raramente progridem para doença musculoinvasiva (38). O papel oncogênico da ativação do FGFR3 mutado está associado à via sinalizadora do HRAS e provavelmente resulta na ativação das vias do MAPK e/ou PI3quinase.

\section{A via do TP53 e do RB}

Assim como em grande número das neoplasias humanas, alterações estruturais e funcionais no gene supressor de tumor TP53 também são encontradas nos carcinomas uroteliais. Estudos demonstram que a mutação do TP53 é rara nos tumores papilíferos não invasivos de baixo grau, mas frequentemente é encontrada nos carcinomas invasivos de alto grau e nos CIS (30). A presença de alteração do TP53 é um dos mais importantes fatores preditivos de recorrência, progressão e sobrevida dos pacientes com carcinoma urotelial, sendo diretamente relacionado com o grau e estadiamento avançados destas lesões (39-40).

Mutações e deleções não são as únicas causas de perda de função do gene TP53, mas também alterações por mecanismos de upstream (p. ex. p14 ${ }^{A R F}$ ) ou downstream (p21 ou WAF1), que são encontrados nos carcinomas uroteliais. Outro mecanismo que envolve a perda de função do TP53 é a superexpressão da oncoproteína MDM2, que é um autorregulador da proteína p53 no ciclo celular por sequestro e degradação mediada por ubiquitinas. A superexpressão de MDM2 pode ser observada em $30 \%$ dos carcinomas uroteliais, sendo mais associada a carcinomas de alto grau (41-42). 
Alterações somáticas do produto do gene retinoblastoma (RB1) também são detectadas nos carcinomas uroteliais, principalmente nas formas mais agressivas com invasão muscular. Seja por diminuição/ausência da sua expressão ou pela superexpressão da forma proteica hiperfosforilada, em ambos os casos a função de inibir os fatores de transcrição da família E2F está comprometida, permitindo assim o aumento da proliferação celular (37).

\subsection{Microambiente tumoral e progressão do câncer}

Embora muitas pesquisas concentrem seus esforços em estudar alterações próprias das células tumorais, como mutações que resultem em ganho de oncogenes ou perda da função de genes supressores tumorais, há também diversos trabalhos que se concentram na compreensão do microambiente onde a célula cancerosa está locada não só como um figurante, mas também como um elemento principal no desenvolvimento das neoplasias (43-45). É histórica a ideia de que o microambiente exerça um papel no desenvolvimento das neoplasias malignas. O primeiro a aventar essa possibilidade foi Rudolph Virchow, em 1863, observando os leucócitos do estroma neoplásico e sugerindo a origem de neoplasias em sítios de inflamação crônica. Posteriormente, em 1889 Paget formulou a hipótese do "solo e a semente" atribuindo função aos elementos estromais. Em 1982, Bissel et al. desenvolveram a teoria moderna de que o microambiente da célula tumoral é fundamental para sua evolução (46). 
Atualmente é reconhecido que o microambiente tumoral apresenta mudanças durante o desenvolvimento e progressão do câncer. Células como os fibroblastos associados ao câncer promovem a liberação de fatores de crescimento e citocinas que podem influenciar no desenvolvimento tumoral precoce por alterar as interações normais entre célula epitelial e estromal. O microambiente tumoral pode ainda ser influenciado pela variabilidade genética intrínseca do hospedeiro, conforme demonstrado por Holliday et al., que estudaram a capacidade de fibroblastos com genótipos diferentes em promover a invasão de células de câncer de mama de acordo com a maior expressão de metaloproteinase de matriz 3 (MMP-3) (47).

A matriz extracelular (MEC) é responsável pelo suporte estrutural das células e pela transmissão de sinais através de receptores de adesão da superfície celular. É principalmente constituída por colágeno, glicoproteínas e proteoglicanos. A membrana basal é considerada como uma especialização da MEC, que separa as células epiteliais do estroma adjacente, formando a primeira barreira contra a invasão de carcinomas. Durante o processo de progressão tumoral, a MEC sofre um remodelamento que é mediado por proteinases extracelulares, particularmente as metaloproteinases de matriz, que têm como origem as células estromais (48). Atualmente sabemos que a função das MMPs não fica restrita à degradação da MEC, isso porque algumas MMPs atuam como supressores de tumor e indutores da angiogênese (49).

A hipóxia também exerce função relevante no microambiente tumoral, pois a baixa tensão de oxigênio no tecido está associada com a síntese de 
proteínas que regulam o metabolismo celular, angiogênese, proliferação celular, apoptose e remodelamento tecidual, além de aumentar a instabilidade genética celular.

O papel de células inflamatórias no microambiente, principalmente macrófagos e linfócitos, também merece destaque. $\mathrm{O}$ infiltrado de células $\mathrm{T}$ CD8+ e células dendríticas maduras está associado com prognóstico favorável no carcinoma colorretal e de cabeça-pescoço (50). Porém, uma extensa infiltração por macrófagos correlaciona-se com pior prognóstico em câncer de mama e bexiga, assim se associando a maior risco de metástases (51).

\subsubsection{Metaloproteinases de matriz extracelular - aspectos gerais}

As metaloproteinases de matriz (MMPs) são uma família de endopeptidases zinco-dependentes composta por pelo menos 21 enzimas em seres humanos, subdivididas em oito classes estruturais: cinco são secretadas e três são MMPs tipo-membrana (MT-MMP). As MMPs são sintetizadas como zimogênios inativos (pro-MMPs) que assumem a forma ativa após clivagem proteolítica. Sua atividade é regulada por inibidores endógenos, incluindo os inibidores teciduais de metaloproteinases (TIMPs).

As MMPs estão super-reguladas em muitos tipos de câncer (onde sua expressão é geralmente associada com pior evolução clínica), artrite, vasculopatias e doenças inflamatórias (52). Estudos em neoplasias mostram que algumas MMPs são expressas pela própria célula cancerosa, enquanto 
outras são sintetizadas por células do estroma tumoral, incluindo fibroblastos e células inflamatórias (53-54).

As MMPs podem promover progressão do câncer pelo aumento do crescimento celular, migração, invasão, angiogênese e metástases. Além da sua função histórica de degradar os componentes estruturais da MEC e da membrana basal, facilitando a migração celular, as MMPs podem atuar clivando proteínas ligadas a fatores de crescimento, regulando receptores tirosina quinase, moléculas de adesão celular e outras proteinases (48). Por tudo isso não devemos esquecer a sua real função no cenário no qual essas enzimas estão inseridas: a de reguladoras do microambiente, promovendo a interação estroma/célula tumoral.

\section{Metaloproteinases de matriz 2, 9 e 14}

A MMP-2 (gelatinase A ou colagenase tipo IV 72-kDa) e a MMP-9 (gelatinase B ou colagenase tipo IV 92-kDa) são enzimas da classe estrutural das gelatinases. A MMP-14 pertence à classe das transmembranas (MT1-MMP). A interação funcional entre as MMPs pode ser demonstrada pela ativação da MMP-2, que ocorre na superfície celular através de uma via envolvendo a ligação da MMP-14 ao TIMP-2, que uma vez associados se ligam à pro-MMP-2 e a transformam na forma ativa da enzima.

Como citado anteriormente, as MMPs podem ser sintetizadas tanto pelas células tumorais como pelo estroma. Analisando amostras de carcinomas uroteliais, Wallard et al. demonstraram a expressão de MMP-2 e MMP-14 no estroma neoplásico, enquanto que a MMP-9 foi detectada tanto 
no epitélio quanto no estroma (55). Em outro estudo envolvendo carcinoma de mama, Polette et al. constatam mRNA MMP-2 nos fibroblastos do estroma próximo às células tumorais, enquanto que a proteína MMP-2 foi expressa tanto no estroma como na membrana das células do carcinoma, indicando um recrutamento das MMPs estromais pelas células tumorais do fronte de invasão (56).

Entre as MMPs associadas ao carcinoma urotelial da bexiga, destacam-se a MMP-2, MMP-9 e MMP-14, por estarem relacionadas ao grau histológico e invasão tumoral. Kanayama et al. avaliaram através de RT-PCR a expressão de MMP-2, TIMP-2 e MMP-14 em 41 pacientes com câncer de bexiga e demonstraram maior expressão de MMP-2 e do seu inibidor tecidual nos tumores musculoinvasivos ou localmente avançados quando comparados com os carcinomas pTa/pT1, além da associação entre altos níveis de expressão de MMP-2, TIMP-2 e MMP-4 com diminuição da sobrevida (57). Geng et al., estudando a imunoexpressão de MMP-2 em 110 amostras de pacientes com carcinomas de bexiga pTa/pT1, constataram que níveis aumentados de MMP-2 foram relacionados com maior índice de recorrência após ressecção cirúrgica (58). Através de estudos por zimografia e imuno-histoquímica, Papathoma et al. relataram que níveis aumentados de MMP-9 e MMP-2 ativas em carcinomas uroteliais de bexiga mostraram associação significativa com o grau e a invasão tumoral, porém não se correlacionaram com a recorrência de tumores superficiais e a progressão nos tumores invasivos (59). Porém, a despeito dos resultados apresentados, ainda é discutível se a correlação entre a atividade de MMPs e seus 
inibidores séricos ou teciduais podem ser ferramentas úteis na prática médica, gerando informações sobre o prognóstico e orientando condutas terapêuticas nos pacientes com câncer de bexiga (60).

\subsubsection{Transição epitélio-mesênquima}

Alterações no fenótipo celular entre as estados epitelial e mesenquimal, definidos como transições epitélio-mesênquima e mesênquima-epitélio, são fundamentais para 0 desenvolvimento embriológico durante a gastrulação, mas também exercem importante papel na patogênese do câncer e em condições fibrosantes após lesão tecidual.

A transição epitélio-mesênquima (TE-M) é um processo complexo no qual as células epiteliais modulam o seu fenótipo perdendo suas características diferenciadas como a adesão celular, polarização e ausência de mobilidade, e adquirem características típicas de uma célula mesenquimal incluindo mobilidade, capacidade de invasão e resistência a apoptose (61-62). Durante esse processo, destaca-se a perda da função da E-caderina (responsável pela adesão intercelular do epitélio) e a superregulação de genes mesenquimais como vimentina e fibronectina. Por consequência, a TE-M está implicada na capacidade de invasão, disseminação metastática e aquisição de resistência terapêutica (63).

Múltiplos mecanismos estão envolvidos na ativação da TE-M, como as vias de sinalização celular associadas ao fator transformador de crescimento beta (TGFß) e ao Wnt, ativação constitutiva de receptores 
tirosina quinase, ativação de fatores de transcrição, integrinas, MMPs e hipóxia.

As MMPs estão associadas ao processo de TE-M de maneiras diversas, seja por degradar a membrana basal e os elementos da MEC, criando "caminhos" que facilitam a migração de células neoplásicas no estroma, ou por estimular a síntese e/ou ativar moléculas que atuam na reprogramação das células epiteliais e posterior aquisição do fenótipo mesenquimal (64-65).

No carcinoma urotelial, o fenômeno da TE-M é representado morfologicamente pela transformação sarcomatoide, onde o tumor exibe uma justaposição entre elementos epiteliais e mesenquimais. Essas neoplasias são reconhecidamente mais agressivas que as formas convencionais do carcinoma urotelial. A perda da expressão de E-caderina e o aumento de MMP-9 já foram associados à pior sobrevida câncer específica em pacientes com carcinoma urotelial, sugerindo um papel da MMP e da TE-M na progressão desse tipo de câncer (66). 


\section{OBJETIVOS}




\subsection{Objetivos gerais}

Determinar o perfil de expressão imuno-histoquímica em um painel de três enzimas de metaloproteinases de matriz (MMP-2, MMP-9 e MMP-14) em série de carcinomas uroteliais primários da bexiga, musculoinvasivos (pT2) e localmente avançados (pT3/pT4), de pacientes submetidos a cistectomia radical e linfadenectomia regional pelo grupo de Uro-oncologia do Hospital das Clínicas da Faculdade de Medicina da Universidade de São Paulo (HCFMUSP) e do Instituto do Câncer do Estado de São Paulo (ICESP).

\subsection{Objetivos específicos}

2.2.1 Caracterizar de forma detalhada a presente série de carcinomas uroteliais de bexiga com relação à distribuição das variáveis anatomopatológicas estudadas;

2.2.2 Determinar o padrão de expressão imuno-histoquímica de MMP-2, MMP-9 e MMP-14 nos tumores primários de bexiga e nas suas respectivas metástases para linfonodos regionais (quando presentes), comparando sua expressão tanto nas células do epitélio neoplásico 
como no estroma adjacente, em amostras tumorais organizadas em blocos de micromatrizes teciduais (tissue microarray - TMA);

2.2.3 Associar os achados anatomopatológicos estudados com a imunoexpressão das MMPs acima descritas, visando à melhor compreensão de aspectos relacionados à progressão do tumor, especialmente invasão e metástase para linfonodos regionais;

2.2.4 Associar o estadiamento tumoral segundo o sistema AJCC/TNM 2009 com a imunoexpressão das MMPs pesquisadas. 
3 MÉTODOS 


\subsection{Casuística}

Trata-se de um estudo retrospectivo realizado no Hospital das Clínicas da Faculdade de Medicina da Universidade de São Paulo (HCFMUSP), cuja casuística final compreendeu 61 pacientes submetidos a cistectomia radical e linfadenectomia regional pela equipe de Uro-oncologia da Divisão de Clínica Urológica do HCFMUSP e do ICESP, com o diagnóstico de carcinoma urotelial primário da bexiga urinária.

\section{Critérios de inclusão:}

a) a partir de informações disponíveis no banco de dados de trabalhos anteriores do autor e das Divisões de Anatomia Patológica e de Clínica Urológica do HCFMUSP, foram selecionados inicialmente 78 pacientes submetidos à cistectomia radical nos períodos de dezembro/2000, novembro/2004 a novembro/2005 e julho/2006 a outubro/2009;

b) disponibilidade de lâminas de histologia e blocos de parafina nos arquivos da Divisão de Anatomia Patológica do HCFMUSP: 78 pacientes;

c) diagnóstico final de carcinoma urotelial primário de bexiga e invasivo no mínimo na camada muscular própria/músculo detrusor (pT2) nos produtos das cistectomias radicais: 65 pacientes; 
d) utilização do espécime cirúrgico proveniente da ressecção transuretral do tumor de bexiga (RTUTB) previamente realizada até 75 dias antes da cistectomia radical (este critério foi utilizado devido à escassa representatividade da neoplasia residual na cistectomia após a RTUTB): 03 pacientes.

\section{Critérios de exclusão:}

a) neoplasias não invasivas nas cistectomias radicais (pTa): 02 pacientes;

b) neoplasias invasivas somente até a lâmina própria nas cistectomias radicais $(\mathrm{pT} 1)$ : 11 pacientes;

c) neoplasias exibindo total diferenciação escamosa cujo reconhecimento de um componente de carcinoma urotelial convencional fosse duvidoso: 03 pacientes;

d) neoplasias exibindo total diferenciação glandular cujo reconhecimento de um componente de carcinoma urotelial convencional fosse duvidoso: 01 paciente.

\subsection{Variáveis clínicas}

As informações referentes ao gênero, idade à cirurgia, tamanho e multifocalidade da neoplasia primária foram obtidas após revisão dos prontuários médicos, incluindo os relatórios cirúrgicos e os laudos anatomopatológicos. 
Para melhor caracterização, o tamanho da neoplasia (relatado em $\mathrm{cm}$ ) foi organizado em 11 categorias, divididas a cada $1,0 \mathrm{~cm}$ : até $1,0 \mathrm{~cm}$; $1,1-2,0 \mathrm{~cm} ; 2,1-3,0 \mathrm{~cm} ; 3,1-4,0 \mathrm{~cm} ; 4,1-5,0 \mathrm{~cm} ; 5,1-6,0 \mathrm{~cm} ; 6,1-7,0 \mathrm{~cm}$; 7,1 - 8,0 cm; 8,1 - 9,0 cm; 9,1-10,0 cm; > 10,0 cm. Quando multifocal, foi considerado o tamanho do maior foco neoplásico.

Visando a análise estatística, adicionalmente os casos foram condensados em 2 grupos a partir do tamanho mediano obtido da casuística $(4,0 \mathrm{~cm})$, compondo uma categoria denominada tamanho tumoral agrupado.

\subsection{Variáveis anatomopatológicas}

Cortes histológicos obtidos de blocos de parafina e corados com hematoxilina \& eosina foram submetidos à revisão histopatológica (Anexo A). Foram avaliadas as seguintes variáveis anatomopatológicas:

- Grau histológico: classificado em baixo grau ou alto grau, conforme a classificação da OMS 2004 para as neoplasias uroteliais $(12,15)$;

- Tipo/configuração da neoplasia: tendo como base a classificação da OMS 2004, foi definido para este trabalho o tipo/configuração da neoplasia como papilífero e não papilífero (sólido), visto que na prática diária da uropatologia cirúrgica a observação desses padrões é constante. Adicionamos também uma terceira categoria 
que inclui as formas mistas do carcinoma urotelial, quando essas duas configurações estão presentes na mesma neoplasia;

- Porcentagem do tipo papilífero: a presença do tipo papilífero da neoplasia foi caracterizada de forma semiquantitativa em 11 categorias, em intervalos a cada 10\% (zero/ausência de tumor papilífero; 1 - 10\%; $11-20 \% ; 21-30 \% \ldots 91-100 \%$ da neoplasia);

- Porcentagem do tipo papilífero agrupada: baseado no valor mediano da casuística para essa variável histológica (40\%), o tipo papilífero da neoplasia foi estudado também sob a forma condensada em 2 grupos, obedecendo como ponto de corte de $40 \%$ (carcinomas uroteliais com até $40 \%$ e com mais de $40 \%$ do tipo papilífero constituindo a neoplasia);

- Padrão arquitetural de invasão tumoral: Adaptando os padrões de invasão tumoral descritos por Jimenez et al. (24) aos principais padrões que encontramos na rotina diagnóstica, classificamos nossa casuística em 6 grupos: 1) nodular (predomínio de ninhos celulares bem delimitados em mais de $50 \%$ da neoplasia, com diâmetros variados mas sempre arredondados, mesmo nas áreas mais profundas do tumor); 2) trabecular (trabéculas com pelo menos 3 colunas de células, geralmente anastomosantes, em mais de $50 \%$ da neoplasia); 3) infiltrativo (cordões e células isoladas, geralmente associados com desmoplasia, necrose e pleomorfismo nuclear, constituindo no mínimo $50 \%$ da neoplasia); 4) misto, 
trabecular e infiltrativo (predomínio dos dois padrões arquiteturais, onde cada um represente menos de $50 \%$ do tumor); 5) misto, trabecular e nodular (predomínio dos dois padrões arquiteturais, onde cada um represente até $50 \%$ do tumor); 6) misto, infiltrativo e nodular (predomínio dos dois padrões arquiteturais, onde cada um represente menos de $50 \%$ do tumor);

- Atipia nuclear: avaliando características nucleares como tamanho, presença de nucléolo evidente, distribuição de cromatina, irregularidade da membrana nuclear e pleomorfismo, a atipia nuclear foi classificada em leve, moderada ou intensa;

- Componente sarcomatoide: carcinoma sarcomatoide é considerado como uma variante do carcinoma urotelial invasivo caracterizado como uma neoplasia maligna bifásica exibindo evidências morfológicas e/ou imuno-histoquímicas de diferenciações epitelial e mesenquimal, com ou sem a presença de elementos heterólogos. No presente estudo, o componente sarcomatoide foi histologicamente reconhecido como uma neoplasia maligna de alto grau com células fusiformes e/ou células indiferenciadas, sendo determinada como presente ou ausente;

- Porcentagem do componente sarcomatoide: devido a observações de nossa prática diária da anatomia patológica, percebemos que o componente sarcomatoide pode se apresentar em pequenas quantidades ou mesmo de forma significativa nos 
carcinomas uroteliais. Por isso, no presente estudo, caracterizamos de forma semiquantitativa em 12 categorias essa variável patológica, em intervalos a cada 10\% (zero/ausência de componente sarcomatoide; $1-5 \%$ ou focal; $6-10 \% ; 11-20 \% ; 21$ $-30 \% \ldots 91-100 \%$ da neoplasia);

- Diferenciação escamosa: determinada como presente ou ausente, foi histologicamente reconhecida como a evidência de queratinização ou pontes intercelulares que caracterizam a diferenciação escamosa;

- Porcentagem de diferenciação escamosa: caracterizada de forma semiquantitativa em 11 categorias, em intervalos a cada $10 \%$ (zero/ausência de diferenciação escamosa; 1 - 10\%; 11 - 20\%; 21 $-30 \% \ldots 91-100 \%$ da neoplasia);

- Diferenciação glandular: determinada como presente ou ausente, foi definida pelo encontro de espaços glandulares verdadeiros dentro da neoplasia. Foram assim incluídas tanto as glândulas na forma tubular quanto entérica com secreção de mucina;

- Porcentagem de diferenciação glandular: caracterizada de forma semiquantitativa em 11 categorias, em intervalos a cada $10 \%$ (zero/ausência de diferenciação glandular; 1 - 10\%; 11 - 20\%; 21 $30 \% \ldots 91-100 \%$ da neoplasia); 
- Variante histológica: Além das diferenciações escamosa, glandular e sarcomatoide, foram ainda registradas as seguintes variantes reconhecidas pela classificação da OMS 2004 e por publicações prévias $(26,67)$ : variante formadora de ninhos, microcística, micropapilífera, padrão invertido, células pequenas, células claras (citoplasma rico em glicogênio), linfoepitelioma-símile, linfomasímile e plasmocitoide, com células gigantes, diferenciação trofoblástica, células lipídicas, características rabdoides, estroma pseudossarcomatoso e outras formas de reação estromal não usual. No presente trabalho, além da presença ou ausência da variante histológica, também foi caracterizado o tipo morfológico da variante quando esteve presente;

- Carcinoma urotelial in situ (CIS): reconhecido como presente ou ausente, dependendo do achado morfológico de uma neoplasia intraurotelial plana de alto grau histológico, seja na mucosa adjacente à neoplasia ou na mucosa distante do tumor principal;

- Invasão neoplásica linfovascular (angiolinfática): determinada como presente ou não identificada, a depender da ocorrência de células tumorais localizadas no interior de espaços vasculares reconhecidamente revestidos por endotélio ao exame histológico convencional, circundados por camada muscular lisa no caso de infiltração vascular venosa; 
- Invasão neoplásica perineural: determinada como presente ou não identificada, dependendo do encontro de blocos celulares neoplásicos ou células tumorais isoladas acometendo o perineuro de forma parcial ou circunferencialmente, ou ainda infiltrando o feixe neural;

- Estádio patológico do tumor principal AJCC/TNM: definido como a profundidade máxima da infiltração tumoral, realizado segundo a última classificação AJCC $7^{\text {a }}$ edição - TNM 2009 (68): pT2a - infiltração da muscular própria superficial/metade interna pT2b - infiltração da muscular própria profunda/metade externa pT3a - infiltração do tecido perivesical microscópico pT3b - infiltração do tecido perivesical macroscópico (massa extravesical)

pT4a - infiltração do estroma prostático, vesículas seminais, útero, vagina

pT4b - infiltração da parede pélvica, parede abdominal

- Estádio patológico tumoral agrupado pT2 versus pT3+pT4: foram agrupados os casos de doença musculoinvasiva (pT2) versus doença localmente avançada (pT3+pT4);

- Estádio patológico tumoral agrupado pT2+pT3 versus pT4: outra forma de agrupamento aqui analisada compreendeu a comparação entre o conjunto de neoplasias infiltrativas na 
muscular própria (pT2) e no tecido perivesical (pT3) versus os casos de invasão de órgãos adjacentes (pT4);

- Metástase para linfonodo regional: determinada como ausente, presente ou não se aplica (sem linfadenectomia). Seguindo a última edição do Manual para estadiamento de câncer da AJCC, foram consideradas cadeias de linfonodos regionais para os carcinomas de bexiga: hipogástrica, obturadora, ilíaca (interno e externo), pélvica perivesical, sacral, pré-sacral e ilíaca comum (68);

- Tamanho da maior metástase linfonodal: a medida do maior diâmetro da maior metástase linfonodal foi estimada utilizando uma régua para uso em microscopia óptica, cujos intervalos são divididos a cada $0,05 \mathrm{~mm}$. A presença de células tumorais nos linfonodos foi classificada de acordo com o sistema utilizado de rotina na avaliação dos carcinomas de mama: células tumorais isoladas (até $0,2 \mathrm{~mm}$ ); micrometástase $(0,2 \mathrm{~mm}-2,0 \mathrm{~mm}$ ); macrometástase (maior que 2,0 mm) (68);

- Extensão neoplásica extranodal: determinada como ausente, presente ou não se aplica (sem linfadenectomia). Foi definida como comprometimento neoplásico além da cápsula linfonodal, com infiltração dos tecidos adiposo e conjuntivo perilinfonodais. 


\subsection{Construções das micromatrizes teciduais (TMA)}

Durante a reavaliação das secções histológicas coradas pela hematoxilina \& eosina, o autor demarcou em cada lâmina áreas de interesse para posterior confecção dos blocos de TMA, selecionando as áreas mais representativas do tumor primário e da metástase em linfonodo regional.

Conforme método descrito por Konnonen et al. (69), e utilizando equipamento MTA1 (Manual Tissue Microarrayer, Beecher Instruments, EUA), foram confeccionados blocos de TMA com agulhas de 1,0 milímetro de diâmetro para extração dos cilindros teciduais dos blocos doadores, que foram dispostos nos blocos receptores com espaçamento de 0,3 milímetro, procedimentos realizados no LIM-14, Patologia Hepática, FMUSP. Para efeito de orientação de posição, na primeira linha horizontal e nas primeiras três posições da primeira coluna foram dispostos tecidos renais controles obtidos de necropsia. Os blocos receptores foram confeccionados com parafina Histosec em pastilhas (Merck, EUA).

Com vistas a minimizar as perdas parciais físicas e/ou de representatividade inerentes à tecnologia de TMA, cada caso do tumor primário da cistectomia radical foi representado quatro vezes, sendo duas amostras da área de maior grau histológico e outras duas amostras da área de maior profundidade de invasão neoplásica do tumor, organizadas em dois blocos receptores. Para avaliação da metástase no linfonodo regional, foram obtidas duas amostras do carcinoma metastático no tecido linfonodal, organizadas em um bloco receptor. 
Por se tratar de sistema de orientação matricial, previamente à confecção dos blocos elaborou-se planilha em Excel (Microsoft Office 2003, EUA) designando para cada posição o respectivo caso contido com a finalidade de posterior registro dos resultados.

Visando a evitar perdas decorrentes da necessidade de se aparar o bloco de parafina, cada bloco foi submetido a sessão única de microtomia, com a utilização de um micrótomo Leica em cortes de $3 \mu \mathrm{m}$. Foi obtida, por bloco de TMA, média de 50 secções que foram dispostas em lâminas silanizadas, submetidas a banho de parafina e arquivadas em caixa escura em freezer $-20^{\circ} \mathrm{C}$, visando a preservação da antigenicidade das amostras conforme descrito por DiVito et al. (70).

\subsection{Estudos imuno-histoquímicos}

Os procedimentos imuno-histoquímicos foram realizados em conjunto no LIM-14/FMUSP e no Laboratório de imuno-histoquímica do Instituto Adolfo Lutz, sob coordenação da farmacêutica Alda Wakamatsu.

\subsubsection{Anticorpos primários utilizados e padronização dos ensaios}

Para detecção in situ das MMPs estudadas pelo método imunohistoquímico $(\mathrm{IH})$, foram utilizados os seguintes anticorpos primários, com a 
seguinte titulação selecionada a partir de estudos-piloto de otimização para as condições laboratoriais:

- MMP-2: Anticorpo monoclonal de camundongo, Clone CA4001/CA719E3C; Abcam. Título 1:50.

- MMP-9: Anticorpo monoclonal de camundongo, Clone 56-2A4; Abcam. Título 1:100.

- MMP-14: Anticorpo monoclonal de coelho, clone EP1264Y; Abcam. Título 1:400.

Para os ensaios $\mathrm{IH}$, as lâminas seccionadas a partir do bloco de parafina de TMA foram desparafinizadas e reidratadas. $O$ bloqueio da peroxidase endógena foi obtido utilizando $\mathrm{H}_{2} \mathrm{O}_{2} 6 \%$. Bloqueio de proteína foi obtido com CASBlock TM (Invitrogen/Zymed). Recuperação antigênica com ácido cítrico 10mM em pH 6,0 foi necessária nos anticorpos MMP-9 e MMP-14. A incubação com anticorpo primário foi efetuada inicialmente por 30 minutos a $37^{\circ} \mathrm{C}$, seguindo-se passagem para geladeira a $4^{\circ} \mathrm{C}$ por 16 horas ("overnight"). A amplificação do sinal foi baseada no uso de peroxidase acoplada a polímeros pequenos de dextrana, livres de complexos avidinabiotina (Novolink, Novocastra, RU). A revelação da reação foi feita com peróxido de hidrogênio e diaminobenzidina como cromógeno. Controles positivos representados por placenta humana, bem como controles negativos estabelecidos por omissão da fase de incubação com o anticorpo primário, foram usados em cada reação. 


\subsubsection{Interpretação dos resultados das reações imuno-histoquímicas - análise da reatividade}

Para cada amostra comprovada como adequada para avaliação nos cortes de TMA, referentes ao tumor primário ou à metástase linfonodal, foram analisadas (Anexo B):

i) Positividade da reação - A extensão/quantidade da reação em uma determinada amostra tecidual foi caracterizada de forma semiquantitativa, como negativa ou positiva (de 1 a $100 \%$, em intervalos de 10\%), resultando em 11 categorias: 0 (zero); $1(1-10 \%) ; 2(11-20 \%) ; 3(21-30 \%) ; 4(31-40 \%) ; 5(41-50 \%) ;$

$6(51-60 \%) ; 7(61-70 \%) ; 8(71-80 \%) ; 9$ (81-90\%); $10(91-100 \%)$

ii) Intensidade da reação - Caracterizada em 3 categorias: 0 (zero); 1 (fraca); 2 (forte/intensa);

iii) Cálculo do escore da reação - Baseado em modelo de avaliação semiquantitativa publicado por McCarty et al. em 1985, denominado Histochemical score ("HSCORE"), que avaliou a expressão IH do receptor de estrogênio em carcinomas de mama através da combinação da intensidade e distribuição da reação (71), propusemos para este estudo um método semelhante, porém não idêntico, de avaliação IH semiquantitativa das MMPs, que foi denominado de escore e pode variar de zero (ausência de reatividade) até 20 (maior reatividade). O valor obtido desse 
escore representa o produto da positividade pela intensidade da reação, utilizando os números atribuídos a cada categoria [Escore $(0-20)=$ Positividade $(0-10) \times$ Intensidade $(0-2)]$.

As avaliações das expressões IH de cada MMP foram realizadas de três formas diferentes no tumor primário:

i) Expressão global na neoplasia: compreendendo o epitélio tumoral e o estroma;

ii) Expressão apenas no epitélio tumoral: avaliação das células epiteliais que constituem o carcinoma urotelial;

iii) Expressão apenas no estroma tumoral: avaliação das células mesenquimais adjacentes às células do carcinoma.

Nos casos de metástase linfonodal, a avaliação da expressão das MMPs foi realizada de forma global (em conjunto no epitélio e estroma) nos depósitos tumorais do linfonodo acometido.

Essa avaliação foi realizada pelo autor em cada amostra de tecido disponível a partir dos cortes obtidos dos blocos de TMA. Para os cálculos finais foram considerados os maiores escores, ou seja, o resultado de maior expressão de MMP de cada caso (cada tumor), que tenha sido obtido no spot de maior grau histológico ou de maior profundidade de infiltração neoplásica. 


\subsection{Análise estatística}

As variáveis clínicas e anatomopatológicas foram comparadas com a imunoexpressão de MMP-2, MMP-9 e MMP-14 nos tumores primários e nas metástases linfonodais usando o teste qui-quadrado de Pearson $\left(x^{2}\right)$ e considerando significantes valores dos níveis descritivos de probabilidade $(p)$ menores que $\alpha=0,05(p<0,05)$. O programa de análise estatística utilizado foi SPSS, versão 13.0 (SPSS Inc, Chicago, EUA), com apoio do Dr. Kleber Simões do Espírito Santo. 
4 RESULTADOS 
Todos os dados referentes a cada caso (tabela-fonte) são expostos nos Anexos C, D, E e F.

O texto do presente capítulo expõe o conjunto dos dados, sendo os achados com associação estatística significativa $(p<0,05)$ ou com tendência a tal associação $(0,05<p<0,1)$ analisados mais detalhadamente mediante confecção de tabelas.

\subsection{Características clínico-patológicas}

Dos 61 pacientes que compõem a série de casos usada para o presente estudo, 51 são do gênero masculino $(83,6 \%)$ e 10 do gênero feminino (16,4\%), com razão M:F de 5,1:1. A idade mínima na cirurgia foi de 40 anos e a máxima de 84 anos, sendo a média de 65,4 \pm 10,9 anos (média \pm D.P.), com a mediana de 67 anos.

O tamanho do tumor primário variou de 1,0 a $12,0 \mathrm{~cm}$, sendo a média $4,3 \pm 2,2 \mathrm{~cm}$ (média \pm D.P.) e a mediana $4,0 \mathrm{~cm}$. A distribuição do tamanho tumoral de acordo com as categorias propostas nos métodos do trabalho foi: até 1,0 cm: 1 caso; $1,1-2,0 \mathrm{~cm}: 8 ; 2,1-3,0 \mathrm{~cm}: 13 ; 3,1-4,0 \mathrm{~cm}: 10$; 4,1 - 5,0 cm: 9; 5,1-6,0 cm: 10; 6,1 - 7,0 cm: 5; 7,1-8,0 cm: 1; 8,1 - 9,0 cm: 2; $>10 \mathrm{~cm}$ : 1 caso. Os tumores medindo até $4,0 \mathrm{~cm}$ foram observados em 
32 casos $(53,3 \%)$ e, os maiores que $4,0 \mathrm{~cm}$, em 28 casos $(46,7 \%)$. Em um caso, não havia a informação disponível sobre o tamanho da neoplasia nos relatórios médicos revisados.

Todos os 61 casos foram classificados com alto grau histológico, segundo a OMS 2004. Em relação à focalidade do tumor primário, 51 foram unifocais $(83,6 \%)$ e 10 multifocais $(16,4 \%)$. Pelo tipo/configuração da neoplasia, 1 caso $(1,6 \%)$ foi classificado como papilífero, $34(55,7 \%)$ como não papilíferos e $26(42,7 \%)$ como mistos. A porcentagem do tipo papilífero obedeceu a distribuição a seguir: ausência do tipo papilífero: 34 casos $(55,7 \%) ; 1-10 \%: 6$ casos $(9,8 \%) ; 11-20 \%: 3(4,9 \%) ; 21-30 \%: 5(8,2 \%)$; 31 - 40\%: 3 (4,9\%); 51 - 60\%: 1 (1,6\%); 61 - 70\%: 1 (1,6\%); 81 - 90\%: $6(9,8 \%)$; 91 - 100\%: 2 (3,3\%). A porcentagem agrupada do padrão papilífero foi distribuída da seguinte forma: ausência do tipo papilífero: 34 casos (55,7\%), 1 - 40\% do tipo papilífero: 17 casos (27,9\%), >40\% do tipo papilífero: 10 casos $(16,4 \%)$.

A avaliação do padrão arquitetural de invasão tumoral mostrou que 3 casos $(4,9 \%)$ foram classificados como nodulares; $7(11,5 \%)$ como trabeculares; $13(21,3 \%)$ como infiltrativos; $33(54,1 \%)$ do tipo misto, infiltrativo e trabecular; 5 casos $(8,2 \%)$ como mistos, nodulares e trabeculares. A atipia nuclear foi classificada como moderada em 16 casos $(26,2 \%)$ e intensa em 45 casos $(73,8 \%)$, não sendo detectados casos com atipia leve.

O componente sarcomatoide foi observado em 9 casos $(14,8 \%)$, sendo detectado em até $5 \%$ do tumor em 1 caso $(1,6 \%)$, de 6 a $10 \%$ em 
2 casos (3,3\%), $11-20 \%$ em 1 caso (1,6\%), $21-30 \%$ em 1 caso $(1,6 \%)$, $81-90 \%$ em 2 casos (3,3\%) e $91-100 \%$ em 2 casos (3,3\%). Cinquenta e dois casos $(85,2 \%)$ não apresentaram componente sarcomatoide como um elemento do tumor primário.

A diferenciação escamosa foi constatada em 8 casos $(13,1 \%)$, sendo que em 6 deles $(9,8 \%)$ a área escamosa representava até $10 \%$ do tumor, 1 caso $(1,6 \%)$ até $20 \%$ e outro único caso $(1,6 \%)$ até $30 \%$ do tumor primário. A diferenciação glandular foi identificada em 6 casos $(9,8 \%)$, sendo que em 3 casos $(4,9 \%)$ a área glandular constituiu até $10 \%$ do tumor primário, 2 casos $(3,3 \%)$ até $20 \%$ e 1 caso $(1,6 \%)$ até $60 \%$ da neoplasia.

Em 13 pacientes $(21,3 \%)$ da casuística, houve a presença de alguma variante histológica do carcinoma urotelial. A subestratificação dessa categoria demonstrou que a variante formadora de ninhos foi a mais prevalente, com 4 casos $(6,6 \%)$, seguida das variantes micropapilífera (3 casos, 4,9\%), células claras/ricas em glicogênio (3 casos, 4,9\%), células pequenas ( 1 caso, 1,6\%), padrão invertido (1 caso, 1,6\%) e linfoepiteliomasímile ( 1 caso, 1,6\%).

Ao exame histológico convencional em secções coradas por hematoxilina \& eosina, a invasão neoplásica linfovascular pôde ser identificada em 48 casos $(78,7 \%)$. Estruturas neurais foram evidenciadas como comprometidas pela neoplasia em 38 casos $(62,3 \%)$. O componente de carcinoma urotelial in situ foi observado em 28 casos $(45,9 \%)$.

O estadiamento patológico do tumor primário (AJCC/TNM 2009) nas cistectomias radicais apresentou a seguinte distribuição: pT2a - 1 caso 
(1,6\%), pT2b - 11 casos (18\%), pT3a - 19 casos $(31,1 \%)$, pT3b -16 casos $(26,2 \%)$ e pT4a - 14 casos $(23 \%)$. As neoplasias estadiadas como doença musculoinvasivas (pT2) corresponderam a 12 casos $(19,7 \%)$, e aquelas classificadas como doença localmente avançada (pT3 + pT4) somaram 49 $\operatorname{casos}(80,3 \%)$.

A linfadenectomia regional foi realizada em 57 dos 61 pacientes. Metástases para linfonodos regionais foram detectadas em 34 casos (59,6\%), sendo 2 casos classificados como micrometástase $(3,5 \%)$ e 32 como macrometástase $(56,1 \%)$. Dos 34 casos positivos para doença metastática, a extensão neoplásica extranodal esteve presente em 14 casos e ausente em 20. Não foram observados depósitos tumorais menores que $0,2 \mathrm{~mm}$ (células tumorais isoladas) nos produtos de linfadenectomia.

Fotomicrografias exemplificando os aspectos morfológicos do tumor primário (figuras 1 a 4) e da metástase linfonodal (figura 5) são expostas a seguir. 

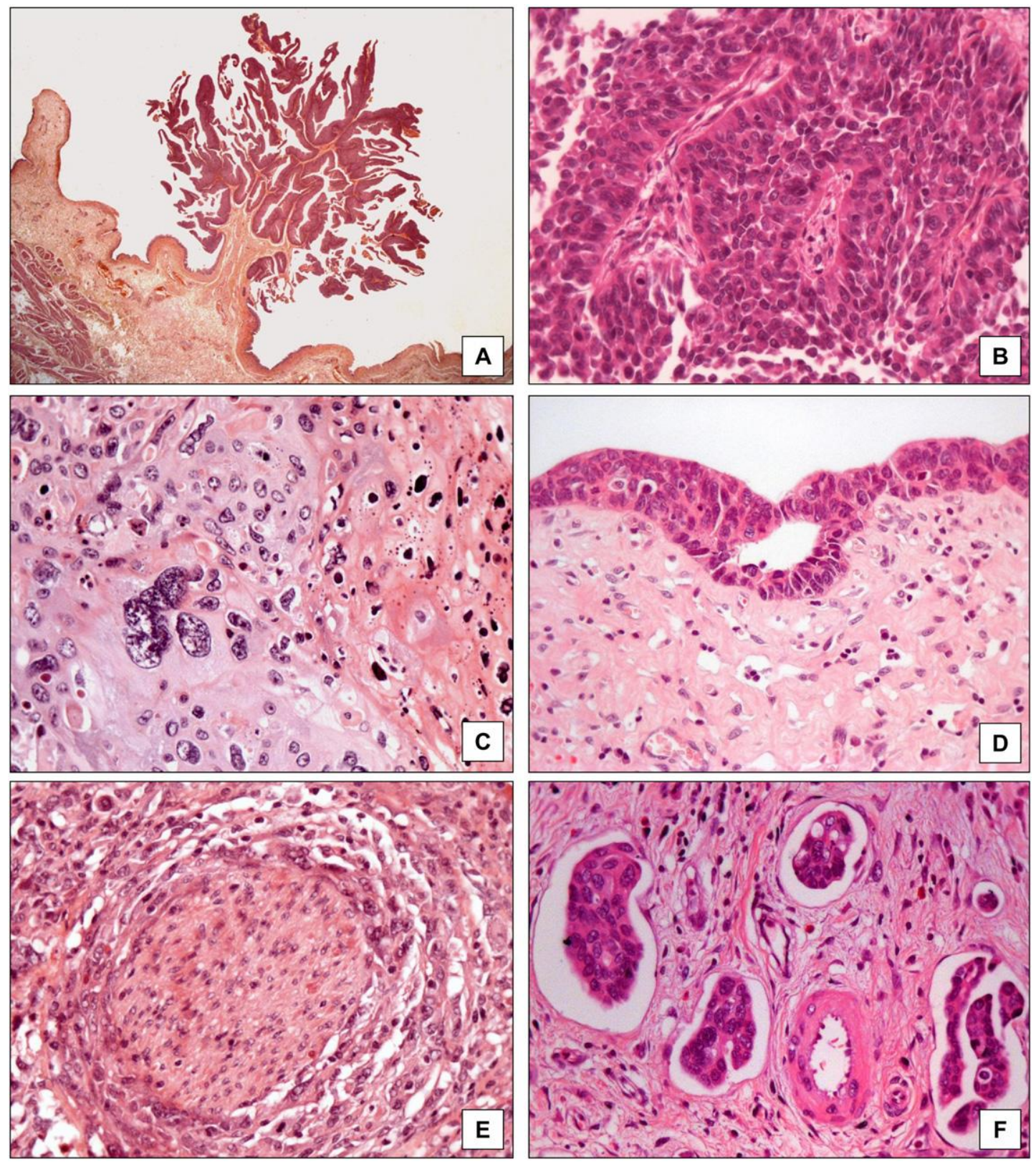

Figura 1. Aspectos morfológicos do carcinoma urotelial de bexiga. A- Lesão multifocal, segundo foco observado adjacente ao tumor principal (HE, 12,5x); B- Alto grau histológico (HE, 400x); C- Atipia nuclear intensa (HE, 400x); D- Carcinoma in situ (HE, 400x); E- Infiltração perineural (HE, 400x); F- Infiltração linfovascular (HE, 400x) 

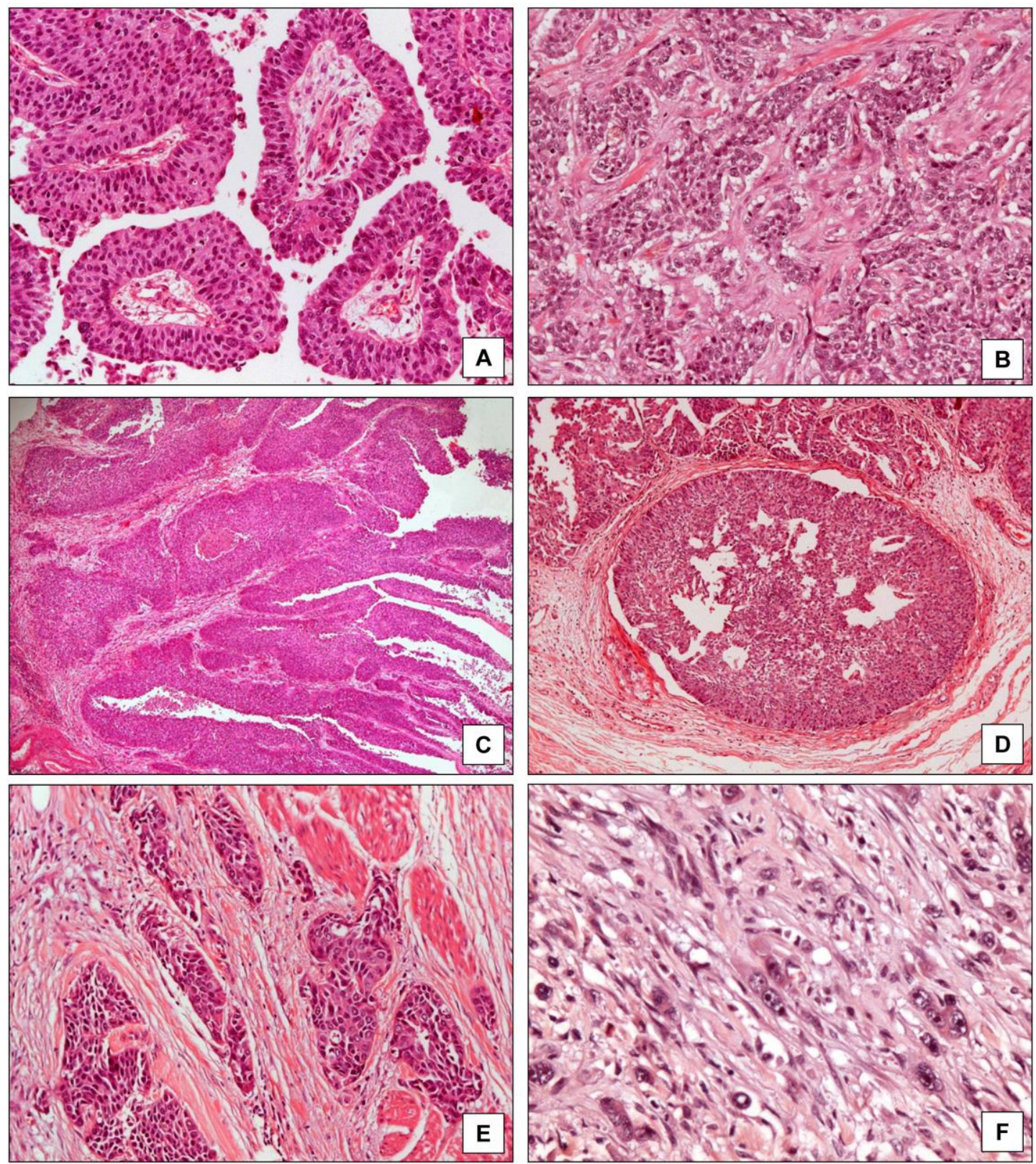

Figura 2. Tipo/configuração da neoplasia e padrões arquiteturais de invasão tumoral. A- Tipo papilífero (HE, 200x); B- Tipo não papilífero/sólido (HE, 200x); C- Tipo misto (HE, 50x); D- Padrão arquitetural nodular de invasão tumoral (HE, 100x); E- Padrão arquitetural trabecular (HE, 200x); F- Padrão arquitetural infiltrativo (HE, 400x) 

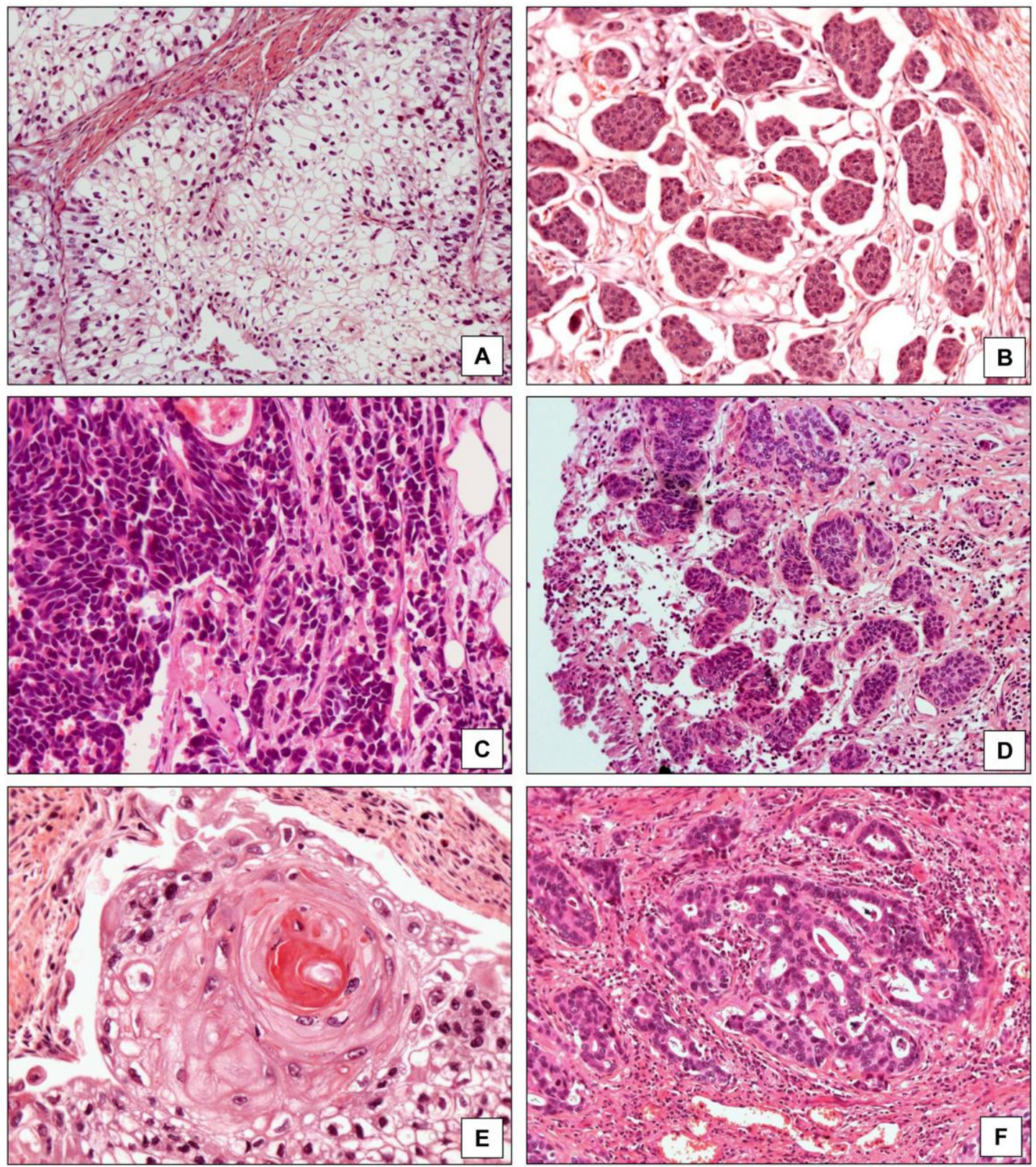

Figura 3. Variantes histológicas (A-D) e diferenciações divergentes do carcinoma urotelial de bexiga $(E / F)$. A- Células claras/ricas em glicogênio (HE, 200x); B- Micropapilífera (HE, 200x); C- Células pequenas (HE, 400x); D- Formadora de ninhos (HE, 200x); E- Diferenciação escamosa (HE, 400x);

F- Diferenciação glandular (HE, 200x) 

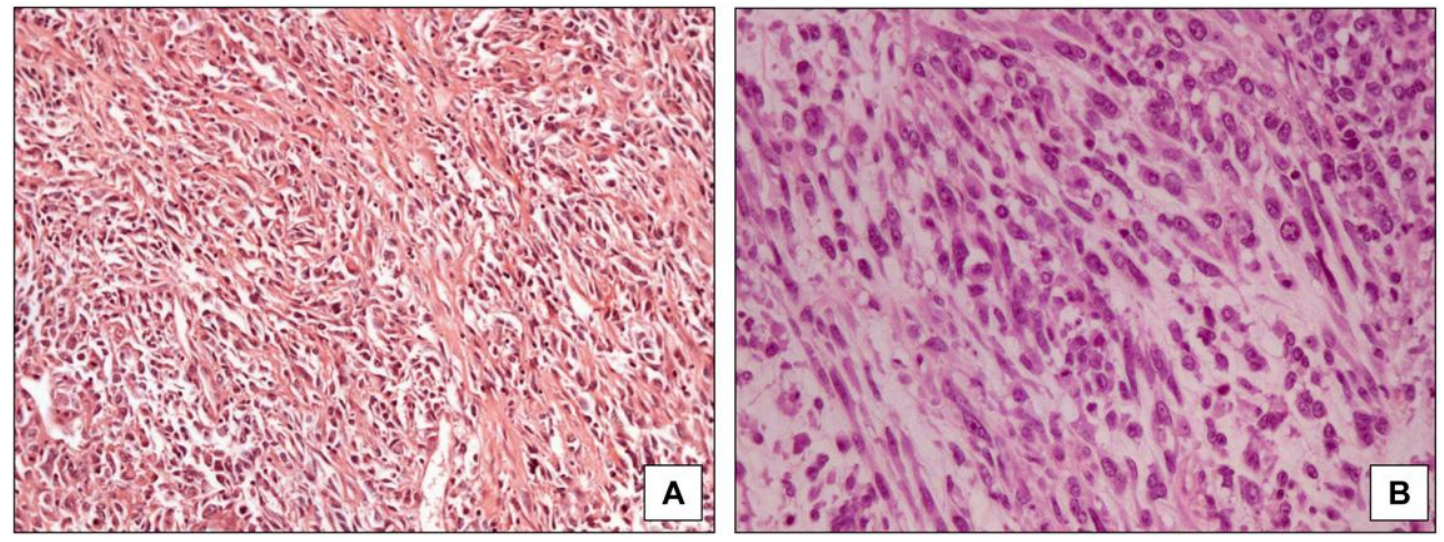

Figura 4. Componente sarcomatoide do carcinoma urotelial de bexiga (HE, A- 200x, B- 400x)
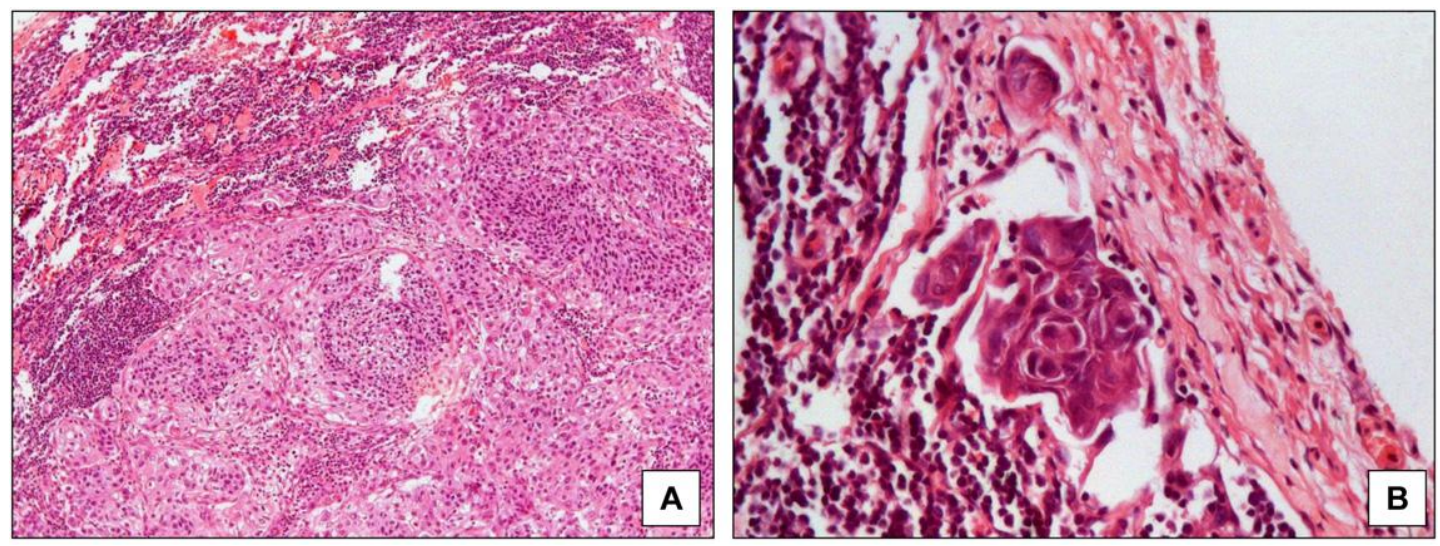

Figura 5. Metástase em linfonodo regional. A- Macrometástase (HE, 200x), B- Micrometástase (HE, 400x) 


\subsection{Avaliação imuno-histoquímica da expressão das metaloproteinases de matriz extracelular no tumor primário e na metástase linfonodal}

Ao início deste relato, importa salientar o índice de aproveitamento do TMA, tecnologia empregada no desenvolvimento desse estudo, considerando a amostragem de 4 áreas diferentes do tumor primário e 2 áreas da metástase linfonodal. Da casuística completa de 61 casos, a avaliação da expressão IH de MMP-2, MMP-9 e MMP-14 no tumor primário foi realizada em 61,60 e 60 casos, respectivamente, refletindo um índice de aproveitamento do TMA de 100\% para MMP-2, 98\% para MMP-9 e $98 \%$ para MMP-14. Para as metástases linfonodais que somaram 34 casos, foram avaliáveis 32 casos para MMP-2 (aproveitamento de 94\%), 31 casos para MMP-9 (91\%) e 30 casos para MMP-14 (88\%).

Conforme descrito na seção de Métodos do trabalho, o cálculo do escore é um produto da avaliação da positividade e da intensidade da imunoexpressão na amostra tecidual. A seguir estão descritos os valores obtidos nas reações IH para avaliação das MMPs.

\subsubsection{Expressão imuno-histoquímica de MMP-2 no tumor primário}

A positividade global da expressão IH de MMP-2 no tumor primário foi detectada em 36 casos (59\%), sendo 23 casos (37,7\%) em até $10 \%$ da amostra, 8 casos positivos até $20 \%$ e 5 casos positivos até $30 \%$ da 
amostra. Em 25 casos (41\%) o resultado foi negativo. Dentre os 36 casos positivos, a intensidade da reação foi estimada como fraca em 28 casos e forte em 8 casos.

Considerando a expressão de MMP-2 apenas no epitélio neoplásico, 31 casos $(50,8 \%)$ mostraram-se positivos, com 18 casos apresentando uma positividade em até $10 \%$ das células epiteliais, 8 casos até $20 \%$ do epitélio e 5 casos com positividade estimada em até $30 \%$. Trinta casos $(49,2 \%)$ foram negativos. A intensidade da imunorreatividade de MMP-2 nas células epiteliais tumorais foi avaliada como fraca em 25 casos (41\%) e forte em outros 6 casos.

Com relação à expressão de MMP-2 no estroma tumoral, resultados positivos foram obtidos em 22 dos 61 casos (26\%). Em 21 casos a positividade foi observada em até $10 \%$ das células estromais e em 1 caso até $30 \%$. A intensidade da reação foi considerada como fraca em 20 casos e forte nos outros 2 casos.

Após a avaliação da positividade e intensidade da reação nas amostras disponíveis, foi calculado o escore para cada compartimento neoplásico estudado. Os resultados obtidos para o escore global, o epitélio tumoral e o estroma estão demonstrados na tabela 1, salientando-se o predomínio de valores de escore classificados como 1 ou 2. 
Tabela 1 - Distribuição da frequência do escore global, no epitélio neoplásico e no estroma da imunoexpressão de MMP-2 no tumor primário

\begin{tabular}{c|cccccc}
\hline \hline & \multicolumn{7}{c}{ MMP-2 - Tumor primário } \\
\hline \multirow{2}{*}{ Escore } & \multicolumn{7}{c}{ Global } & \multicolumn{2}{c}{ Epitélio neoplásico } & \multicolumn{2}{c}{ Estroma } \\
& $\mathbf{n}$ & $\%$ & $\mathbf{n}$ & $\%$ & $\mathbf{n}$ & $\%$ \\
\hline 0 & 25 & 41 & 30 & 49,2 & 39 & 63,9 \\
1 & 18 & 29,5 & 15 & 24,6 & 19 & 31,1 \\
2 & 12 & 19,7 & 10 & 16,4 & 2 & 3,3 \\
3 & 3 & 4,9 & 3 & 4,9 & 1 & 1,6 \\
4 & 1 & 1,6 & 1 & 1,6 & - & - \\
6 & 2 & 3,3 & 2 & 3,3 & - & - \\
\hline \hline TOTAL & 61 & 100 & 61 & 100 & 61 & 100 \\
\hline
\end{tabular}

\subsubsection{Expressão imuno-histoquímica de MMP-2 na metástase linfonodal}

Dos 34 casos com metástase para linfonodo regional, a expressão de MMP-2 na neoplasia metastática foi avaliável em 32 casos (em 2 casos não havia neoplasia representativa nos cortes de TMA).

Dos 32 casos válidos, 20 (62,5\%) apresentaram positividade na metástase linfonodal e $12(37,5 \%)$ foram negativos. Em 10 casos (31,3\%) a positividade da expressão de MMP-2 foi observada em até $10 \%$ da metástase, 4 casos $(12,5 \%)$ até $20 \%, 2$ casos $(6,3 \%)$ até $30 \%$, outros 2 casos $(6,3 \%)$ em $40 \%$, em 1 caso $(3,1 \%)$ até $50 \%$ e outro único caso $(3,1 \%)$ até $80 \%$ da amostra. Dos 20 casos positivos, a intensidade da reação foi classificada como fraca em 17 e forte em 3 casos. 
Ressaltamos aqui que os 2 casos classificados como micrometástase estiveram representados nos cortes de TMA para a pesquisa de MMP-2 no linfonodo. Em ambos a reação resultou negativa.

A tabela 2 apresenta os escores observados nas metástases linfonodais. Houve predomínio do escore 1 nas metástases. Entretanto, uma maior frequência de escores elevados foram observados aqui, quando comparadas com os escores do tumor primário.

Tabela 2 - Distribuição da frequência do escore da imunoexpressão de MMP-2 na metástase linfonodal

\begin{tabular}{c|ccccccccc|c}
\hline & \multicolumn{8}{|c|}{ Escore MMP-2 na metástase linfonodal } & \multirow{2}{*}{ TOTAL } \\
Frequência & $\mathbf{0}$ & $\mathbf{1}$ & $\mathbf{2}$ & $\mathbf{3}$ & $\mathbf{4}$ & $\mathbf{5}$ & $\mathbf{6}$ & $\mathbf{8}$ & $\mathbf{n}(\%)$ \\
$\mathrm{n}$ & 12 & 10 & 3 & 1 & 2 & 1 & 1 & 2 & 32 \\
$\%$ & 37,5 & 31,3 & 9,4 & 3,1 & 6,3 & 3,1 & 3,1 & 6,3 & 100 \\
\hline \hline
\end{tabular}

Fotomicrografias exemplificando a imunoexpressão de MMP-2 no tumor primário e na metástase linfonodal são apresentadas na figura 6 . 

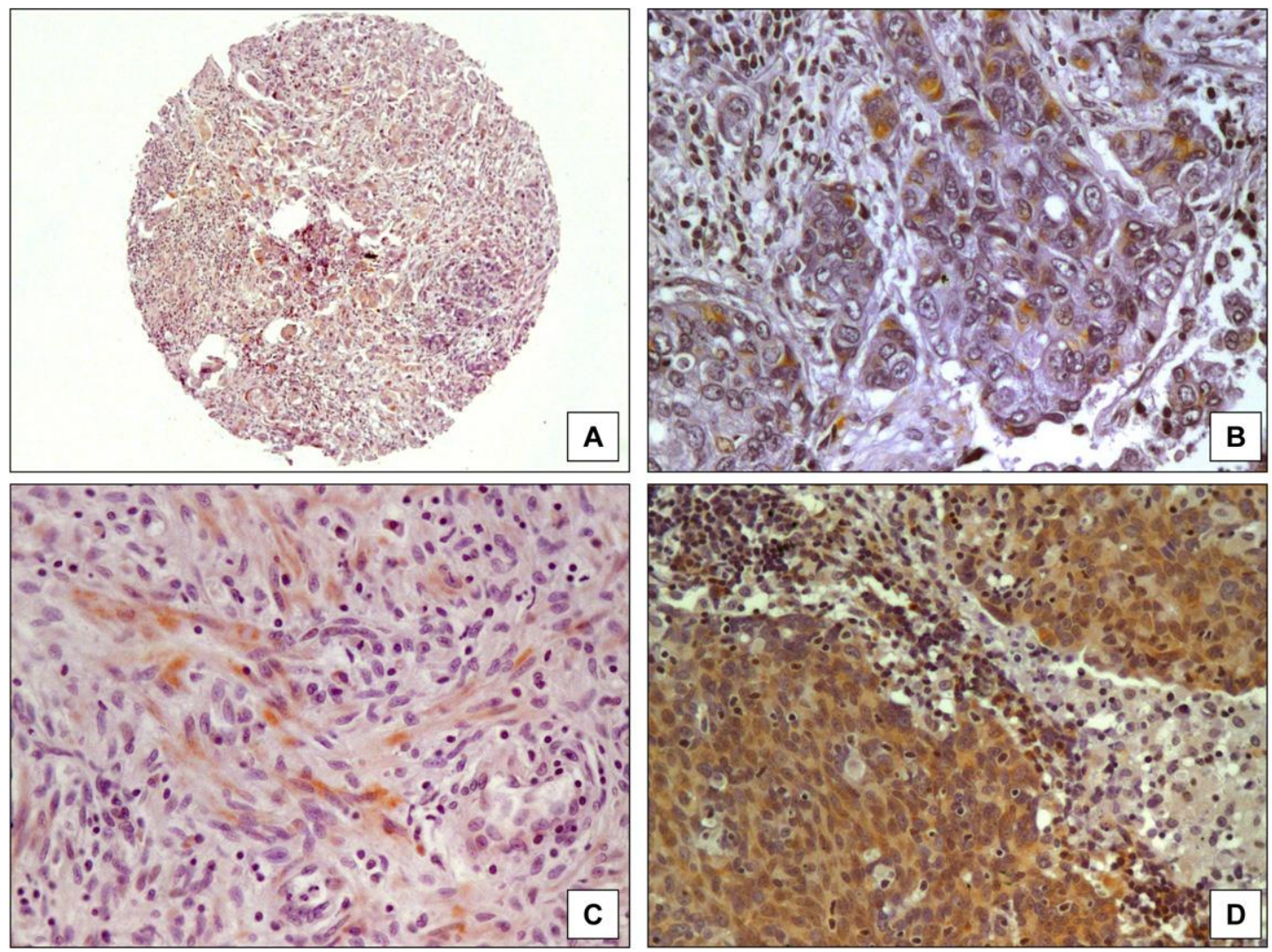

Figura 6. Expressão imuno-histoquímica de MMP-2. A- Imunoexpressão global no tumor primário (100x); B- Imunoexpressão no epitélio neoplásico (400x); C- Imunoexpressão no estroma do tumor (400x); D- Avaliação da imunoexpressão na metástase linfonodal (400x)

\subsubsection{Expressão imuno-histoquímica de MMP-9 no tumor primário}

Dos 60 casos avaliáveis para MMP-9, a positividade global da expressão IH no tumor primário foi detectada em 57 casos (95\%), sendo 14 casos $(23,3 \%)$ em até $10 \%$ da amostra, 4 casos $(6,7 \%)$ positivos até $20 \%$, 8 casos $(13,3 \%)$ até $30 \%, 6$ casos $(10 \%)$ até $40 \%, 7$ casos $(11,7 \%)$ até $50 \%$, 6 casos $(10 \%)$ até $60 \%, 4$ casos $(6,7 \%)$ até $70 \%, 6$ casos $(10 \%)$ até $80 \%$ e 2 casos $(3,3 \%)$ positivos em até $90 \%$ da amostra. Em 3 casos $(5 \%)$ o resultado foi negativo. Dos 57 casos positivos, a intensidade da reação foi classificada como fraca em 32 casos e forte em 25 casos. 
Avaliando a expressão de MMP-9 apenas no epitélio neoplásico, 51 casos $(85 \%)$ resultaram positivos, sendo 9 casos $(15 \%)$ com positividade em até $10 \%$ das células epiteliais tumorais, 3 casos (5\%) até $20 \%$, 8 casos $(13,3 \%)$ até $30 \%, 7$ casos $(11,7 \%)$ até $40 \%, 6$ casos $(10 \%)$ até $50 \%$, outros 6 casos $(10 \%)$ até $60 \%, 4$ casos $(6,7 \%)$ até $70 \%, 6$ casos $(10 \%)$ até $80 \%$ e em 2 casos $(3,3 \%)$ até $90 \%$ do epitélio tumoral. Em 9 casos (15\%), a expressão IH de MMP-9 resultou negativa no epitélio neoplásico. A intensidade da imunoexpressão de MMP-9 nas células epiteliais tumorais foi avaliada como fraca em 38 casos e forte em outros 13 casos.

Com relação à expressão de MMP-9 no estroma tumoral, resultados positivos foram observados em 52 dos 60 casos (86,7\%). Em 21 casos (35\%) a positividade foi observada em até $10 \%$ das células estromais, em 11 casos $(18,3 \%)$ até $20 \%, 7$ casos $(11,7 \%)$ até $30 \%, 8$ casos $(13,3 \%)$ até $40 \%, 4$ casos $(6,7 \%)$ até $50 \%$ e em 1 caso $(1,7 \%)$ até $60 \%$ do estroma tumoral. Em 8 casos (13,3\%), a reação para MMP-9 no estroma resultou negativa. Em relação à intensidade da expressão de MMP-9 no estroma, em 27 casos foi classificada como fraca e em 25 casos como forte.

A partir dos valores obtidos para a positividade e a intensidade da reação nas amostras disponíveis, foi calculado o escore para cada compartimento neoplásico. Os resultados do escore global, no epitélio tumoral e no estroma relativos à expressão $\mathrm{IH}$ de MMP-9, estão demonstrados na tabela 3 , onde observa-se que o escore 1 foi o mais frequentemente observado. Entretanto, houve uma ampla distribuição dos valores, incluindo escores altos. 
Tabela 3 - Distribuição da frequência do escore global, no epitélio neoplásico e no estroma da imunoexpressão de MMP-9 no tumor primário

\begin{tabular}{|c|c|c|c|c|c|c|}
\hline \multicolumn{7}{|c|}{ MMP-9 - Tumor primário } \\
\hline \multirow[b]{2}{*}{ Escore } & \multicolumn{2}{|c|}{ Global } & \multicolumn{2}{|c|}{ Epitélio neoplásico } & \multicolumn{2}{|c|}{ Estroma } \\
\hline & $\mathbf{n}$ & $\%$ & $\mathbf{n}$ & $\%$ & $\mathbf{n}$ & $\%$ \\
\hline 0 & 3 & 5 & 9 & 15 & 8 & 13,3 \\
\hline 1 & 14 & 23,3 & 9 & 15 & 19 & 31,7 \\
\hline 2 & 3 & 5 & 3 & 5 & 7 & 11,7 \\
\hline 3 & 4 & 6,7 & 8 & 13,3 & 2 & 3,3 \\
\hline 4 & 4 & 6,7 & 5 & 8,3 & 6 & 10 \\
\hline 5 & 3 & 5 & 6 & 10 & 1 & 1,7 \\
\hline 6 & 6 & 10 & 3 & 5 & 5 & 8,3 \\
\hline 7 & 2 & 3,3 & 3 & 5 & - & - \\
\hline 8 & 4 & 6,7 & 3 & 5 & 8 & 13,3 \\
\hline 10 & 4 & 6,7 & - & - & 3 & 5 \\
\hline 12 & 4 & 6,7 & 3 & 5 & 1 & 1,7 \\
\hline 14 & 2 & 3,3 & 1 & 1,7 & - & - \\
\hline 16 & 5 & 8,3 & 5 & 8,3 & - & - \\
\hline 18 & 2 & 3,3 & 2 & 3,3 & - & - \\
\hline TOTAL & 60 & 100 & 60 & 100 & 60 & 100 \\
\hline
\end{tabular}

\subsubsection{Expressão imuno-histoquímica de MMP-9 na metástase linfonodal}

A expressão IH de MMP-9 na neoplasia metastática foi avaliável em 31 casos (em 3 casos houve perda de representatividade tecidual nos cortes de TMA).

Dos 31 casos avaliáveis, $27(87,1 \%)$ demonstraram expressão positiva de MMP-9 nas metástases linfonodais, enquanto que 4 casos $(12,9 \%)$ foram negativos. A positividade da reação obedeceu à seguinte distribuição: 4 casos $(12,9 \%)$ em até $10 \%$ da amostra do carcinoma 
metastático, 3 casos $(9,7 \%)$ até $20 \%, 2$ casos $(6,5 \%)$ até $30 \%, 4$ casos $(12,9 \%)$ até $40 \%, 3$ casos $(9,7 \%)$ até $50 \%, 1$ caso $(3,2 \%)$ até $60 \%, 2$ casos $(6,5 \%)$ até $70 \%, 5$ casos $(16,1 \%)$ até $80 \%$ e 3 casos $(9,7 \%)$ até $90 \%$ da metástase. Dentre os 27 casos positivos para MMP-9 na metástase linfonodal, a intensidade foi considerada como fraca em 18 casos e forte nos outros 9 casos. Dos 2 casos classificados como micrometástase, apenas um deles apresentou representatividade nos cortes de TMA para a pesquisa de imunoexpressão de MMP-9 no linfonodo, que neste caso resultou negativa.

A tabela 4 apresenta o escore para MMP-9 observado nas metástases linfonodais. Observa-se uma distribuição relativamente homogênea, com escores baixos a altos nas metástases.

Tabela 4 - Distribuição da frequência do escore da imunoexpressão de MMP-9 na metástase linfonodal

\begin{tabular}{c|cccccccccccccc}
\hline \hline \multirow{2}{*}{ Frequência } & \multicolumn{10}{c|}{} & \multirow{1}{*}{ TOTAL } \\
& $\mathbf{0}$ & $\mathbf{1}$ & $\mathbf{2}$ & $\mathbf{3}$ & $\mathbf{4}$ & $\mathbf{5}$ & $\mathbf{6}$ & $\mathbf{8}$ & $\mathbf{9}$ & $\mathbf{1 0}$ & $\mathbf{1 4}$ & $\mathbf{1 6}$ & $\mathbf{1 8}$ & $\mathbf{n}(\%)$ \\
$\mathrm{n}$ & 4 & 4 & 3 & 2 & 3 & 2 & 1 & 3 & 1 & 1 & 2 & 3 & 2 & 31 \\
$\%$ & 12,9 & 12,9 & 9,7 & 6,5 & 9,7 & 6,5 & 3,2 & 9,7 & 3,2 & 3,2 & 6,5 & 9,7 & 6,5 & 100 \\
\hline \hline
\end{tabular}

Fotomicrografias demonstrando a imunoexpressão de MMP-9 no tumor primário e na metástase linfonodal são apresentadas na figura 7 . 

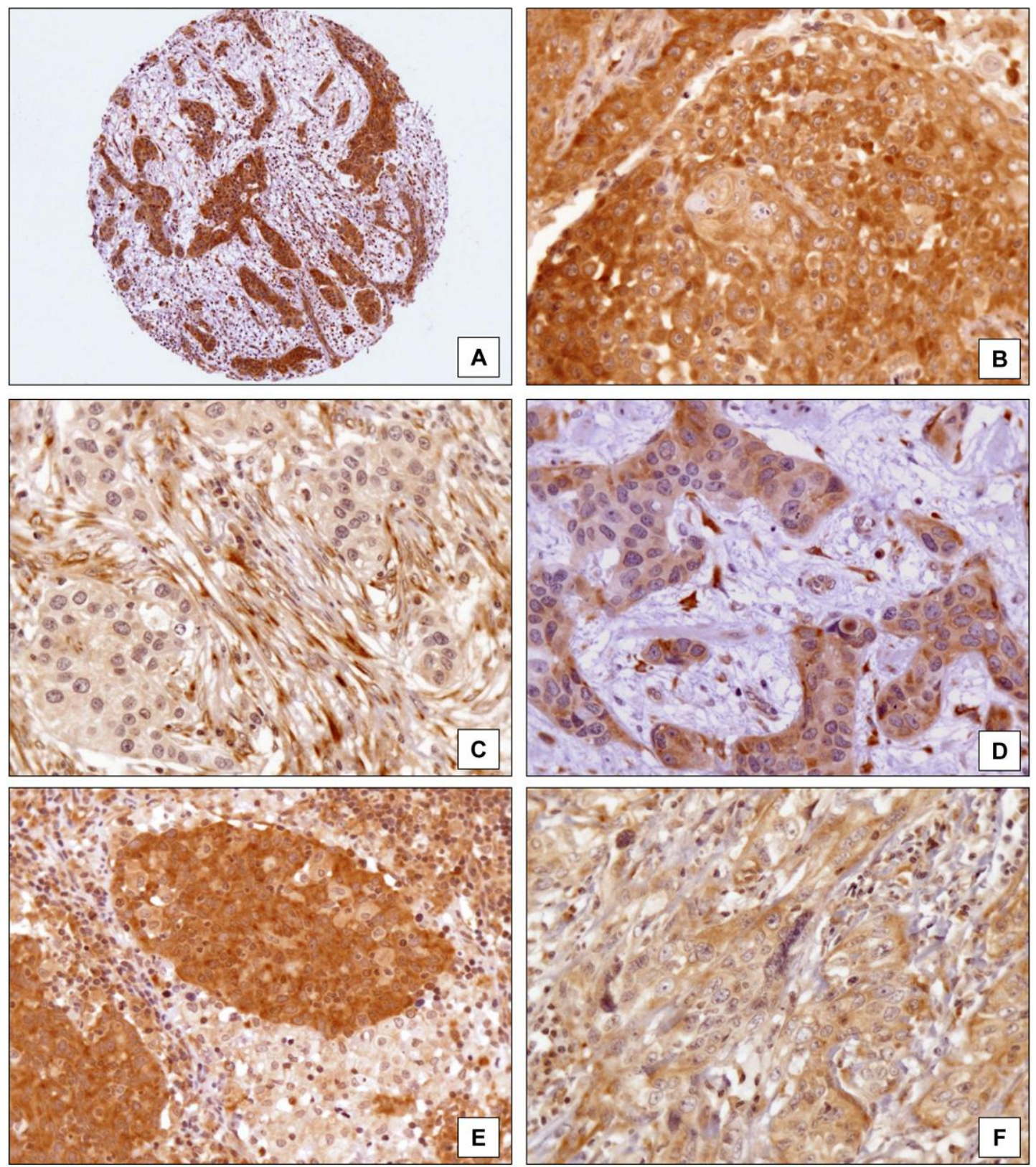

Figura 7. Expressão imuno-histoquímica de MMP-9. A- Imunoexpressão global no tumor primário (100x); B- Imunoexpressão no epitélio neoplásico (400x); C- Imunoexpressão no estroma do tumor (400x); D- Detalhe da imunoexpressão no epitélio e no estroma (400x); E- Avaliação da imunoexpressão na metástase linfonodal (400x); F- Área tumoral com atipia nuclear intensa (400x). Continua a seguir, 

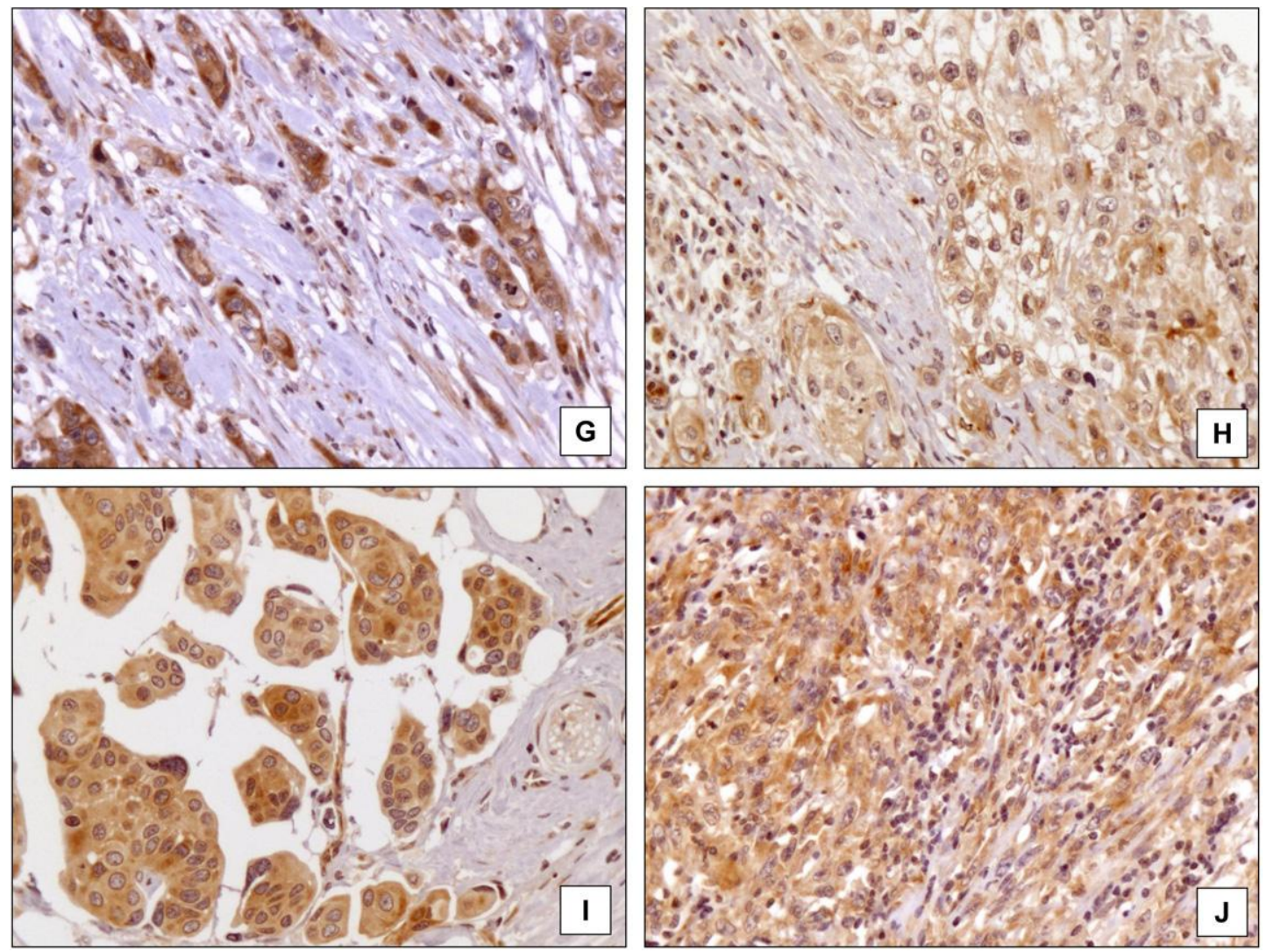

Figura 7 continuação. Expressão imuno-histoquímica de MMP-9. GImunoexpressão no tumor com padrão arquitetural infiltrativo (400x); H- Área de diferenciação escamosa (400x); I- Variante histológica micropapilífera (400x); J- Imunoexpressão no componente sarcomatoide (400x)

\subsubsection{Expressão imuno-histoquímica de MMP-14 no tumor primário}

Dos 60 casos válidos para avaliação de MMP-14, a positividade global da imunoexpressão no tumor primário foi detectada em todos os casos. A positividade da reação apresentou a seguinte distribuição: 3 casos (5\%) com positividade em até $10 \%$ da amostra, 9 casos $(15 \%)$ até $20 \%$, 10 casos $(16,7 \%)$ positivos até $30 \%, 5$ casos $(8,3 \%)$ até $40 \%, 6$ casos $(10 \%)$ até $50 \%, 9$ casos $(15 \%)$ até $60 \%, 5$ casos $(15 \%)$ até $70 \%, 8$ casos $(13,3 \%)$ 
até $80 \%$ e 5 casos $(8,3 \%)$ até $90 \%$ da neoplasia. A intensidade foi avaliada como fraca em 26 casos $(43,3 \%)$ e forte em 34 casos $(56,7 \%)$.

Considerando o epitélio neoplásico, a reação para a MMP-14 resultou positiva em 59 casos (98,3\%), sendo que em 8 casos (13,3\%) a positividade da imunoexpressão foi observada em até $10 \%$ das células epiteliais, 7 casos $(11,7 \%)$ até $20 \%, 8$ casos $(13,3 \%)$ até $30 \%, 3$ casos $(5 \%)$ até $40 \%, 6$ casos (10\%) até $50 \%, 9$ casos $(15 \%)$ até $60 \%, 5$ casos $(8,3 \%)$ até $70 \%, 8$ casos $(13,3 \%)$ até $80 \%$ e 5 casos $(8,3 \%)$ em até $90 \%$ das células epiteliais do carcinoma. Em apenas 1 caso $(1,7 \%)$ não foi detectada imunoexpressão de MMP-14 no epitélio neoplásico. A intensidade da reação foi classificada como fraca em 34 casos e forte em 25 dos 59 casos positivos.

No estroma tumoral, a imunoexpressão de MMP-14 resultou positiva em 58 casos $(96,7 \%)$ e negativa em outros 2 casos (3,3\%). Avaliando a positividade, 16 casos $(26,7 \%)$ apresentaram uma imunoexpressão em até $10 \%$ do estroma tumoral, 10 casos $(16,7 \%)$ em até $20 \%, 11$ casos $(18,3 \%)$ até $30 \%, 9$ casos $(15 \%)$ até $40 \%, 7$ casos $(11,7 \%)$ até $50 \%, 1$ caso $(1,7 \%)$ até $60 \%$, outro único caso $(1,7 \%)$ até $70 \%, 2$ casos $(3,3 \%)$ até $80 \%$ e 1 caso $(1,7 \%)$ até $90 \%$ do estroma. A intensidade da imunoexpressão foi considerada fraca em 31 casos e forte em 27 casos.

Considerando os valores obtidos para positividade e intensidade da imunoexpressão de MMP-14, foi calculado o escore global, no epitélio tumoral e no estroma do tumor primário. Os valores referentes à expressão IH de MMP-14 estão demonstrados na tabela 5, onde se observa um predomínio de escores mais elevados no epitélio tumoral, quando comparado com o estroma. 
Tabela 5 - Distribuição da frequência do escore global, no epitélio neoplásico e no estroma da imunoexpressão de MMP-14 no tumor primário

\begin{tabular}{c|cccccc}
\hline \hline \multirow{2}{*}{ Escore } & \multicolumn{6}{c}{ MMP-14 - Tumor primário } \\
\cline { 2 - 7 } & $\mathbf{n}$ & $\%$ & $\mathbf{n}$ & $\%$ & $\mathbf{n}$ & $\%$ \\
\hline 0 & - & - & 1 & 1,7 & 2 & 3,3 \\
1 & 3 & 5 & 8 & 13,3 & 13 & 21,7 \\
2 & 9 & 15 & 7 & 11,7 & 12 & 20 \\
3 & 7 & 11,7 & 6 & 10 & 7 & 11,7 \\
4 & 1 & 1,7 & 2 & 3,3 & 1 & 1,7 \\
5 & 2 & 3,3 & 3 & 5 & 1 & 1,7 \\
6 & 5 & 8,3 & 6 & 10 & 5 & 8,3 \\
7 & - & - & 1 & 1,7 & - & - \\
8 & 5 & 8,3 & 3 & 5 & 9 & 15 \\
9 & 1 & 1,7 & 1 & 1,7 & - & - \\
10 & 4 & 6,7 & 3 & 5 & 6 & 10 \\
12 & 7 & 11,7 & 5 & 8,3 & - & - \\
14 & 5 & 8,3 & 4 & 6,7 & 1 & 1,7 \\
16 & 7 & 11,7 & 6 & 10 & 2 & 3,3 \\
18 & 4 & 6,7 & 4 & 6,7 & 1 & 1,7 \\
\hline TOTAL & 60 & 100 & 60 & 100 & 60 & 100 \\
\hline \hline
\end{tabular}

\subsubsection{Expressão imuno-histoquímica de MMP-14 na metástase linfonodal}

A expressão IH de MMP-14 na neoplasia metastática foi avaliável em 30 casos (em 4 casos não havia tecido representativo nos cortes de TMA).

Dos 30 casos disponíveis, $26(86,7 \%)$ foram positivos para imunoexpressão de MMP-14 na metástase e 4 casos (13,3\%) resultaram negativos. A positividade da reação foi observada em 4 casos $(13,3 \%)$ em até $10 \%$ da metástase, em 6 casos $(20 \%)$ até $20 \%, 2$ casos $(6,7 \%)$ até $30 \%$, 3 casos (10\%) até $40 \%, 6$ casos $(20 \%)$ até $50 \%, 2$ casos $(6,7 \%)$ até $60 \%$, 
2 casos $(6,7 \%)$ até $70 \%$ e 1 caso $(3,3 \%)$ até $80 \%$ da metástase. Dentre os 26 casos positivos, a imunoexpressão foi considerada como fraca em 20 casos e forte nos outros 6 casos. Avaliando os 2 casos classificados como micrometástase, apenas um demonstrou representatividade nos cortes de TMA para a pesquisa de imunoexpressão de MMP-14 no linfonodo, que assim como nas outras MMPs também resultou negativa. A tabela 6 mostra a distribuição do escore para MMP-14 nas metástases linfonodais.

Tabela 6 - Distribuição da frequência do escore da imunoexpressão de MMP-14 na metástase linfonodal

\begin{tabular}{|c|c|c|c|c|c|c|c|c|c|c|c|c|c|}
\hline \multirow[t]{2}{*}{ Frequência } & \multicolumn{12}{|c|}{ Escore MMP-14 na metástase linfonodal } & \multirow{2}{*}{$\begin{array}{c}\text { TOTAL } \\
\text { n (\%) }\end{array}$} \\
\hline & 0 & 1 & 2 & 3 & 4 & 5 & 6 & 8 & 10 & 12 & 14 & 16 & \\
\hline $\mathrm{n}$ & 4 & 4 & 6 & 2 & 2 & 5 & 1 & 1 & 1 & 1 & 2 & 1 & 30 \\
\hline$\%$ & 13,3 & 13,3 & 20 & 6,7 & 6,7 & 16,7 & 3,3 & 3,3 & 3,3 & 3,3 & 6,7 & 3,3 & 100 \\
\hline
\end{tabular}

Fotomicrografias exemplificando a imunoexpressão de MMP-14 no tumor primário e na metástase linfonodal são apresentadas na figura 8. 

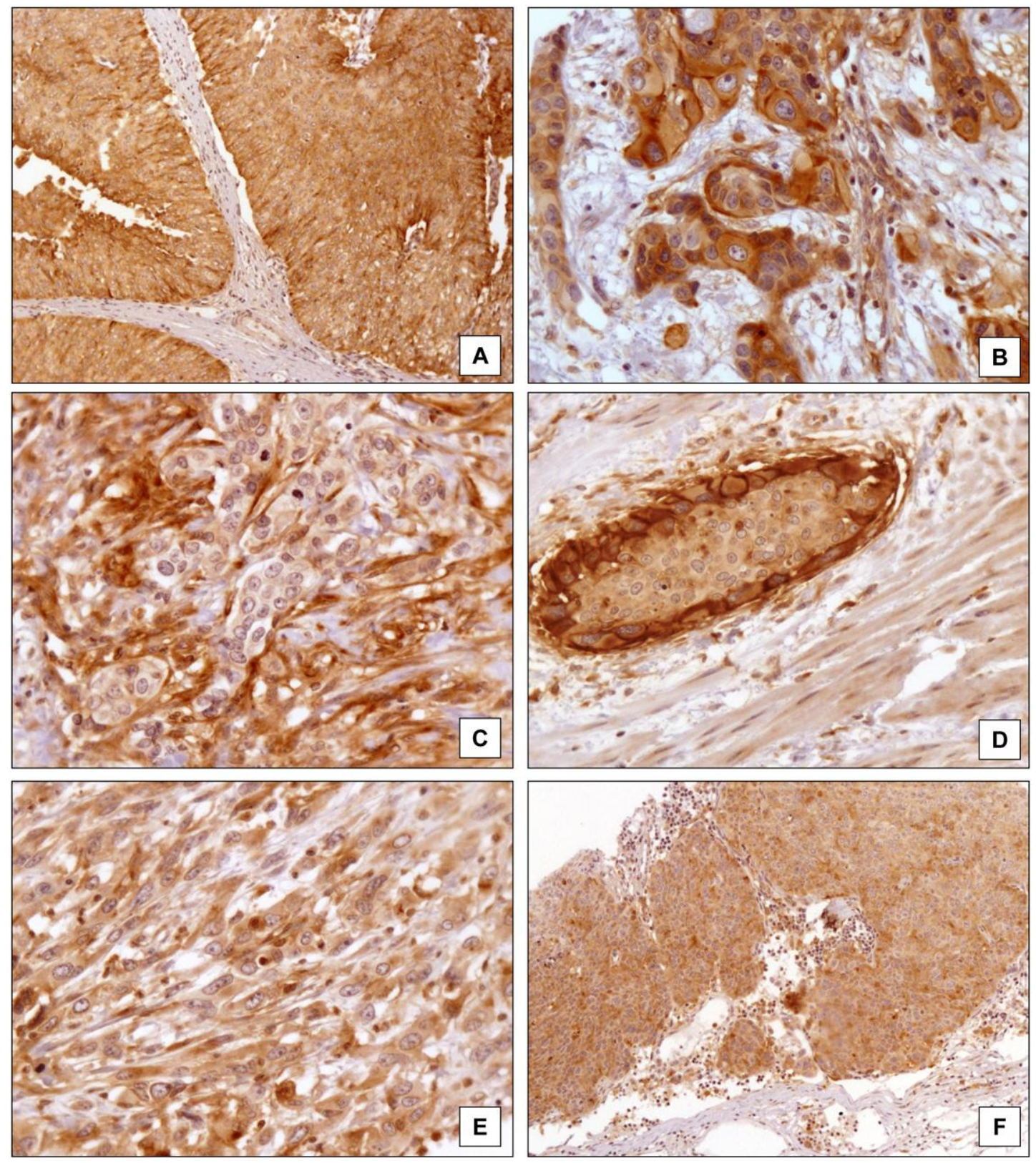

Figura 8. Expressão imuno-histoquímica de MMP-14. A- Imunoexpressão global no tumor primário (200x); B- Imunoexpressão no epitélio neoplásico (400x); C- Imunoexpressão no estroma do tumor (400x); D- Detalhe da maior reatividade da reação na interface do epitélio com o estroma (400x); E- Expressão no componente sarcomatoide (400x); F- Avaliação da imunoexpressão na metástase linfonodal (200x) 


\subsection{Análise das associações entre as variáveis anatomopatológicas e os perfis de reatividade das metaloproteinases de matriz MMP-2, MMP-9 e MMP-14}

\subsubsection{Súmula das associações entre as características} anatomopatológicas e o escore para a imunoexpressão de MMP-2

Para maior facilidade na comparação das diversas associações entre as características anatomopatológicas estudadas e a imunoexpressão de MMP-2 no tumor primário e nas metástases linfonodais, uma súmula das significâncias (p) é apresentada na tabela 7. 
Tabela 7 - Sumário das significâncias das associações entre as variáveis anatomopatológicas e o escore para MMP-2 $(p<0,05)$

\begin{tabular}{|c|c|c|c|c|}
\hline \multicolumn{5}{|c|}{ MMP-2 } \\
\hline \multirow{3}{*}{ Variáveis anatomopatológicas } & \multicolumn{4}{|c|}{ Escore $(p)$} \\
\hline & \multicolumn{3}{|c|}{ Tumor primário } & \multirow[b]{2}{*}{$\begin{array}{l}\text { Metástase } \\
\text { linfonodal }\end{array}$} \\
\hline & Global & $\begin{array}{l}\text { Epitélio } \\
\text { neoplásico }\end{array}$ & Estroma & \\
\hline Tamanho da neoplasia & 0,586 & 0,66 & 0,852 & 0,95 \\
\hline Tamanho tumor agrupado $(4,0 \mathrm{~cm})$ & 0,259 & 0,438 & 0,392 & 0,46 \\
\hline Focalidade & 0,923 & 0,923 & 0,671 & 0,921 \\
\hline Grau histológico & - & - & - & - \\
\hline Tipo/configuração da neoplasia & 0,866 & 0,924 & 0,801 & 0,07 \\
\hline Porcentagem de padrão papilífero & 0,933 & 0,989 & 0,999 & 0,994 \\
\hline Porcentagem de padrão papilífero agrupado (40\%) & 0,411 & 0,527 & 0,695 & 0,441 \\
\hline Padrão arquitetural de invasão tumoral & 0,022 & 0,005 & 0,718 & 0,916 \\
\hline Atipia nuclear & 0,497 & 0,436 & 0,032 & 0,259 \\
\hline Componente sarcomatoide & 0,27 & 0,13 & 0,062 & 0,254 \\
\hline Porcentagem de componente sarcomatoide & 0,328 & 0,177 & 0,003 & 0,432 \\
\hline Diferenciação escamosa & 0,564 & 0,599 & 0,062 & 0,434 \\
\hline Porcentagem de diferenciação escamosa & 0,851 & 0,834 & 0,207 & 0,89 \\
\hline Diferenciação glandular & 0,831 & 0,941 & 0,761 & 0,905 \\
\hline Porcentagem de diferenciação glandular & 0,994 & 0,997 & 0,973 & 0,697 \\
\hline Variante histológica & 0,415 & 0,676 & 0,225 & 0,254 \\
\hline Padrão da variante histológica & 0,966 & 0,881 & 0,967 & 0,299 \\
\hline Invasão linfovascular & 0,771 & 0,847 & 0,733 & - \\
\hline Invasão perineural & 0,529 & 0,663 & 0,441 & 0,919 \\
\hline Carcinoma in situ & 0,936 & 0,76 & 0,443 & 0,571 \\
\hline Estádio patológico tumoral (AJCC/TNM 2009) & 0,846 & 0,682 & 0,556 & 0,32 \\
\hline Estádio tumoral agrupado pT2 vs pT3+pT4 & 0,606 & 0,456 & 0,454 & 0,214 \\
\hline Estádio tumoral agrupado pT2+pT3 vs pT4 & 0,771 & 0,68 & 0,262 & 0,863 \\
\hline Metástase para linfonodo regional & 0,238 & 0,117 & 0,19 & - \\
\hline Tamanho da maior metástase & 0,676 & 0,465 & 0,472 & 0,851 \\
\hline Extensão neoplásica extranodal & 0,585 & 0,668 & 0,596 & 0,382 \\
\hline
\end{tabular}




\subsubsection{Súmula das associações entre as características anatomopatológicas e o escore para a imunoexpressão de MMP-9}

A tabela 8 apresenta a súmula das significâncias $(p)$ das diversas associações entre as características anatomopatológicas estudadas e a imunoexpressão de MMP-9 no tumor primário e na metástase linfonodal.

Tabela 8 - Sumário das significâncias das associações entre as variáveis anatomopatológicas e o escore para MMP-9 $(p<0,05)$

\begin{tabular}{l|ccc|c}
\hline \hline \multicolumn{4}{c}{ MMP-9 } \\
\cline { 2 - 5 } \multicolumn{1}{c}{ Variáveis anatomopatológicas } & \multicolumn{3}{c}{ Tumor primário } & Metástase \\
\cline { 2 - 5 } & Global & Epitélio & neoplásico & Estroma \\
& linfonodal \\
\hline Tamanho da neoplasia & 0,248 & 0,725 & 0,204 & 0,676 \\
Tamanho tumor agrupado (4,0 cm) & 0,068 & 0,65 & $\mathbf{0 , 0 8}$ & 0,116 \\
Focalidade & 0,17 & 0,253 & 0,654 & 0,606 \\
Grau histológico & - & - & - & - \\
Tipo/configuração da neoplasia & 0,965 & 0,988 & 0,699 & $\mathbf{0 , 0 7 2}$ \\
Porcentagem de padrão papilífero & 0,572 & 0,905 & 0,796 & 0,817 \\
Porcentagem de padrão papilifero agrupado (40\%) & 0,727 & 0,989 & 0,219 & 0,474 \\
Padrão arquitetural de invasão tumoral & 0,172 & $\mathbf{0 , 0 4 3}$ & $\mathbf{0 , 0 4 4}$ & 0,478 \\
Atipia nuclear & 0,164 & 0,15 & $\mathbf{0 , 0 3 1}$ & $\mathbf{0 , 0 8 3}$ \\
Componente sarcomatoide & 0,759 & 0,411 & $\mathbf{0 , 0 3 6}$ & 0,189 \\
Porcentagem de componente sarcomatoide & 0,526 & 0,761 & $\mathbf{0 , 0 1 3}$ & 0,189 \\
Diferenciação escamosa & $\mathbf{0 , 0 3 3}$ & 0,475 & 0,286 & 0,944 \\
Porcentagem de diferenciação escamosa & 0,26 & 0,847 & 0,324 & 0,898 \\
Diferenciação glandular & 0,779 & 0,869 & 0,831 & 0,776 \\
Porcentagem de diferenciação glandular & 0,951 & 0,967 & 0,901 & 0,781 \\
Variante histológica & 0,296 & 0,125 & 0,473 & 0,413 \\
Padrão da variante histológica & 0,625 & 0,32 & 0,984 & $\mathbf{0 , 0 2 1}$ \\
Invasão linfovascular & 0,303 & 0,309 & 0,722 & - \\
Invasão perineural & 0,576 & 0,183 & 0,115 & 0,619 \\
Carcinoma in situ & 0,456 & 0,329 & 0,287 & 0,676 \\
Estádio patológico tumoral (AJCC/TNM 2009) & 0,252 & 0,296 & $\mathbf{0 , 0 5}$ & 0,375 \\
Estádio tumoral agrupado pT2 vs pT3+pT4 & 0,604 & 0,763 & 0,131 & 0,859 \\
Estádio tumoral agrupado pT2+pT3 vs pT4 & $\mathbf{0 , 0 7 7}$ & $\mathbf{0 , 0 4 9}$ & 0,546 & 0,275 \\
Metástase para linfonodo regional & 0,552 & 0,565 & 0,219 & - \\
Tamanho da maior metástase & 0,848 & 0,897 & 0,468 & 0,859 \\
Extensão neoplásica extranodal & 0,282 & 0,193 & 0,243 & 0,405 \\
\hline \hline
\end{tabular}




\subsubsection{Súmula das associações entre as características anatomopatológicas e o escore para a imunoexpressão de MMP-14}

Para melhor comparação das diversas associações entre as características anatomopatológicas estudadas e a imunoexpressão de MMP14 no tumor primário e nas metástases linfonodais, a tabela 9 exibe uma súmula das significâncias (p) obtidas.

Tabela 9 - Sumário das significâncias das associações entre as variáveis anatomopatológicas e o escore para MMP-14 $(p<0,05)$

\begin{tabular}{l|ccc|c}
\hline \hline \multicolumn{4}{c}{ MMP-14 } \\
\cline { 2 - 5 } \multicolumn{1}{c}{ Variáveis anatomopatológicas } & \multicolumn{3}{c}{ Tumor primário } & Metástase \\
\cline { 2 - 5 } & Global & Epitélio \\
neoplásico & Estroma & linfonodal \\
\hline Tamanho da neoplasia & 0,425 & 0,68 & 0,624 & $\mathbf{0 , 0 7 2}$ \\
Tamanho tumor agrupado (4,0 cm) & 0,521 & 0,187 & 0,526 & 0,412 \\
Focalidade & 0,933 & 0,729 & 0,774 & 0,207 \\
Grau histológico & - & - & - & - \\
Tipo/configuração da neoplasia & 0,945 & 0,58 & 0,915 & 0,451 \\
Porcentagem de padrão papilifero & 0,584 & 0,27 & 0,313 & 0,633 \\
Porcentagem de padrão papilifero agrupado (40\%) & 0,373 & 0,163 & 0,711 & 0,694 \\
Padrão arquitetural de invasão tumoral & $\mathbf{0 , 0 2 2}$ & $\mathbf{0 , 0 4 5}$ & 0,15 & 0,192 \\
Atipia nuclear & 0,768 & 0,526 & 0,138 & 0,493 \\
Componente sarcomatoide & 0,906 & 0,942 & $\mathbf{0 , 0 7 1}$ & 0,213 \\
Porcentagem de componente sarcomatoide & 0,935 & 0,987 & $<0,001$ & $\mathbf{0 , 0 1 7}$ \\
Diferenciação escamosa & 0,73 & 0,723 & 0,939 & 0,306 \\
Porcentagem de diferenciação escamosa & 0,755 & 0,814 & 0,986 & 0,641 \\
Diferenciação glandular & 0,852 & 0,871 & 0,394 & 0,781 \\
Porcentagem de diferenciação glandular & 0,956 & 0,797 & 0,412 & 0,829 \\
Variante histológica & 0,6 & 0,159 & 0,925 & 0,342 \\
Padrão da variante histológica & 0,568 & 0,557 & 0,983 & 0,324 \\
Invasão linfovascular & 0,655 & 0,934 & 0,662 & - \\
Invasão perineural & 0,617 & 0,791 & 0,161 & 0,719 \\
Carcinoma in situ & 0,473 & 0,326 & 0,696 & 0,307 \\
Estádio patológico tumoral (AJCC/TNM 2009) & 0,844 & 0,856 & 0,109 & 0,71 \\
Estádio tumoral agrupado pT2 vs pT3+pT4 & 0,216 & 0,163 & 0,316 & 0,53 \\
Estádio tumoral agrupado pT2+pT3 vs pT4 & 0,88 & 0,961 & 0,672 & 0,53 \\
Metástase para linfonodo regional & 0,465 & 0,432 & 0,321 & - \\
Tamanho da maior metástase & 0,731 & 0,693 & 0,687 & 0,821 \\
Extensão neoplásica extranodal & 0,781 & 0,575 & 0,575 & 0,281 \\
\hline \hline
\end{tabular}




\subsubsection{Avaliação detalhada da expressão de MMP-2 no tumor primário e na metástase linfonodal}

As tabelas abaixo apresentam as associações significativas e com tendência às significâncias obtidas entre as variáveis clínico-patológicas e a reatividade de MMP-2 calculada pelo escore.

\subsubsection{Expressão global de MMP-2 no tumor primário}

Tabela 10 - Associação entre a imunoexpressão global de MMP-2 (escore) no tumor primário e o padrão arquitetural de invasão tumoral

\begin{tabular}{|c|c|c|c|c|c|c|c|}
\hline \multirow{2}{*}{$\begin{array}{c}\text { Padrão } \\
\text { arquitetural de } \\
\text { invasão tumoral }\end{array}$} & \multicolumn{6}{|c|}{ Escore - MMP-2 global } & \multirow{2}{*}{$\begin{array}{c}\text { TOTAL } \\
\text { n (\%) }\end{array}$} \\
\hline & 0 & 1 & 2 & 3 & 4 & 6 & \\
\hline nodular & 2 & 0 & 0 & 1 & 0 & 0 & $\begin{array}{c}3 \\
(4,9)\end{array}$ \\
\hline trabecular & 3 & 2 & 1 & 0 & 1 & 0 & $\begin{array}{c}7 \\
(11,5)\end{array}$ \\
\hline infiltrativo & 4 & 6 & 3 & 0 & 0 & 0 & $\begin{array}{c}13 \\
(21,3)\end{array}$ \\
\hline $\begin{array}{c}\text { misto, infiltrativo e } \\
\text { trabecular }\end{array}$ & 14 & 10 & 7 & 0 & 0 & 2 & $\begin{array}{c}33 \\
(54,1)\end{array}$ \\
\hline $\begin{array}{l}\text { misto, nodular e } \\
\text { trabecular }\end{array}$ & 2 & 0 & 1 & 2 & 0 & 0 & $\begin{array}{c}5 \\
(8,2)\end{array}$ \\
\hline $\begin{array}{l}\text { TOTAL } \\
\text { n (\%) }\end{array}$ & $\begin{array}{c}25 \\
(41,0)\end{array}$ & $\begin{array}{c}18 \\
(29,5)\end{array}$ & $\begin{array}{c}12 \\
(19,7)\end{array}$ & $\begin{array}{c}3 \\
(4,9)\end{array}$ & $\begin{array}{c}1 \\
(1,6)\end{array}$ & $\begin{array}{c}2 \\
(3,3)\end{array}$ & $\begin{array}{c}61 \\
(100)\end{array}$ \\
\hline
\end{tabular}

$x^{2}=34,694 \quad p=0,022$

A expressão global de MMP-2 no tumor primário foi significativamente maior nos casos onde o padrão arquitetural infiltrativo esteve presente, e associou-se inclusive com os maiores valores do escore. 


\subsubsection{Expressão de MMP-2 no epitélio neoplásico do tumor primário}

Tabela 11 - Associação entre a imunoexpressão de MMP-2 no epitélio neoplásico do tumor primário (escore) e o padrão arquitetural de invasão tumoral

\begin{tabular}{|c|c|c|c|c|c|c|c|}
\hline \multirow{2}{*}{$\begin{array}{c}\text { Padrão } \\
\text { arquitetural } \\
\text { de invasão } \\
\text { tumoral }\end{array}$} & \multicolumn{6}{|c|}{ Escore - MMP-2 epitélio neoplásico } & \multirow{2}{*}{$\begin{array}{c}\text { TOTAL } \\
\text { n (\%) }\end{array}$} \\
\hline & 0 & 1 & 2 & 3 & 4 & 6 & \\
\hline nodular & 2 & 0 & 0 & 1 & 0 & 0 & $\begin{array}{c}3 \\
(4,9)\end{array}$ \\
\hline trabecular & 4 & 2 & 0 & 0 & 1 & 0 & $\begin{array}{c}7 \\
(11,5)\end{array}$ \\
\hline infiltrativo & 4 & 7 & 2 & 0 & 0 & 0 & $\begin{array}{c}13 \\
(21,3)\end{array}$ \\
\hline $\begin{array}{c}\text { misto, } \\
\text { infiltrativo e } \\
\text { trabecular }\end{array}$ & 18 & 6 & 7 & 0 & 0 & 2 & $\begin{array}{c}33 \\
(54,1)\end{array}$ \\
\hline $\begin{array}{c}\text { misto, } \\
\text { nodular e } \\
\text { trabecular }\end{array}$ & 2 & 0 & 1 & 2 & 0 & 0 & $\begin{array}{c}5 \\
(8,2)\end{array}$ \\
\hline $\begin{array}{c}\text { TOTAL } \\
\text { n (\%) }\end{array}$ & $\begin{array}{c}30 \\
(49,2)\end{array}$ & $\begin{array}{c}15 \\
(24,6)\end{array}$ & $\begin{array}{c}10 \\
(16,4)\end{array}$ & $\begin{array}{c}3 \\
(4,9)\end{array}$ & $\begin{array}{c}1 \\
(1,6)\end{array}$ & $\begin{array}{c}2 \\
(3,3)\end{array}$ & $\begin{array}{c}61 \\
(100)\end{array}$ \\
\hline
\end{tabular}

$x^{2}=40,150 \quad p=0,005$

Assim como apresentado anteriormente, a expressão de MMP-2 no epitélio neoplásico do tumor primário também se mostrou significativamente maior nos casos com predomínio do padrão arquitetural infiltrativo, e associou-se inclusive com os maiores valores do escore. 


\subsubsection{Expressão de MMP-2 no estroma do tumor primário}

Tabela 12 - Associação entre a imunoexpressão de MMP-2 no estroma do tumor primário (escore) e a atipia nuclear

\begin{tabular}{c|cccc|c}
\hline \hline Grau de atipia nuclear & \multicolumn{3}{|c|}{ Escore - MMP-2 estroma } & TOTAL \\
& $\mathbf{0}$ & $\mathbf{1}$ & $\mathbf{2}$ & $\mathbf{3}$ & $\mathbf{n}(\%)$ \\
\hline moderada & 12 & 2 & 2 & 0 & $\begin{array}{c}16 \\
(26,2)\end{array}$ \\
intensa & 27 & 17 & 0 & 1 & $\begin{array}{c}45 \\
(73,8)\end{array}$ \\
\hline $\begin{array}{c}\text { TOTAL } \\
\mathbf{n}(\%)\end{array}$ & $\begin{array}{c}39 \\
(63,9)\end{array}$ & $\begin{array}{c}19 \\
(31,2)\end{array}$ & $\begin{array}{c}2 \\
(3,3)\end{array}$ & $\begin{array}{c}1 \\
(1,6)\end{array}$ & $\begin{array}{c}61 \\
(100)\end{array}$ \\
\hline \hline
\end{tabular}

$x^{2}=8,817 \quad p=0,032$

A expressão estromal de MMP-2 nos tumores primários mostrou-se significativamente associada à presença de atipia nuclear intensa, que na prática anatomopatológica se traduz por tumores morfologicamente pleomórficos.

Tabela 13 - Associação entre a imunoexpressão de MMP-2 no estroma do tumor primário (escore) e o componente sarcomatoide

\begin{tabular}{c|cccc|c}
\hline \hline Componente sarcomatoide & \multicolumn{4}{|c|}{ Escore - MMP-2 estroma } & $\begin{array}{c}\text { TOTAL } \\
\mathbf{n}(\%)\end{array}$ \\
\hline \multirow{2}{*}{$\begin{array}{c}\text { ausente } \\
\text { presente }\end{array}$} & $\mathbf{0}$ & $\mathbf{1}$ & $\mathbf{2}$ & $\mathbf{3}$ & $\begin{array}{c}52 \\
(85,2)\end{array}$ \\
\hline $\begin{array}{c}\text { TOTAL } \\
\text { n (\%) }\end{array}$ & 4 & 4 & 0 & 1 & $\begin{array}{c}9 \\
(14,8)\end{array}$ \\
\hline \hline
\end{tabular}

$x^{2}=7,351 \quad p=0,062$ 
Comparando a expressão de MMP-2 no estroma do tumor com a presença de componente sarcomatoide na neoplasia, observa-se uma tendência à significância nessa associação. Tal fato pode ser eventualmente explicado pelo limitado número de casos (9 casos) que apresentam o componente sarcomatoide como um dos constituintes do tumor primário.

Tabela 14 - Associação entre a imunoexpressão de MMP-2 no estroma do tumor primário (escore) e a porcentagem do componente sarcomatoide

\begin{tabular}{|c|c|c|c|c|c|}
\hline \multirow{2}{*}{$\begin{array}{l}\text { Porcentagem do } \\
\text { componente } \\
\text { sarcomatoide }\end{array}$} & \multicolumn{4}{|c|}{ Escore - MMP-2 estroma } & \multirow{2}{*}{$\begin{array}{c}\text { TOTAL } \\
\text { n (\%) }\end{array}$} \\
\hline & 0 & 1 & 2 & 3 & \\
\hline ausente & 35 & 15 & 2 & 0 & $52(85,3)$ \\
\hline $1-5 \%$ (focal) & 0 & 1 & 0 & 0 & $1 \quad(1,6)$ \\
\hline $6-10 \%$ & 1 & 0 & 0 & 1 & $2 \quad(3,3)$ \\
\hline $11-20 \%$ & 1 & 0 & 0 & 0 & $1 \quad(1,6)$ \\
\hline $21-30 \%$ & 1 & 0 & 0 & 0 & $1 \quad(1,6)$ \\
\hline $81-90 \%$ & 0 & 2 & 0 & 0 & $2 \quad(3,3)$ \\
\hline $91-100 \%$ & 1 & 1 & 0 & 0 & $2 \quad(3,3)$ \\
\hline $\begin{array}{c}\text { TOTAL } \\
\text { n (\%) }\end{array}$ & $\begin{array}{c}39 \\
(63,9)\end{array}$ & $\begin{array}{c}19 \\
(31,2)\end{array}$ & $\begin{array}{c}2 \\
(3,3)\end{array}$ & $\begin{array}{c}1 \\
(1,6)\end{array}$ & $61(100)$ \\
\hline
\end{tabular}

$x^{2}=38,514 p=0,003$

A subestratificação do componente sarcomatoide de acordo com a sua extensão no tumor primário permitiu realçar sua associação significante com a expressão estromal de MMP-2, inclusive nos casos que demonstram grande quantidade desse componente (>80\%). 
Tabela 15 - Associação entre a imunoexpressão de MMP-2 no estroma do tumor primário (escore) e a diferenciação escamosa

\begin{tabular}{|c|c|c|c|c|c|}
\hline \multirow{2}{*}{ Diferenciação escamosa } & \multicolumn{4}{|c|}{ Escore - MMP-2 estroma } & \multirow{2}{*}{$\begin{array}{c}\text { TOTAL } \\
\text { n (\%) }\end{array}$} \\
\hline & 0 & 1 & 2 & 3 & \\
\hline ausente & 35 & 16 & 2 & 0 & $\begin{array}{c}53 \\
(86,9)\end{array}$ \\
\hline presente & 4 & 3 & 0 & 1 & $\begin{array}{c}8 \\
(13,1)\end{array}$ \\
\hline $\begin{array}{c}\text { TOTAL } \\
\text { n (\%) }\end{array}$ & $\begin{array}{c}39 \\
(63,9)\end{array}$ & $\begin{array}{c}19 \\
(31,2)\end{array}$ & $\begin{array}{c}2 \\
(3,3)\end{array}$ & $\begin{array}{c}1 \\
(1,6)\end{array}$ & $\begin{array}{c}61 \\
(100)\end{array}$ \\
\hline
\end{tabular}

$x^{2}=7,326 \quad p=0,062$

A expressão de MMP-2 no estroma mostrou tendência à associação com a presença de componente de diferenciação escamosa. Ressalte-se que essa associação pode ter interferência do fato do maior escore observado no estroma ser detectado em um caso onde a diferenciação escamosa faz-se presente, além do limitado número de casos (8 casos) que apresentam o componente escamoso.

\subsubsection{Expressão de MMP-2 na metástase linfonodal}

Tabela 16 - Associação entre a imunoexpressão de MMP-2 na metástase linfonodal (escore) e o tipo/configuração do tumor primário

\begin{tabular}{|c|c|c|c|c|c|c|c|c|c|}
\hline \multirow{2}{*}{ Tipo histológico } & \multicolumn{8}{|c|}{ Escore MMP-2 metástase linfonodal } & \multirow{2}{*}{$\begin{array}{c}\text { TOTAL } \\
\text { n (\%) }\end{array}$} \\
\hline & 0 & 1 & 2 & 3 & 4 & 5 & 6 & 8 & \\
\hline não papilífero & 10 & 2 & 2 & 1 & 1 & 1 & 1 & 2 & $\begin{array}{c}20 \\
(62,5)\end{array}$ \\
\hline $\begin{array}{c}\text { misto, papilífero e } \\
\text { não papilífero }\end{array}$ & 2 & 8 & 1 & 0 & 1 & 0 & 0 & 0 & $\begin{array}{c}12 \\
(37,5)\end{array}$ \\
\hline $\begin{array}{c}\text { TOTAL } \\
\text { n (\%) }\end{array}$ & $\begin{array}{c}12 \\
(37,5)\end{array}$ & $\begin{array}{c}10 \\
(31,3)\end{array}$ & $\begin{array}{c}3 \\
(9,4)\end{array}$ & $\begin{array}{c}1 \\
(3,1)\end{array}$ & $\begin{array}{c}2 \\
(6,3)\end{array}$ & $\begin{array}{c}1 \\
(3,1)\end{array}$ & $\begin{array}{c}1 \\
(3,1)\end{array}$ & $\begin{array}{c}2 \\
(6,3)\end{array}$ & $\begin{array}{c}32 \\
(100)\end{array}$ \\
\hline
\end{tabular}

$x^{2}=13,084 p=0,07$ 
A expressão de MMP-2 na metástase linfonodal mostrou tendência à significância quando houve o predomínio da forma não papilífera.

\subsubsection{Avaliação detalhada da expressão de MMP-9 no tumor primário e na metástase linfonodal}

As tabelas abaixo apresentam as associações significativas e com tendência à significância obtidas entre as variáveis clínico-patológicas e a reatividade de MMP-9 calculada pelo escore.

\subsubsection{Expressão global de MMP-9 no tumor primário}

Tabela 17 - Associação entre a imunoexpressão global de MMP-9 no tumor primário (escore) e a diferenciação escamosa

\begin{tabular}{|c|c|c|c|c|c|c|c|c|c|c|c|c|c|c|c|}
\hline \multirow{2}{*}{$\begin{array}{c}\text { Diferenciação } \\
\text { escamosa }\end{array}$} & \multicolumn{14}{|c|}{ MMP-9 - Escore H global } & \multirow{2}{*}{$\begin{array}{c}\text { TOTAL } \\
\text { n (\%) }\end{array}$} \\
\hline & 0 & 1 & 2 & 3 & 4 & 5 & 6 & 7 & 8 & 10 & 12 & 14 & 16 & 18 & \\
\hline Ausente & 3 & 13 & 3 & 4 & 3 & 2 & 2 & 2 & 4 & 4 & 4 & 2 & 5 & 1 & $\begin{array}{c}52 \\
(86,7)\end{array}$ \\
\hline Presente & 0 & 1 & 0 & 0 & 1 & 1 & 4 & 0 & 0 & 0 & 0 & 0 & 0 & 1 & $\begin{array}{c}8 \\
(13,3)\end{array}$ \\
\hline $\begin{array}{c}\text { TOTAL } \\
\text { n (\%) }\end{array}$ & $\begin{array}{c}3 \\
(5)\end{array}$ & $\begin{array}{c}14 \\
(23,3)\end{array}$ & $\begin{array}{c}3 \\
(5)\end{array}$ & $\begin{array}{c}4 \\
(6,7)\end{array}$ & $\begin{array}{c}4 \\
(6,7)\end{array}$ & $\begin{array}{c}3 \\
(5)\end{array}$ & $\begin{array}{c}6 \\
(10)\end{array}$ & $\begin{array}{c}2 \\
(3,3)\end{array}$ & $\begin{array}{c}4 \\
(6,7)\end{array}$ & $\begin{array}{c}4 \\
(6,7)\end{array}$ & $\begin{array}{c}4 \\
(6,7)\end{array}$ & $\begin{array}{c}2 \\
(3,3)\end{array}$ & $\begin{array}{c}5 \\
(8,3)\end{array}$ & $\begin{array}{c}2 \\
(3,3)\end{array}$ & $\begin{array}{c}60 \\
(100)\end{array}$ \\
\hline
\end{tabular}

$x^{2}=23,839 \quad p=0,033$

A associação entre a expressão global de MMP-9 no tumor primário e a diferenciação escamosa mostrou-se significante, com destaque para o fato de todos os casos que exibiram a diferenciação escamosa também terem expressado MMP-9, inclusive com o maior valor do escore obtido. 
Tabela 18 - Associação entre a imunoexpressão global de MMP-9 no tumor primário (escore) e o estádio tumoral agrupado $\mathrm{pT} 2+\mathrm{pT} 3$ versus $\mathrm{pT} 4$

\begin{tabular}{|c|c|c|c|c|c|c|c|c|c|c|c|c|c|c|c|}
\hline \multirow{2}{*}{$\begin{array}{c}\text { Estádio } \\
\text { tumoral } \\
\text { agrupado }\end{array}$} & \multicolumn{14}{|c|}{ Escore - MMP-9 global } & \multirow{2}{*}{$\begin{array}{c}\text { TOTAL } \\
\text { n (\%) }\end{array}$} \\
\hline & 0 & 1 & 2 & 3 & 4 & 5 & 6 & 7 & 8 & 10 & 12 & 14 & 16 & 18 & \\
\hline pT2 + pT3 & 3 & 12 & 3 & 1 & 4 & 3 & 3 & 2 & 3 & 3 & 3 & 0 & 4 & 2 & $\begin{array}{c}46 \\
(76,7)\end{array}$ \\
\hline pT4 & 0 & 2 & 0 & 3 & 0 & 0 & 3 & 0 & 1 & 1 & 1 & 2 & 1 & 0 & $\begin{array}{c}14 \\
(23,3)\end{array}$ \\
\hline $\begin{array}{c}\text { TOTAL } \\
\text { n (\%) }\end{array}$ & $\begin{array}{c}3 \\
(5)\end{array}$ & $\begin{array}{c}14 \\
(23,3)\end{array}$ & $\begin{array}{c}3 \\
(5)\end{array}$ & $\begin{array}{c}4 \\
(6,7)\end{array}$ & $\begin{array}{c}4 \\
(6,7)\end{array}$ & $\begin{array}{c}3 \\
(5)\end{array}$ & $\begin{array}{c}6 \\
(10)\end{array}$ & $\begin{array}{c}2 \\
(3,3)\end{array}$ & $\begin{array}{c}4 \\
(6,7)\end{array}$ & $\begin{array}{c}4 \\
(6,7)\end{array}$ & $\begin{array}{c}4 \\
(6,7)\end{array}$ & $\begin{array}{c}2 \\
(3,3)\end{array}$ & $\begin{array}{c}5 \\
(8,3)\end{array}$ & $\begin{array}{c}2 \\
(3,3)\end{array}$ & $\begin{array}{c}60 \\
(100)\end{array}$ \\
\hline
\end{tabular}

$x^{2}=20,790 \quad p=0,077$

A expressão global de MMP-9 no tumor primário mostrou tendência à associação com o estádio patológico quando agrupamos os casos infiltrativos até camada muscular própria com aqueles que atingiram o tecido perivesical (pT2 + pT3) versus os com invasão nos órgãos adjacentes (pT4).

\subsubsection{Expressão de MMP-9 no epitélio neoplásico do tumor primário}

Tabela 19 - Associação entre a imunoexpressão de MMP-9 no epitélio neoplásico do tumor primário (escore) e o estádio tumoral agrupado pT2+pT3 versus pT4

\begin{tabular}{|c|c|c|c|c|c|c|c|c|c|c|c|c|c|c|}
\hline \multirow{2}{*}{$\begin{array}{c}\text { Estádio } \\
\text { tumoral } \\
\text { agrupado }\end{array}$} & \multicolumn{13}{|c|}{ Escore - MMP-9 epitélio neoplásico } & \multirow{2}{*}{$\begin{array}{c}\text { TOTAL } \\
\text { n (\%) }\end{array}$} \\
\hline & 0 & 1 & 2 & 3 & 4 & 5 & 6 & 7 & 8 & 12 & 14 & 16 & 18 & \\
\hline pT2 + pT3 & 9 & 7 & 3 & 2 & 4 & 5 & 2 & 2 & 3 & 3 & 0 & 4 & 2 & $\begin{array}{c}46 \\
(76,7)\end{array}$ \\
\hline pT4 & 0 & 2 & 0 & 6 & 1 & 1 & 1 & 1 & 0 & 0 & 1 & 1 & 0 & $\begin{array}{c}14 \\
(23,3)\end{array}$ \\
\hline $\begin{array}{c}\text { TOTAL } \\
\text { n (\%) }\end{array}$ & $\begin{array}{c}9 \\
(15)\end{array}$ & $\begin{array}{c}9 \\
(15)\end{array}$ & $\begin{array}{c}3 \\
(5)\end{array}$ & $\begin{array}{c}8 \\
(13,3 \\
)\end{array}$ & $\begin{array}{c}5 \\
(8,3)\end{array}$ & $\begin{array}{c}6 \\
(10)\end{array}$ & $\begin{array}{c}3 \\
(5)\end{array}$ & $\begin{array}{c}3 \\
(5)\end{array}$ & $\begin{array}{c}3 \\
(5)\end{array}$ & $\begin{array}{c}3 \\
(5)\end{array}$ & $\begin{array}{c}1 \\
(1,7)\end{array}$ & $\begin{array}{c}5 \\
(8,3)\end{array}$ & $\begin{array}{c}2 \\
(3,3)\end{array}$ & $\begin{array}{c}60 \\
(100)\end{array}$ \\
\hline
\end{tabular}


A expressão de MMP-9 compartimentalizada ao epitélio neoplásico mostrou-se significativamente associada com o estádio patológico agrupando os casos pT2 + pT3 versus pT4, mostrando que a tendência verificada em sua expressão global deve ser principalmente decorrente da expressão no epitélio neoplásico.

Tabela 20 - Associação entre a imunoexpressão de MMP-9 no epitélio neoplásico do tumor primário (escore) e o padrão arquitetural de invasão tumoral

\begin{tabular}{|c|c|c|c|c|c|c|c|c|c|c|c|c|c|c|}
\hline \multirow{2}{*}{$\begin{array}{c}\text { Padrão } \\
\text { arquitetural } \\
\text { de invasão }\end{array}$} & \multicolumn{13}{|c|}{ Escore - MMP-9 epitélio neoplásico } & \multirow{2}{*}{$\begin{array}{c}\text { TOTAL } \\
\text { n (\%) }\end{array}$} \\
\hline & 0 & 1 & 2 & 3 & 4 & 5 & 6 & 7 & 8 & 12 & 14 & 16 & 18 & \\
\hline nodular & 0 & 0 & 1 & 1 & 0 & 0 & 0 & 0 & 0 & 0 & 0 & 0 & 0 & $\begin{array}{c}2 \\
(3,3)\end{array}$ \\
\hline trabecular & 2 & 2 & 0 & 0 & 0 & 0 & 1 & 0 & 1 & 1 & 0 & 0 & 0 & $\begin{array}{c}7 \\
(11,7)\end{array}$ \\
\hline infiltrativo & 1 & 2 & 0 & 3 & 0 & 0 & 0 & 0 & 2 & 0 & 0 & 3 & 2 & $\begin{array}{c}13 \\
(21,7)\end{array}$ \\
\hline $\begin{array}{c}\text { misto, } \\
\text { infiltrativo e } \\
\text { trabecular }\end{array}$ & 5 & 5 & 2 & 3 & 5 & 5 & 1 & 2 & 0 & 2 & 1 & 2 & 0 & $\begin{array}{c}33 \\
(55)\end{array}$ \\
\hline $\begin{array}{c}\text { misto, } \\
\text { nodular e } \\
\text { trabecular }\end{array}$ & 1 & 0 & 0 & 1 & 0 & 1 & 1 & 1 & 0 & 0 & 0 & 0 & 0 & $\begin{array}{c}5 \\
(8,3)\end{array}$ \\
\hline $\begin{array}{c}\text { TOTAL } \\
\text { n (\%) }\end{array}$ & $\begin{array}{c}9 \\
(15)\end{array}$ & $\begin{array}{c}9 \\
(15)\end{array}$ & $\begin{array}{c}3 \\
(5)\end{array}$ & $\begin{array}{c}8 \\
(13,3)\end{array}$ & $\begin{array}{c}5 \\
(8,3)\end{array}$ & $\begin{array}{c}6 \\
(10)\end{array}$ & $\begin{array}{c}3 \\
(5)\end{array}$ & $\begin{array}{c}3 \\
(5)\end{array}$ & $\begin{array}{c}3 \\
(5)\end{array}$ & $\begin{array}{c}3 \\
(5)\end{array}$ & $\begin{array}{c}1 \\
(1,7)\end{array}$ & $\begin{array}{c}5 \\
(8,3)\end{array}$ & $\begin{array}{c}2 \\
(3,3)\end{array}$ & $\begin{array}{c}60 \\
(100)\end{array}$ \\
\hline
\end{tabular}

$x^{2}=70,764 \quad p=0,043$

A expressão de MMP-9 no epitélio neoplásico do tumor primário mostrou associação significativa com o padrão arquitetural de invasão tumoral, principalmente pelo predomínio do padrão infiltrativo que exibe os maiores valores do escore, à semelhança do anteriormente relatado quanto à expressão de MMP-2. 


\subsubsection{Expressão de MMP-9 no estroma do tumor primário}

Tabela 21 - Associação entre a imunoexpressão de MMP-9 no estroma do tumor primário (escore) e o padrão arquitetural de invasão tumoral

\begin{tabular}{|c|c|c|c|c|c|c|c|c|c|c|c|}
\hline \multirow{2}{*}{$\begin{array}{c}\text { Padrão } \\
\text { arquitetural de } \\
\text { invasão tumoral }\end{array}$} & \multicolumn{10}{|c|}{ Escore - MMP-9 estroma } & \multirow{2}{*}{$\begin{array}{c}\text { TOTAL } \\
\text { n (\%) }\end{array}$} \\
\hline & 0 & 1 & 2 & 3 & 4 & 5 & 6 & 8 & 10 & 12 & \\
\hline nodular & 1 & 1 & 0 & 0 & 0 & 0 & 0 & 0 & 0 & 0 & $\begin{array}{c}2 \\
(3,3)\end{array}$ \\
\hline trabecular & 2 & 1 & 1 & 0 & 1 & 0 & 0 & 1 & 0 & 1 & $\begin{array}{c}7 \\
(11,7)\end{array}$ \\
\hline infiltrativo & 0 & 5 & 1 & 1 & 2 & 0 & 1 & 3 & 0 & 0 & $\begin{array}{c}13 \\
(21,7)\end{array}$ \\
\hline $\begin{array}{c}\text { misto, infiltrativo } \\
\text { e trabecular }\end{array}$ & 3 & 11 & 4 & 1 & 3 & 0 & 4 & 4 & 3 & 0 & $\begin{array}{l}33 \\
(55)\end{array}$ \\
\hline $\begin{array}{l}\text { misto, nodular e } \\
\text { trabecular }\end{array}$ & 2 & 1 & 1 & 0 & 0 & 1 & 0 & 0 & 0 & 0 & $\begin{array}{c}5 \\
(8,3)\end{array}$ \\
\hline $\begin{array}{c}\text { TOTAL } \\
\text { n (\%) }\end{array}$ & $\begin{array}{c}8 \\
(13,3)\end{array}$ & $\begin{array}{c}19 \\
(31,7)\end{array}$ & $\begin{array}{c}7 \\
(11,7)\end{array}$ & $\begin{array}{c}2 \\
(3,3)\end{array}$ & $\begin{array}{c}6 \\
(10)\end{array}$ & $\begin{array}{c}1 \\
(1,7)\end{array}$ & $\begin{array}{c}5 \\
(8,3)\end{array}$ & $\begin{array}{c}8 \\
(13,3)\end{array}$ & $\begin{array}{c}3 \\
(5)\end{array}$ & $\begin{array}{c}1 \\
(1,7)\end{array}$ & $\begin{array}{c}60 \\
(100)\end{array}$ \\
\hline
\end{tabular}

$x^{2}=56,414 \quad p=0,044$

A expressão de MMP-9 no estroma tumoral mostrou-se significantemente associada com o padrão arquitetural de invasão, com índices mais altos encontrados nos tumores com padrão infiltrativo e trabecular.

Tabela 22 - Associação entre a imunoexpressão de MMP-9 no estroma do tumor primário (escore) e a atipia nuclear

\begin{tabular}{c|cccccccccc|c}
\hline \hline Atipia & \multicolumn{10}{c|}{ Escore - MMP-9 estroma } & TOTAL \\
nuclear & $\mathbf{0}$ & $\mathbf{1}$ & $\mathbf{2}$ & $\mathbf{3}$ & $\mathbf{4}$ & $\mathbf{5}$ & $\mathbf{6}$ & $\mathbf{8}$ & $\mathbf{1 0}$ & $\mathbf{1 2}$ & $\mathbf{n}(\%)$ \\
\hline moderada & 5 & 4 & 2 & 0 & 4 & 0 & 0 & 0 & 0 & 0 & $\begin{array}{c}15 \\
(25)\end{array}$ \\
intensa & 3 & 15 & 5 & 2 & 2 & 1 & 5 & 8 & 3 & 1 & $\begin{array}{c}45 \\
(75)\end{array}$ \\
\hline $\begin{array}{c}\text { TOTAL } \\
\mathbf{n}(\%)\end{array}$ & 8 & 19 & 7 & 2 & 6 & 1 & 5 & 8 & 3 & 1 & 60 \\
$(13,3)$ & $(31,7)$ & $(11,7)$ & $(3,3)$ & $(10)$ & $(1,7)$ & $(8,3)$ & $(13,3)$ & $(5)$ & $(1,7)$ & $(100)$ \\
\hline \hline
\end{tabular}

$x^{2}=18,428 \quad p=0,031$ 
A expressão estromal de MMP-9 mostrou associação significante com a presença de atipia nuclear intensa, valorizando a análise morfológica do núcleo de células neoplásicas mesmo nesta casuística em que todos os carcinomas mostraram alto grau histológico.

Tabela 23 - Associação entre a imunoexpressão de MMP-9 no estroma do tumor primário (escore) e o componente sarcomatoide

\begin{tabular}{|c|c|c|c|c|c|c|c|c|c|c|c|}
\hline \multirow{2}{*}{$\begin{array}{c}\text { Componente } \\
\text { sarcomatoide }\end{array}$} & \multicolumn{10}{|c|}{ Escore - MMP-9 estroma } & \multirow{2}{*}{$\begin{array}{c}\text { TOTAL } \\
\text { n (\%) }\end{array}$} \\
\hline & 0 & 1 & 2 & 3 & 4 & 5 & 6 & 8 & 10 & 12 & \\
\hline ausente & 8 & 17 & 7 & 0 & 5 & 1 & 3 & 7 & 2 & 1 & $\begin{array}{l}51 \\
(85)\end{array}$ \\
\hline presente & 0 & 2 & 0 & 2 & 1 & 0 & 2 & 1 & 1 & 0 & $\begin{array}{c}9 \\
(15)\end{array}$ \\
\hline $\begin{array}{c}\text { TOTAL } \\
\text { n (\%) }\end{array}$ & $\begin{array}{c}8 \\
(13,3)\end{array}$ & $\begin{array}{c}19 \\
(31,7)\end{array}$ & $\begin{array}{c}7 \\
(11,7)\end{array}$ & $\begin{array}{c}2 \\
(3,3)\end{array}$ & $\begin{array}{c}6 \\
(10)\end{array}$ & $\begin{array}{c}1 \\
(1,7)\end{array}$ & $\begin{array}{c}5 \\
(8,3)\end{array}$ & $\begin{array}{c}8 \\
(13,3)\end{array}$ & $\begin{array}{c}3 \\
(5)\end{array}$ & $\begin{array}{c}1 \\
(1,7)\end{array}$ & $\begin{array}{c}60 \\
(100)\end{array}$ \\
\hline
\end{tabular}

$x^{2}=17,926 \quad p=0,036$

A associação entre a expressão de MMP-9 no estroma e o componente sarcomatoide na neoplasia primária mostrou-se significante, a se salientar que todos os 9 casos que demonstraram componente sarcomatoide também expressaram a enzima no estroma. 
Tabela 24 - Associação entre a imunoexpressão de MMP-9 no estroma do tumor primário (escore) e a porcentagem do componente sarcomatoide

\begin{tabular}{|c|c|c|c|c|c|c|c|c|c|c|c|}
\hline \multirow{2}{*}{$\begin{array}{c}\text { Porcentagem do } \\
\text { componente } \\
\text { sarcomatoide }\end{array}$} & \multicolumn{10}{|c|}{ Escore - MMP-9 estroma } & \multirow{2}{*}{$\begin{array}{c}\text { TOTAL } \\
\text { n (\%) }\end{array}$} \\
\hline & 0 & 1 & 2 & 3 & 4 & 5 & 6 & 8 & 10 & 12 & \\
\hline ausente & 8 & 17 & 7 & 0 & 5 & 1 & 3 & 7 & 2 & 1 & $\begin{array}{c}51 \\
(85)\end{array}$ \\
\hline $1-5 \%$ & 0 & 0 & 0 & 0 & 0 & 0 & 1 & 0 & 0 & 0 & $\begin{array}{c}1 \\
(1,7)\end{array}$ \\
\hline $6-10 \%$ & 0 & 1 & 0 & 0 & 1 & 0 & 0 & 0 & 0 & 0 & $\begin{array}{c}2 \\
(3,3)\end{array}$ \\
\hline $11-20 \%$ & 0 & 0 & 0 & 0 & 0 & 0 & 1 & 0 & 0 & 0 & $\begin{array}{c}1 \\
(1,7)\end{array}$ \\
\hline $21-30 \%$ & 0 & 0 & 0 & 0 & 0 & 0 & 0 & 0 & 1 & 0 & $\begin{array}{c}1 \\
(1,7)\end{array}$ \\
\hline $81-90 \%$ & 0 & 0 & 0 & 1 & 0 & 0 & 0 & 1 & 0 & 0 & $\begin{array}{c}2 \\
(3,3)\end{array}$ \\
\hline $91-100 \%$ & 0 & 1 & 0 & 1 & 0 & 0 & 0 & 0 & 0 & 0 & $\begin{array}{c}2 \\
(3,3)\end{array}$ \\
\hline $\begin{array}{c}\text { TOTAL } \\
\text { n (\%) }\end{array}$ & $\begin{array}{c}8 \\
(13,3)\end{array}$ & $\begin{array}{c}19 \\
(31,7)\end{array}$ & $\begin{array}{c}7 \\
(11,7)\end{array}$ & $\begin{array}{c}2 \\
(3,3)\end{array}$ & $\begin{array}{c}6 \\
(10)\end{array}$ & $\begin{array}{c}1 \\
(1,7)\end{array}$ & $\begin{array}{c}5 \\
(8,3)\end{array}$ & $\begin{array}{c}8 \\
(13,3)\end{array}$ & $\begin{array}{c}3 \\
(5)\end{array}$ & $\begin{array}{c}1 \\
(1,7)\end{array}$ & $\begin{array}{c}60 \\
(100)\end{array}$ \\
\hline
\end{tabular}

A expressão estromal de MMP-9 mostrou associação significante com o estudo semiquantificado do componente sarcomatoide, de acordo com a sua extensão no tumor primário.

Tabela 25 - Associação entre a imunoexpressão de MMP-9 no estroma do tumor primário (escore) e o estádio tumoral (AJCC/TNM 2009)

\begin{tabular}{|c|c|c|c|c|c|c|c|c|c|c|c|}
\hline \multirow{2}{*}{$\begin{array}{c}\text { Estádio } \\
\text { tumoral } \\
\text { TNM } 2009 \\
\end{array}$} & \multicolumn{10}{|c|}{ Escore - MMP-9 estroma } & \multirow{2}{*}{$\begin{array}{c}\text { TOTAL } \\
\text { n (\%) }\end{array}$} \\
\hline & 0 & 1 & 2 & 3 & 4 & 5 & 6 & 8 & 10 & 12 & \\
\hline pT2a & 0 & 0 & 0 & 0 & 0 & 0 & 1 & 0 & 0 & 0 & $\begin{array}{c}1 \\
(1,7)\end{array}$ \\
\hline pT2b & 3 & 2 & 1 & 0 & 0 & 1 & 1 & 1 & 1 & 0 & $\begin{array}{c}10 \\
(16,7)\end{array}$ \\
\hline pT3a & 1 & 11 & 0 & 2 & 1 & 0 & 0 & 3 & 0 & 1 & $\begin{array}{c}19 \\
(31,7)\end{array}$ \\
\hline pT3b & 1 & 4 & 5 & 0 & 3 & 0 & 0 & 2 & 1 & 0 & $\begin{array}{c}16 \\
(26,7)\end{array}$ \\
\hline pT4a & 3 & 2 & 1 & 0 & 2 & 0 & 3 & 2 & 1 & 0 & $\begin{array}{c}14 \\
(23,3)\end{array}$ \\
\hline $\begin{array}{c}\text { TOTAL } \\
\text { n (\%) }\end{array}$ & $\begin{array}{c}8 \\
(13,3)\end{array}$ & $\begin{array}{c}19 \\
(31,7)\end{array}$ & $\begin{array}{c}7 \\
(11,7)\end{array}$ & $\begin{array}{c}2 \\
(3,3)\end{array}$ & $\begin{array}{c}6 \\
(10)\end{array}$ & $\begin{array}{c}1 \\
(1,7)\end{array}$ & $\begin{array}{c}5 \\
(8,3)\end{array}$ & $\begin{array}{c}8 \\
(13,3)\end{array}$ & $\begin{array}{c}3 \\
(5)\end{array}$ & $\begin{array}{c}1 \\
(1,7)\end{array}$ & $\begin{array}{c}60 \\
(100)\end{array}$ \\
\hline
\end{tabular}

$x^{2}=55,785 \quad p=0,05$ 
A expressão de MMP-9 no estroma demonstrou associação com o estádio patológico tumoral com $p=0,05$, explicada pelo achado de que grande parte dos maiores escores foi detectada nos tumores localmente avançados.

\subsubsection{Expressão de MMP-9 na metástase linfonodal}

Tabela 26 - Associação entre a imunoexpressão de MMP-9 na metástase linfonodal (escore) e o tipo/configuração do tumor primário

\begin{tabular}{|c|c|c|c|c|c|c|c|c|c|c|c|c|c|c|}
\hline \multirow{2}{*}{$\begin{array}{c}\text { Tipo/ } \\
\text { configuração } \\
\text { tumor }\end{array}$} & \multicolumn{13}{|c|}{ Escore - MMP-9 metástase linfonodal } & \multirow{2}{*}{$\begin{array}{c}\text { TOTAL } \\
\text { n (\%) }\end{array}$} \\
\hline & 0 & 1 & 2 & 3 & 4 & 5 & 6 & 8 & 9 & 10 & 14 & 16 & 18 & \\
\hline $\begin{array}{c}\text { não } \\
\text { papilífero }\end{array}$ & 1 & 3 & 3 & 1 & 1 & 0 & 1 & 0 & 1 & 1 & 2 & 3 & 2 & $\begin{array}{c}19 \\
(61,3)\end{array}$ \\
\hline misto & 3 & 1 & 0 & 1 & 2 & 2 & 0 & 3 & 0 & 0 & 0 & 0 & 0 & $\begin{array}{c}12 \\
(38,7)\end{array}$ \\
\hline $\begin{array}{c}\text { TOTAL } \\
\text { n (\%) }\end{array}$ & $\begin{array}{c}4 \\
(12,9)\end{array}$ & $\begin{array}{c}4 \\
(12,9)\end{array}$ & $\begin{array}{c}3 \\
(9,7)\end{array}$ & $\begin{array}{c}2 \\
(6,5)\end{array}$ & $\begin{array}{c}3 \\
(9,7)\end{array}$ & $\begin{array}{c}2 \\
(6,5)\end{array}$ & $\begin{array}{c}1 \\
(3,2)\end{array}$ & $\begin{array}{c}3 \\
(9,7)\end{array}$ & $\begin{array}{c}1 \\
(3,2)\end{array}$ & $\begin{array}{c}1 \\
(3,2)\end{array}$ & $\begin{array}{c}2 \\
(6,5)\end{array}$ & $\begin{array}{c}3 \\
(9,7)\end{array}$ & $\begin{array}{c}2 \\
(6,5)\end{array}$ & $\begin{array}{c}31 \\
(100)\end{array}$ \\
\hline
\end{tabular}

A expressão de MMP-9 nas metástases linfonodais mostrou tendência à associação com o tipo/configuração do tumor primário, principalmente pelo achado de que a maioria dos tumores não papilíferos expressaram MMP-9 na metástase, inclusive com os maiores valores do escore $(\geq 10)$.

Tabela 27 - Associação entre a imunoexpressão de MMP-9 na metástase linfonodal (escore) e atipia nuclear do tumor primário

\begin{tabular}{|c|c|c|c|c|c|c|c|c|c|c|c|c|c|c|}
\hline \multirow{2}{*}{$\begin{array}{c}\text { Atipia } \\
\text { nuclear }\end{array}$} & \multicolumn{13}{|c|}{ Escore - MMP-9 metástase linfonodal } & \multirow{2}{*}{$\begin{array}{c}\text { TOTAL } \\
\text { n (\%) }\end{array}$} \\
\hline & 0 & 1 & 2 & 3 & 4 & 5 & 6 & 8 & 9 & 10 & 14 & 16 & 18 & \\
\hline moderada & 0 & 0 & 1 & 0 & 0 & 2 & 0 & 1 & 1 & 0 & 1 & 0 & 0 & $\begin{array}{c}6 \\
(19,4)\end{array}$ \\
\hline intensa & 4 & 4 & 2 & 2 & 3 & 0 & 1 & 2 & 0 & 1 & 1 & 3 & 2 & $\begin{array}{c}25 \\
(80,6)\end{array}$ \\
\hline $\begin{array}{c}\text { TOTAL } \\
\text { n (\%) }\end{array}$ & $\begin{array}{c}4 \\
(12,9)\end{array}$ & $\begin{array}{c}4 \\
(12,9)\end{array}$ & $\begin{array}{c}3 \\
(9,7)\end{array}$ & $\begin{array}{c}2 \\
(6,5)\end{array}$ & $\begin{array}{c}3 \\
(9,7)\end{array}$ & $\begin{array}{c}2 \\
(6,5)\end{array}$ & $\begin{array}{c}1 \\
(3,2)\end{array}$ & $\begin{array}{c}3 \\
(9,7)\end{array}$ & $\begin{array}{c}1 \\
(3,2)\end{array}$ & $\begin{array}{c}1 \\
(3,2)\end{array}$ & $\begin{array}{c}2 \\
(6,5)\end{array}$ & $\begin{array}{c}3 \\
(9,7)\end{array}$ & $\begin{array}{c}2 \\
(6,5)\end{array}$ & $\begin{array}{c}31 \\
(100)\end{array}$ \\
\hline
\end{tabular}

$x^{2}=19,254 \quad p=0,083$ 
A expressão de MMP-9 na metástase linfonodal mostrou tendência à associação com a presença de atipia nuclear intensa no tumor primário, à semelhança com sua positividade no estroma do tumor primário, já relatada.

Tabela 28 - Associação entre a imunoexpressão de MMP-9 na metástase linfonodal (escore) e o tipo da variante histológica do tumor primário

\begin{tabular}{c|cccccccccccccc}
\hline \hline $\begin{array}{c}\text { Tipo de } \\
\text { variante } \\
\text { histológica }\end{array}$ & $\mathbf{0}$ & $\mathbf{1}$ & $\mathbf{2}$ & $\mathbf{3}$ & $\mathbf{4}$ & $\mathbf{5}$ & $\mathbf{6}$ & $\mathbf{8}$ & $\mathbf{9}$ & $\mathbf{1 0}$ & $\mathbf{1 4}$ & $\mathbf{1 6}$ & $\mathbf{1 8}$ & $\begin{array}{c}\text { TOTAL } \\
\mathbf{n}(\%)\end{array}$ \\
\hline $\begin{array}{c}\text { ausente } \\
\text { ninhos }\end{array}$ & 4 & 3 & 2 & 2 & 2 & 1 & 1 & 3 & 0 & 0 & 2 & 2 & 2 & 24 \\
$(77,4)$
\end{tabular}

A expressão de MMP-9 na metástase esteve significativamente associada ao tipo da variante histológica no tumor primário. Saliente-se que os 7 casos com variante histológica que exibiam também metástase linfonodal demonstraram uma reação positiva de MMP-9 na lesão metastática. 


\subsubsection{Avaliação detalhada da expressão de MMP-14 no tumor primário e na metástase linfonodal}

As tabelas abaixo apresentam as associações significativas e com tendência à significância obtidas entre as variáveis clínico-patológicas e a reatividade de MMP-14 calculada pelo escore.

\subsubsection{Expressão global de MMP-14 no tumor primário}

Tabela 29 - Associação entre a imunoexpressão global de MMP-14 no tumor primário (escore) e o padrão arquitetural de invasão tumoral

\begin{tabular}{|c|c|c|c|c|c|c|c|c|c|c|c|c|c|c|}
\hline \multirow{2}{*}{$\begin{array}{c}\text { Padrão } \\
\text { arquitetural } \\
\text { de invasão }\end{array}$} & \multicolumn{13}{|c|}{ Escore - MMP-14 global } & \multirow{2}{*}{$\begin{array}{c}\text { TOTAL } \\
\text { n (\%) }\end{array}$} \\
\hline & 1 & 2 & 3 & 4 & 5 & 6 & 8 & 9 & 10 & 12 & 14 & 16 & 18 & \\
\hline nodular & 0 & 0 & 1 & 0 & 0 & 0 & 0 & 0 & 0 & 0 & 0 & 0 & 1 & $\begin{array}{c}2 \\
(3,3)\end{array}$ \\
\hline trabecular & 1 & 0 & 1 & 0 & 1 & 0 & 1 & 0 & 0 & 1 & 1 & 1 & 0 & $\begin{array}{c}7 \\
(11,7)\end{array}$ \\
\hline infiltrativo & 0 & 0 & 1 & 0 & 0 & 1 & 4 & 0 & 1 & 0 & 1 & 2 & 3 & $\begin{array}{c}13 \\
(21,7)\end{array}$ \\
\hline $\begin{array}{c}\text { misto, } \\
\text { infiltrativo } \\
\mathrm{e} \\
\text { trabecular }\end{array}$ & 2 & 8 & 4 & 1 & 0 & 4 & 0 & 1 & 3 & 5 & 3 & 2 & 0 & $\begin{array}{c}33 \\
(55)\end{array}$ \\
\hline $\begin{array}{c}\text { misto, } \\
\text { nodular e } \\
\text { trabecular }\end{array}$ & 0 & 1 & 0 & 0 & 1 & 0 & 0 & 0 & 0 & 1 & 0 & 2 & 0 & $\begin{array}{c}5 \\
(8,3)\end{array}$ \\
\hline $\begin{array}{c}\text { TOTAL } \\
\text { n (\%) }\end{array}$ & $\begin{array}{c}3 \\
(5)\end{array}$ & $\begin{array}{c}9 \\
(15)\end{array}$ & $\begin{array}{c}7 \\
(11,7)\end{array}$ & $\begin{array}{c}1 \\
(1,7)\end{array}$ & $\begin{array}{c}2 \\
(3,3)\end{array}$ & $\begin{array}{c}5 \\
(8,3)\end{array}$ & $\begin{array}{c}5 \\
(8,3)\end{array}$ & $\begin{array}{c}1 \\
(1,7)\end{array}$ & $\begin{array}{c}4 \\
(6,7)\end{array}$ & $\begin{array}{c}7 \\
(11,7)\end{array}$ & $\begin{array}{c}5 \\
(8,3)\end{array}$ & $\begin{array}{c}7 \\
(11,7)\end{array}$ & $\begin{array}{c}4 \\
(6,7)\end{array}$ & $\begin{array}{c}60 \\
(100)\end{array}$ \\
\hline
\end{tabular}

$x^{2}=74,539 p=0,022$

Assim como observado na MMP-2, a expressão IH global de MMP-14 no tumor primário apresentou uma associação significante com o padrão arquitetural de invasão, com destaque para os maiores valores do escore encontrados nos casos exibindo padrão infiltrativo. 


\subsubsection{Expressão de MMP-14 no epitélio neoplásico do tumor primário}

Tabela 30 - Associação entre a imunoexpressão de MMP-14 no epitélio neoplásico do tumor primário (escore) e o padrão arquitetural de invasão tumoral

\begin{tabular}{|c|c|c|c|c|c|c|c|c|c|c|c|c|c|c|c|c|}
\hline \multirow{2}{*}{$\begin{array}{c}\text { Padrão } \\
\text { arquitetural } \\
\text { de invasão }\end{array}$} & \multicolumn{15}{|c|}{ Escore - MMP-14 epitélio tumoral } & \multirow{2}{*}{$\begin{array}{c}\text { TOTAL } \\
\text { n (\%) }\end{array}$} \\
\hline & 0 & 1 & 2 & 3 & 4 & 5 & 6 & 7 & 8 & 9 & 10 & 12 & 14 & 16 & 18 & \\
\hline nodular & 0 & 1 & 0 & 0 & 0 & 0 & 0 & 0 & 0 & 0 & 0 & 0 & 0 & 0 & 1 & $\begin{array}{c}2 \\
(3,3)\end{array}$ \\
\hline trabecular & 1 & 0 & 0 & 1 & 1 & 1 & 0 & 0 & 1 & 0 & 0 & 1 & 1 & 0 & 0 & $\begin{array}{c}7 \\
(11,7)\end{array}$ \\
\hline infiltrativo & 0 & 1 & 0 & 1 & 0 & 1 & 2 & 0 & 2 & 0 & 0 & 0 & 1 & 2 & 3 & $\begin{array}{c}13 \\
(21,7)\end{array}$ \\
\hline $\begin{array}{c}\text { misto, } \\
\text { infiltrativo } \\
\text { e } \\
\text { trabecular }\end{array}$ & 0 & 5 & 7 & 4 & 1 & 0 & 4 & 1 & 0 & 1 & 3 & 3 & 2 & 2 & 0 & $\begin{array}{c}33 \\
(55)\end{array}$ \\
\hline $\begin{array}{c}\text { misto, } \\
\text { nodular e } \\
\text { trabecular }\end{array}$ & 0 & 1 & 0 & 0 & 0 & 1 & 0 & 0 & 0 & 0 & 0 & 1 & 0 & 2 & 0 & $\begin{array}{c}5 \\
(8,3)\end{array}$ \\
\hline $\begin{array}{c}\text { TOTAL } \\
\text { n (\%) }\end{array}$ & $\begin{array}{c}1 \\
(1,7)\end{array}$ & $\begin{array}{c}8 \\
(13,3)\end{array}$ & $\begin{array}{c}7 \\
(11,7)\end{array}$ & $\begin{array}{c}6 \\
(10)\end{array}$ & $\begin{array}{c}2 \\
(3,3)\end{array}$ & $\begin{array}{c}3 \\
(5)\end{array}$ & $\begin{array}{c}6 \\
(10)\end{array}$ & $\begin{array}{c}1 \\
(1,7)\end{array}$ & $\begin{array}{c}3 \\
(5)\end{array}$ & $\begin{array}{c}1 \\
(1,7)\end{array}$ & $\begin{array}{c}3 \\
(5)\end{array}$ & $\begin{array}{c}5 \\
(8.3)\end{array}$ & $\begin{array}{c}4 \\
(6,7)\end{array}$ & $\begin{array}{c}6 \\
(10)\end{array}$ & $\begin{array}{c}4 \\
(6,7)\end{array}$ & $\begin{array}{c}60 \\
(100)\end{array}$ \\
\hline
\end{tabular}

$x^{2}=79,704 p=0,045$

O estudo compartimentalizado da expressão de MMP-14 apenas no epitélio neoplásico do tumor primário mostrou associação estatisticamente significativa com a presença do padrão arquitetural infiltrativo que exibe os maiores valores do escore. Fato semelhante também foi observado nas expressões de MMP-2 e MMP-9 no epitélio, como descrito anteriormente. 


\subsubsection{Expressão de MMP-14 no estroma neoplásico do tumor}

\section{primário}

Tabela 31 - Associação entre a imunoexpressão de MMP-14 no estroma do tumor primário (escore) e o componente sarcomatoide

\begin{tabular}{|c|c|c|c|c|c|c|c|c|c|c|c|c|c|}
\hline \multirow{2}{*}{$\begin{array}{l}\text { Componente } \\
\text { sarcomatoide }\end{array}$} & \multirow[b]{2}{*}{0} & \multicolumn{11}{|c|}{ Escore - MMP-14 estroma } & \multirow{2}{*}{$\begin{array}{c}\text { TOTAL } \\
\text { n (\%) }\end{array}$} \\
\hline & & 1 & 2 & 3 & 4 & 5 & 6 & 8 & 10 & 14 & 16 & 18 & \\
\hline ausente & 2 & 13 & 11 & 6 & 0 & 1 & 4 & 8 & 4 & 1 & 1 & 0 & $\begin{array}{c}51 \\
(85)\end{array}$ \\
\hline presente & 0 & 0 & 1 & 1 & 1 & 0 & 1 & 1 & 2 & 0 & 1 & 1 & $\begin{array}{c}9 \\
(15)\end{array}$ \\
\hline $\begin{array}{c}\text { TOTAL } \\
\text { n (\%) }\end{array}$ & $\begin{array}{c}2 \\
(3,3)\end{array}$ & $\begin{array}{c}13 \\
(21,7)\end{array}$ & $\begin{array}{c}12 \\
(20)\end{array}$ & $\begin{array}{c}7 \\
(11,7)\end{array}$ & $\begin{array}{c}1 \\
(1,7)\end{array}$ & $\begin{array}{c}1 \\
(1,7)\end{array}$ & $\begin{array}{c}5 \\
(8,3)\end{array}$ & $\begin{array}{c}9 \\
(15)\end{array}$ & $\begin{array}{c}6 \\
(10)\end{array}$ & $\begin{array}{c}1 \\
(1,7)\end{array}$ & $\begin{array}{c}2 \\
(3,3)\end{array}$ & $\begin{array}{c}1 \\
(1,7)\end{array}$ & $\begin{array}{c}60 \\
(100)\end{array}$ \\
\hline
\end{tabular}

$x^{2}=18,462 p=0,071$

A expressão de MMP-14 no estroma apresentou tendência à associação com a presença do componente sarcomatoide no tumor primário, à semelhança ao anteriormente relatado com a MMP-2 e a MMP-9.

Tabela 32 - Associação entre a imunoexpressão de MMP-14 no estroma do tumor primário (escore) e a porcentagem do componente sarcomatoide

\begin{tabular}{|c|c|c|c|c|c|c|c|c|c|c|c|c|c|}
\hline \multirow{2}{*}{$\begin{array}{c}\text { Porcentagem } \\
\text { do } \\
\text { componente } \\
\text { sarcomatoide }\end{array}$} & \multicolumn{12}{|c|}{ Escore - MMP-14 estroma } & \multirow{2}{*}{$\begin{array}{c}\text { TOTAL } \\
\text { n (\%) }\end{array}$} \\
\hline & 0 & 1 & 2 & 3 & 4 & 5 & 6 & 8 & 10 & 14 & 16 & 18 & \\
\hline ausente & 2 & 13 & 11 & 6 & 0 & 1 & 4 & 8 & 4 & 1 & 1 & 0 & $\begin{array}{c}51 \\
(85)\end{array}$ \\
\hline $1-5 \%$ & 0 & 0 & 0 & 0 & 0 & 0 & 0 & 0 & 0 & 0 & 1 & 0 & $\begin{array}{c}1 \\
(1,7)\end{array}$ \\
\hline $6-10 \%$ & 0 & 0 & 0 & 1 & 1 & 0 & 0 & 0 & 0 & 0 & 0 & 0 & $\begin{array}{c}2 \\
(3,3)\end{array}$ \\
\hline $11-20 \%$ & 0 & 0 & 0 & 0 & 0 & 0 & 0 & 1 & 0 & 0 & 0 & 0 & $\begin{array}{c}1 \\
(1,7)\end{array}$ \\
\hline $21-30 \%$ & 0 & 0 & 1 & 0 & 0 & 0 & 0 & 0 & 0 & 0 & 0 & 0 & $\begin{array}{c}1 \\
(1,7)\end{array}$ \\
\hline $81-90 \%$ & 0 & 0 & 0 & 0 & 0 & 0 & 1 & 0 & 1 & 0 & 0 & 0 & $\begin{array}{c}2 \\
(3,3)\end{array}$ \\
\hline $91-100 \%$ & 0 & 0 & 0 & 0 & 0 & 0 & 0 & 0 & 1 & 0 & 0 & 1 & $\begin{array}{c}2 \\
(3,3)\end{array}$ \\
\hline $\begin{array}{c}\text { TOTAL } \\
\text { n (\%) }\end{array}$ & $\begin{array}{c}2 \\
(3,3)\end{array}$ & $\begin{array}{c}13 \\
(21,7)\end{array}$ & $\begin{array}{c}12 \\
(20)\end{array}$ & $\begin{array}{c}7 \\
(11,7)\end{array}$ & $\begin{array}{c}1 \\
(1,7)\end{array}$ & $\begin{array}{c}1 \\
(1,7)\end{array}$ & $\begin{array}{c}5 \\
(8,3)\end{array}$ & $\begin{array}{c}9 \\
(15)\end{array}$ & $\begin{array}{c}6 \\
(10)\end{array}$ & $\begin{array}{c}1 \\
(1,7)\end{array}$ & $\begin{array}{c}2 \\
(3,3)\end{array}$ & $\begin{array}{c}1 \\
(1,7)\end{array}$ & $\begin{array}{c}60 \\
(100)\end{array}$ \\
\hline
\end{tabular}


Dos 9 casos que apresentam componente sarcomatoide, 4 exibiram grande quantidade desse componente constituindo a neoplasia e 3 deles apresentaram um escore elevado ( $\geq 10$ ). Esses achados explicam a associação significante entre a expressão de MMP-14 no estroma e a porcentagem do componente sarcomatoide no tumor primário. Esse achado também foi observado na correlação dessa variável patológica com a expressão estromal de MMP-2, como descrito previamente.

\subsubsection{Expressão de MMP-14 na metástase linfonodal}

Tabela 33 - Associação entre a imunoexpressão de MMP-14 na metástase linfonodal (escore) e a porcentagem do componente sarcomatoide do tumor primário

\begin{tabular}{|c|c|c|c|c|c|c|c|c|c|c|c|c|c|}
\hline \multirow{2}{*}{$\begin{array}{c}\text { Porcentagem } \\
\text { do } \\
\text { componente } \\
\text { sarcomatoide }\end{array}$} & \multicolumn{12}{|c|}{ Escore - MMP-14 metástase linfonodal } & \multirow{2}{*}{$\begin{array}{c}\text { TOTAL } \\
\text { n (\%) }\end{array}$} \\
\hline & 0 & 1 & 2 & 3 & 4 & 5 & 6 & 8 & 10 & 12 & 14 & 16 & \\
\hline ausente & 3 & 3 & 6 & 2 & 1 & 5 & 1 & 0 & 1 & 1 & 1 & 0 & $\begin{array}{c}24 \\
(80)\end{array}$ \\
\hline $1-5 \%$ & 0 & 1 & 0 & 0 & 0 & 0 & 0 & 0 & 0 & 0 & 0 & 0 & $\begin{array}{c}1 \\
(3,3)\end{array}$ \\
\hline $11-20 \%$ & 1 & 0 & 0 & 0 & 0 & 0 & 0 & 0 & 0 & 0 & 0 & 0 & $\begin{array}{c}1 \\
(3,3)\end{array}$ \\
\hline $21-30 \%$ & 0 & 0 & 0 & 0 & 1 & 0 & 0 & 0 & 0 & 0 & 0 & 0 & $\begin{array}{c}1 \\
(3,3)\end{array}$ \\
\hline $81-90 \%$ & 0 & 0 & 0 & 0 & 0 & 0 & 0 & 1 & 0 & 0 & 1 & 0 & $\begin{array}{c}2 \\
(6,7)\end{array}$ \\
\hline $91-100 \%$ & 0 & 0 & 0 & 0 & 0 & 0 & 0 & 0 & 0 & 0 & 0 & 1 & $\begin{array}{c}1 \\
(3,3)\end{array}$ \\
\hline $\begin{array}{c}\text { TOTAL } \\
\text { n (\%) }\end{array}$ & $\begin{array}{c}4 \\
(13,3)\end{array}$ & $\begin{array}{c}4 \\
(13,3)\end{array}$ & $\begin{array}{c}6 \\
(20)\end{array}$ & $\begin{array}{c}2 \\
(6,7)\end{array}$ & $\begin{array}{c}2 \\
(6,7)\end{array}$ & $\begin{array}{c}5 \\
(16,7)\end{array}$ & $\begin{array}{c}1 \\
(3,3)\end{array}$ & $\begin{array}{c}1 \\
(3,3)\end{array}$ & $\begin{array}{c}1 \\
(3,3)\end{array}$ & $\begin{array}{c}1 \\
(3,3)\end{array}$ & $\begin{array}{c}2 \\
(6,7)\end{array}$ & $\begin{array}{c}1 \\
(3,3)\end{array}$ & $\begin{array}{c}30 \\
(100)\end{array}$ \\
\hline
\end{tabular}

A expressão IH de MMP-14 na metástase linfonodal mostrou-se significativamente associada à semiquantificação da extensão do componente sarcomatoide. Esse achado pode ser atribuído ao fato de que 5 dos 6 casos metastáticos que apresentaram componente sarcomatoide no tumor primário também foram positivos para MMP-14 na metástase linfonodal. 
5 DISCUSSÃO 
O presente estudo buscou caracterizar em uma série de 61 pacientes com o diagnóstico de carcinoma urotelial invasivo de bexiga, submetidos a cistectomia radical e linfadenectomia pelo grupo de Uro-oncologia da Divisão de Clínica Urológica do HCFMUSP e do ICESP, a associação entre variáveis anatomopatológicas observadas à histopatologia e à imunoexpressão das enzimas MMP-2, MMP-9 e MMP-14 através do estudo imuno-histoquímico.

Entendendo que os carcinomas uroteliais constituem um grupo complexo e heterogêneo houve, neste trabalho, o questionamento sobre possíveis diferenças na imunoexpressão das MMPs nos diferentes compartimentos do tumor. Assim, avaliamos não somente o epitélio tumoral, mas também o estroma adjacente que sustenta e interage de forma contínua com as células epiteliais do carcinoma, formando um microambiente que pode interferir, de forma favorável ou desfavorável, nos processos de crescimento tumoral.

A presente casuística é proveniente de espécimes cirúrgicos de cistectomias radicais com linfadenectomia regional, procedimento indicado para 0 tratamento principalmente de neoplasias no mínimo musculoinvasivas, onde tumores de alto grau constituem um dos principais achados. Por isso, esse trabalho visa estudar as variáveis morfológicas que, associadas às MMPs, podem se associar com maior progressão e potencial metastático linfonodal da neoplasia. 
Quanto ao método utilizado para avaliação da imunoexpressão das MMPs, optamos por uma escala semiquantitativa que compreendesse a intensidade e a extensão da positividade da reação, baseado no HSCORE descrito por McCarty et al. para a análise de receptor de estrogênio em câncer de mama (71). Metodologias semelhantes de estudo IH são descritos na literatura e utilizados na rotina para avaliação de fatores prognósticos do carcinoma de mama (72). Também para pesquisas, métodos que contemplam a intensidade e a positividade da reação IH são descritos em trabalhos que avaliaram marcadores de diferenciação neuroendócrina de tumores germinativos testiculares (73) e, mesmo recentemente, a imunoexpressão e MMP-2 e MMP-9, tanto no epitélio tumoral quanto no estroma de papilomas respiratórios recorrentes e carcinomas de laringe (74).

A técnica de TMA, que possibilitou o estudo de múltiplas amostras teciduais dos 61 pacientes da casuística organizadas em blocos de parafina, é reconhecida na literatura e utilizada também em estudos de carcinoma urotelial de bexiga (75-76). Ela permite a análise de centenas e até milhares de amostras de tumores de pacientes diferentes, locados em uma mesma lâmina, sob uma mesma padronização de reação $\mathrm{IH}$, gerando economia de custos materiais e de tempo para o pesquisador (77). 


\subsection{Aspectos epidemiológicos da casuística}

A presente série de carcinomas uroteliais invasivos de bexiga apresentou, em relação ao gênero, uma razão M:F de 5,1:1, demonstrando uma incidência maior de pacientes masculinos, mesmo quando comparadas com as estimativas de dados da base GLOBOCAM 2008 da própria população geral brasileira $(2,9: 1)$ (2) e mundial $(3,3: 1)$, segundo publicação

recente de Jemal et al (1). É possível que o predomínio do acometimento de homens desta série reflita os maiores fatores de risco para o carcinoma urotelial de bexiga (uso do tabaco e exposição ocupacional) que a população masculina assistida pelo HCFMUSP/ICESP possa estar submetida.

A faixa etária dos pacientes no momento da cistectomia radical variou entre 40 e 84 anos, tendo média de 65,4 \pm 10,9 anos e mediana de 67 anos, achado semelhante ao observado em estudo multicêntrico recente com 4430 pacientes (78).

\subsection{Associação das variáveis anatomopatológicas com a imunoexpressão das MMPs no tumor primário}

\section{Tamanho e focalidade da neoplasia}

O tamanho e a focalidade do tumor primário nas cistectomias radicais não demonstraram associações significativas com a imunoexpressão das MMPs. Isso não anula a importância dessas variáveis patológicas no que 
diz respeito a fatores prognósticos do carcinoma urotelial de bexiga. Van Rhijn et al., Nakai et al., Yossef e Lotan relatam a importância do tamanho e multifocalidade como fatores preditores principalmente de recorrência e progressão nos casos de carcinoma superficiais (pTa ou pT1) (79-81). Considerando neoplasias com estádio pT2, Fung et al. atestam que o tamanho do tumor exerce papel relevante como ferramenta prognóstica associada ao maior risco de metástase a distância (82).

\section{Grau histológico}

Quando avaliado o grau histológico, todos os 61 casos foram classificados com carcinomas de alto grau. Pelo fato de $100 \%$ dos casos preencherem uma única categoria, não foi possível demonstrar associações do grau histológico com a imunoexpressão das MMPs avaliadas. Vale ressaltar que nos casos de tumores pTa e pT1, o grau histológico é reconhecido como o principal fator prognóstico de progressão para doença musculoinvasiva, além de ser associado com o aumento do risco de mortalidade doença específica (22).

Estudos prévios comparando grau histológico e a presença de MMPs demonstram resultados contraditórios. Vasala et al. constataram que a expressão imuno-histoquímica de MMP-2 em carcinomas de bexiga não apresentou associação com o grau histológico, mas sim com a sobrevida doença específica (83). Grignon et al. também concluíram que mesmo a alta expressão de MMP-2 no epitélio dos carcinomas de bexiga também não se associou com o grau histológico (84). Kanayama et al., utilizando técnica de 
RT-PCR, verificaram que a maior expressão de MMP-2 correlacionou-se com o maior grau histológico e pior sobrevida dos pacientes (57). É provável que as diferenças entre os resultados obtidos possam ser atribuídos aos diferentes métodos utilizados.

\section{Tipo/configuração da neoplasia}

No presente trabalho, o tipo ou configuração da neoplasia predominante foi o não papilífero (sólido) com 55,7\% dos casos. Embora a classificação da OMS 2004 defina os tipos de tumores uroteliais como carcinomas invasivos e não invasivos (grupo no qual inclui os carcinomas papilíferos), a observação de rotina em uropatologia nos apresenta uma situação onde os tumores invasivos podem ainda exibir um componente papilífero (exofítico) em proporções variadas. Partindo desta observação, a opção em utilizar o achado dos carcinomas uroteliais papilífero versus não papilífero como uma variável anatomopatológica fez-se mandatória, apoiada em uma classificação também discutida por outros autores para neoplasias uroteliais (85), e que consta inclusive na última versão do protocolo para o exame de espécimes de pacientes com carcinoma de bexiga do Colégio de Patologistas Americanos (20). Outro fator que corroborou para a subdivisão do tipo histológico sob a forma adotada são as evidências moleculares de que a origem das neoplasias papilíferas parece estar associada à ativação da via MAPK por mutação do gene FGFR3. Os tumores papilíferos tendem a exibir menor recorrência, e a progressão do grau histológico é ditada por uma sequência de alterações acumuladas ao longo da carcinogênese 
urotelial, enquanto os tumores não papilíferos (sólidos) apresentam alterações moleculares ligadas à perda da função do gene TP53. Essas diferenças refletem no comportamento biológico e, consequentemente, no prognóstico das neoplasias uroteliais, atribuídas como de melhor evolução clínica quando tumores papilíferos, e com curso agressivo quando neoplasias sólidas (86-88).

No presente estudo, entretanto, a imunoexpressão das MMPs no tumor primário não mostrou associação com os tipos histológico, papilífero ou sólido. Esse dado reflete a constituição da casuística formada por carcinomas de alto grau no mínimo invasivos no plano muscular vesical, onde o componente sólido (seja na sua forma "pura" ou associada ao tipo papilífero) predominou quase que absolutamente, com 60 casos, em contraste com apenas um caso do tipo papilífero. Mesmo condensando os casos papilíferos em duas categorias baseadas na quantidade desse componente (ponto de corte $40 \%$ ), não se obteve associação com as MMPs.

\section{Diferenciação glandular}

No presente trabalho, mesmo exigindo como critério de inclusão o diagnóstico de carcinoma urotelial, encontramos áreas de diferenciação glandular em 6 casos $(9,8 \%)$. Outros estudos também referem a presença de focos de diferenciação glandular em aproximadamente $10 \%$ das neoplasias uroteliais, e reconhecem a importância desse tipo de diferenciação nos carcinomas uroteliais como um fator prognóstico desfavorável, possivelmente pela associação com neoplasias de alto grau (26). 
Outros trabalhos contestam seu significado, principalmente quando ajustado para o estádio da doença, embora seja demonstrada uma evolução adversa e pior resposta a tratamentos complementares de quimio/radioterapia (89). O nosso estudo não demonstrou associação significativa da presença de diferenciação glandular no carcinoma urotelial com o perfil de imunoexpressão das MMPs pesquisadas.

É reconhecido que a expressão $\mathrm{IH}$ de MMPs em tipos variados de adenocarcinomas está associada com a progressão da carcinogênese. Planagumà et al. constataram recentemente que a expressão IH de MMP-2 e MMP-9, com validação através de método de fluorescência, em adenocarcinomas endometrioides de endométrio e ovarianos, foi detectada de maneira predominante no citoplasma das células epiteliais e em menor quantidade nas células estromais. Assim, tal expressão se associa com o estadiamento tumoral, postulando a importância da distribuição das MMPs no fronte de invasão desse tipo de adenocarcinoma (90). Trudel et al., estudando a expressão IH de MMP-9 em uma série de adenocarcinomas prostáticos e comparando a reatividade no epitélio tumoral, no estroma e nas glândulas prostáticas benignas, concluíram que os maiores índices de imunoexpressão de MMP-9 pelas células do adenocarcinoma prostático estiveram associadas com tumores com alto escore de Gleason $(\geq 8)$, porém não demonstraram relação com a sobrevida livre de doença (91). Para elaboração do presente trabalho, não encontramos estudos que contemplam a imunoexpressão de MMPs em carcinomas uroteliais com diferenciação glandular ou mesmo adenocarcinomas da bexiga. A falta de significância 
aqui observada para essa variável anatomopatológica pode refletir a baixa frequência da diferenciação glandular já documentada na literatura médica, e que aqui também se fez presente.

\section{Presença de variantes histológicas}

$\mathrm{Na}$ presente série, 13 casos $(21,3 \%)$ apresentaram algum tipo de variante histológica do carcinoma urotelial, tendo as variantes formadoras de ninhos (4 casos), a variante micropapilífera (3 casos) e as células claras/ricas em glicogênio (3 casos) como as mais prevalentes, além dos tipos células pequenas, padrão invertido e linfoepitelioma-símile, representadas por 1 caso cada. A discussão sobre a importância de se reconhecer e relatar essa característica morfológica dos carcinomas uroteliais é bem estabelecida na literatura uropatológica, pois abrange inúmeros diagnósticos diferenciais com outros tumores malignos e com lesões uroteliais benignas, além de exibir implicações clínicas relevantes ao paciente $(26,92)$. Ao considerarmos a variante formadora de ninhos, o principal problema é o seu não reconhecimento como uma neoplasia maligna, podendo ser confundida com lesões uroteliais não neoplásicas como uma hiperplasia florida dos ninhos de von Brunn. A variante de células pequenas é uma neoplasia de alto grau morfologicamente idêntica ao carcinoma indiferenciado de células pequenas do pulmão, inclusive com diferenciação neuroendócrina. Segundo estudo envolvendo 64 pacientes com essa variante publicado por Cheng et al., $66 \%$ dos casos submetidos à cistectomia radical exibiram metástase linfonodal e a sobrevida doença 
específica observada foi de $56 \%$ em 1 ano e $16 \%$ em 5 anos (93). Merece destaque a variante micropapilífera, pois a sua presença com frequência está associada à metástase linfonodal e baixa resposta à imunoterapia, de forma que alguns autores discutem inclusive a indicação de cistectomia radical precoce em casos de tumores pTa e pT1 como tratamento de pacientes com essa variante $(89,94)$.

O presente estudo não demonstrou associação entre as variantes histológicas observadas e a expressão de MMPs no tumor primário, a nosso ver devido ao pequeno grupo de pacientes apresentando cada tipo específico dessas variantes. Podemos especular que outras vias carcinogênicas estejam relacionadas ao desenvolvimento de uma variante morfológica nos carcinomas uroteliais. Ou ainda, que, na fase de progressão neoplásica já estabelecida, a função das MMPs seja suplantada por outras enzimas quando consideradas as variantes morfológicas.

\section{Invasão neoplásica linfovascular}

A importância prognóstica da ILV nos carcinomas uroteliais de bexiga é bem estabelecida. Quando presente em espécimes de RTUTB está associada com maior risco de metástase linfonodal, estádios patológicos mais avançados na cistectomia radical, maior probabilidade de quimioterapia adjuvante, além de menor sobrevida média e sobrevida livre de doença quando comparada com os casos de invasão negativa (33). Nos casos submetidos à cistectomia radical, também está relacionada à sobrevida livre de recorrência nos pacientes pT3pN0, podendo ser 
considerada como um parâmetro de inclusão ou exclusão de pacientes candidatos a tratamentos adjuvantes (95).

As MMPs estão associadas à angiogênese seja por degradarem a MEC, com liberação de fatores de crescimento angiogênico ligados a esta, por regularem a função de fatores de crescimento vascular ou por clivarem a adesão entre células endoteliais (96-97). Porém, ao associarmos a presença ou não detecção da ILV na nossa casuística com a imunoexpressão de MMPs no tumor primário, não houve significância estatística, mesmo estando presente em 48 casos (78,7\%). Quiçá a ILV seja mais dependente de fatores angiogênicos ou linfangiogênicos ou mesmo de elementos que permitam às células neoplásicas condições de sobrevivência no ambiente intravascular do que da ação de metaloproteinases. Estudos futuros com maior casuística, com a discriminação do padrão de invasão com uso de marcadores imunohistoquímicos para melhor caracterização de vasos linfáticos (D2-40) e sanguíneos (CD31 e actina de músculo liso) e, em especial, com o acompanhamento clínico de pacientes para posterior subdivisão dos casos conforme o surgimento de metástases por via sanguínea, o tempo até o surgimento das metástases e o tempo de sobrevida total e livre de neoplasia, poderão abordar com mais propriedade esta questão.

\section{Invasão neoplásica perineural}

Embora a importância da invasão neoplásica perineural nos carcinomas uroteliais da bexiga seja controversa e já reconhecida em nosso meio por não estar associada à sobrevida doença específica (através de 
análise multivariável) nos pacientes com cistectomia radical (98), a opção por incluir essa variável anatomopatológica no nosso estudo deve-se ao fato do trabalho ser fundamentado em achados de patologia cirúrgica da bexiga. Uma observação curiosa foi a frequência relativamente elevada da detecção de invasão perineural na nossa casuística (38 casos - 62,3\%), achado maior que em estudos prévios relatados, nos quais variam entre $6,8 \%$ e $47,7 \%$ (98). Mesmo com 38 casos exibindo a invasão perineural, nenhuma associação significativa foi observada com a expressão das MMPs, talvez devido à baixa importância desse achado morfológico no que diz respeito aos fatores de impacto do carcinoma urotelial, ou porque os endpoints mais adequados para tal avaliação sejam os critérios clínicos que referimos anteriormente quanto à invasão vascular.

\section{Carcinoma in situ}

De maneira semelhante à invasão perineural, a presença de 28 casos $(45,9 \%)$ com CIS na mucosa vesical também não demonstrou associações significativas com as MMPs pesquisadas no tumor primário invasivo. Uma possibilidade para o futuro é demonstrar se a imunoexpressão de MMPs no próprio CIS tem associação com as outras variáveis morfológicas da neoplasia invasiva. Isso poderia acontecer uma vez que a presença de CIS é considerada o segundo fator prognóstico mais importante associado à progressão para doença musculoinvasiva, após o grau histológico, e que nos casos não tratados a história natural da doença estima que aproximadamente $54 \%$ dos pacientes progridem para tumores $\mathrm{pT} 2$ (27). 


\section{Estádio tumoral}

Entre as três diferentes maneiras pelas quais analisamos o estádio tumoral da presente série e sua associação com as MMPs, observamos significância apenas na imunoexpressão de MMP-9 no epitélio neoplásico e o estádio tumoral agrupando os casos pT2 + pT3 versus pT4 $(p=0,049)$. Também constatamos que a tendência verificada na expressão global de MMP$9(p=0,077)$ deve ser principalmente decorrente da expressão no epitélio neoplásico. Quando usamos a classificação AJCC/TNM 2009, uma forte tendência à significância foi demonstrada com a imunoexpressão de MMP-9 no estroma $(p=0,05)$. Considerando que a casuística retrata apenas neoplasias de alto grau histológico estadiadas como musculoinvasivas ou localmente avançadas, é possível compreender por que não observarmos associações mais robustas no que diz respeito ao estádio e expressão IH de MMPs.

Por ser o estádio patológico considerado o mais importante determinante de prognóstico e tratamento para o carcinoma de bexiga (21, 99), um dos desdobramentos do nosso trabalho poderá ser a pesquisa das MMPs em carcinomas uroteliais pTa ou pT1 e sua possível associação com o estádio. Davies et al. demonstraram por análise zimográfica que maiores níveis de MMP-2 e MMP-9 estiveram associados com tumores invasivos quando comparados com os superficiais (100). Utilizando a metodologia imuno-histoquímica em tecido em parafina, Vasala et al. constataram que a imunoexpressão de MMP-2 em 54 carcinomas primários de bexiga se correlacionou com o estádio patológico $(p=0,04)$ e com a sobrevida doença específica em 5 anos (55\% para os pacientes com MMP-2 positiva versus 
77\% com MMP-2 negativa) (83). Ao contrário do que apresentaram previamente, os mesmos autores também demonstraram por IH que a maior imunoexpressão de MMP-9 no tecido associou-se com melhor sobrevida geral e livre de recorrência do carcinoma de bexiga (101). Uma casuística maior, incluindo tumores superficiais e o desfecho clínico dos pacientes, poderá responder questões relacionadas às MMPs e ao estádio patológico na nossa população. O conhecimento do papel das MMPs em degradar a MEC e promover a invasão tumoral sugere uma lógica da sua importância nos tumores mais invasivos.

\section{Metástase linfonodal}

O presente estudo também pesquisou a imunoexpressão de MMPs nos tumores primários com aspectos da metástase linfonodal, contemplando não só o estádio pN (ausência ou presença de metástase) mas também o tamanho do depósito tumoral e sua extensão extranodal. Considerando essas variáveis morfológicas, não observamos associações significativas com as MMPs estudadas. Talvez pudéssemos esperar uma associação positiva entre essas variáveis, visto que as MMPs estão intimamente relacionadas à degradação da membrana basal, destruição da matriz extracelular, invasão do estroma e promoção da angiogênese, sendo uma das principais enzimas responsáveis pela progressão e desenvolvimento de metástases. Através do uso de modelos animais, a atividade de MMP-2 e de MMP-9 já foi encontrada fortemente associada à capacidade de desenvolvimento de metástases em células do câncer de bexiga (102). Em 
uma análise multivariável, Slaton et al. demonstraram por hibridização in situ que o aumento da relação MMP-9/E-caderina foi um fator prognóstico independente de mortalidade doença específica nos pacientes com carcinoma de bexiga localmente avançado, tratados com cistectomia radical e quimioterapia, sugerindo um papel importante entre a interação da MMP-9 com a E-caderina na progressão e metástase de tumores uroteliais (66).

\section{Atipia nuclear}

Como no presente estudo todos os casos exibiram alto grau histológico, devido principalmente aos distúrbios arquiteturais dessas neoplasias, a avaliação da atipia nuclear revestiu-se de especial importância, discriminando mesmo nesse grupo de carcinomas invasores um subgrupo de fenótipo mais anaplásico. A atipia nuclear dos carcinomas de diversos órgãos sólidos influencia diretamente outras características morfológicas da neoplasia, como o grau histológico. Tomando como exemplo o sistema de graduação histológica do carcinoma de mama (sistema de Nottingham), o grau nuclear do tumor, em conjunto com índice mitótico e formação tubular neoplásica, constitui elemento fundamental para formulação de um escore que está relacionado com o comportamento biológico do câncer, características moleculares e o prognóstico dos pacientes (103).

No presente trabalho, 45 casos $(73,8 \%)$ foram classificados como atipia nuclear intensa. Observando as MMPs estudadas, encontramos associação significativa entre a atipia nuclear e a imunoexpressão no estroma tumoral de MMP-2 (22 casos positivos; $p=0,032$ ) e MMP-9 (52 casos positivos; 
$p=0,031)$. Se por um lado o núcleo da célula epitelial reflete o funcionamento da "máquina celular", poderíamos esperar valores significativos das MMPs também no compartimento epitelial do carcinoma. De fato, esse não foi o nosso achado. Como já discutido anteriormente, a expressão e MMPs ocorre tanto no epitélio tumoral como no estroma (55). Podemos aventar a hipótese de que esse achado reforça a interação epitéliomesênquima que ocorre nos processos neoplásicos, onde a expressão de MMPs e outras enzimas pelo estroma influenciam características morfológicas da célula epitelial, ou ainda o contrário: estímulos que partem do epitélio neoplásico promovem uma resposta estromal que estimula a expressão de MMPs pelos vasos sanguíneos e fibroblastos do estroma, que por sua vez facilitam a degradação da matriz extracelular e a progressão da neoplasia.

\section{Diferenciação escamosa}

A presença de diferenciação escamosa foi detectada em 8 de nossos casos $(13,1 \%)$, um pouco abaixo da frequência relatada na literatura, que varia entre $16 \%$ e $25 \%$. Importa salientar que, no presente estudo, foram excluídos os carcinomas epidermoides puros, pois, enquanto trabalhávamos com a hipótese de que neoplasias uroteliais poderiam exibir diferenciação divergente durante a carcinogênese, compreendemos que não seria possível distinguir se os casos de carcinomas integralmente epidermoides seriam resultado de uma completa diferenciação divergente ou se seriam neoplasias desde o início diferentes das uroteliais (como nos casos de 
carcinomas epidermoides secundários à infecção crônica por parasitas). A frequência de diferenciação divergente aumenta de acordo com o grau e o estádio da neoplasia, além da proporção do componente escamoso ser bastante variável, podendo ser detectado de pequenas a grandes extensões nos carcinomas uroteliais $(92,104)$. Nos tumores invasivos, a presença do componente escamoso indica uma resposta menos favorável ao tratamento, enquanto que nos tumores de baixo grau e pTa/pT1 a presença de componente escamoso foi anteriormente relacionada a maiores taxas de recorrência (105).

Os achados do presente estudo demonstraram uma associação da diferenciação escamosa com a imunoexpressão global de MMP-9 ( $p$ = 0,033), e uma tendência à significância no caso da expressão de MMP-2 no estroma $(p=0,062)$. No caso da MMP-9, é marcante o fato de que todos os 8 casos com diferenciação escamosa demonstraram uma reação IH positiva para o anticorpo, inclusive com 1 caso alcançando o escore 18. Estudando a MMP-2 no estroma, a tendência à associação também pode ser explicada pelo fato do maior escore observado no estroma (escore 3) ter sido detectado em um caso onde a diferenciação escamosa esteve presente.

\section{Padrão arquitetural de invasão tumoral}

Com base nos padrões arquiteturais de invasão tumoral reconhecidos em espécimes de cistectomias radicais por Jimenez et al. (24), dividimos as neoplasias da nossa casuística em 6 subgrupos, conforme descrito nos Métodos do trabalho, e pesquisamos as associações com as MMPs. Dentre 
os subgrupos, o padrão infiltrativo foi o mais frequente, com 13 casos $(21,3 \%)$ na forma predominante e em 33 casos $(54,1 \%)$ associado ao padrão trabecular. Este é um dado importante, pois a presença do padrão infiltrativo nos carcinomas de bexiga está associada com maior recorrência e uma sobrevida mediana menor quando comparada com os padrões nodular e trabecular.

Para nossa surpresa, essa variável anatomopatológica demonstrou resultados consistentes e significativos nas três MMPs em questão. Os resultados obtidos com a imunoexpressão global $(p=0,022)$ e no epitélio tumoral $(p=0,005)$ para a MMP-2 foram próximos dos observados na avaliação global $(p=0,022)$ e no epitélio $(p=0,045)$ de MMP-14. Considerando a imunoexpressão da MMP-9, resultados significativos foram obtidos em ambos os compartimentos da neoplasia: epitélio $(p=0,043)$ e estroma $(p=0,044)$. Atribuímos esses valores ao fato da presença do padrão arquitetural infiltrativo sempre apresentar as maiores frequências e os maiores escores obtidos nas três MMPs.

Esses achados constatam a associação entre a expressão de MMPs no estroma e no epitélio do tumor e o padrão infiltrativo de invasão tumoral. Se a presença do padrão infiltrativo é reconhecida como um fator de impacto ruim com diminuição da sobrevida, a sua associação com as imunoexpressões de MMP-2, MMP-9 e MMP-14 observadas no presente trabalho fortalecem a importância das MMPs na progressão dos carcinomas de bexiga, pelo fato de estarem relacionadas a essa forma mais agressiva de neoplasia. 


\section{Componente sarcomatoide}

O componente sarcomatoide do carcinoma urotelial foi detectado em 9 de nossos casos $(14,8 \%)$, com a sua proporção variando de um achado focal ( 1 caso) até extensas áreas ( 2 casos com mais de $90 \%$ do tumor). Associando essa variável anatomopatológica com a imunoexpressão de MMPs, observamos associações significativas da MMP-9 no estroma ( $p=$ 0,036) e tendência à significância da imunorreatividade estromal tanto da MMP-2 $(p=0,062)$ como na MMP-14 $(0,071)$. Considerando a semiquantificação do componente sarcomatoide no tumor primário (porcentagem sarcomatoide), obtemos um resultado ainda mais robusto, onde todas as três MMPs apresentaram associação das suas respectivas imunoexpressões detectadas no estroma (MMP-2: $p=0,003$; MMP-9: $p=0,013$ e MMP-14: $p<0,001)$. Analisando os resultados obtidos na MMP-2, observamos que dos 9 casos totais com componente sarcomatoide, 5 foram positivos, inclusive 1 caso exibindo o escore 3 (maior valor detectado no estroma para MMP-2). Em relação à MMP-9 e MMP-14, todos os 9 casos que apresentaram o componente sarcomatoide demonstraram reação positiva para os anticorpos das MMPs e, considerando a quantidade desse componente no tumor primário, 4 casos exibiram neoplasias constituídas por mais de $80 \%$ do componente.

Segundo a literatura, neoplasias de bexiga diagnosticadas como carcinoma sarcomatoide ou carcinossarcoma são raras (26). Pela classificação da OMS 2004, carcinoma sarcomatoide é o termo recomendado para a nomenclatura desses tumores, que são definidos como 
uma neoplasia maligna bifásica com evidências de diferenciação epitelial e mesenquimal. É provável que o maior número de casos observados na nossa casuística seja resultado do reconhecimento à histopatologia de um componente sarcomatoide caracterizado por células indiferenciadas e/ou fusiformes, mesmo quando presente em pequenas proporções, e por se tratar de neoplasias de alto grau obtidas em cistectomia radical. Geralmente são neoplasias com estádio já avançado no momento do diagnóstico. Em uma série de 26 casos de carcinoma sarcomatoide, Lopez-Beltran et al. constataram apenas 1 caso como pT2, e todos os demais como pT3/pT4 (106). Em outro estudo com 18 casos, Torenbeeck et al. relatam 44\% da casuística como pT2 e $56 \%$ sendo pT3/pT4 (107). A sobrevida média dos pacientes com carcinoma sarcomatoide também é menor quando comparada com o carcinoma urotelial convencional, alcançando apenas 10 meses na série de Lopez-Beltran. Em recente estudo a partir de dados de registro populacional de pacientes dos Estados Unidos da América, a sobrevida média de pacientes com carcinoma sarcomatoide calculada para 1, 5 e 10 anos foi de $53,9 \%, 28,4 \%$ e $25,8 \%$, respectivamente, e, no modelo de análise de sobrevida multivariável, apenas o estádio tumoral foi identificado com fator prognóstico independente associado à sobrevida câncer específica (108).

Há duas correntes que tentam justificar a origem do carcinoma sarcomatoide. A teoria monoclonal advoga que ambos os elementos (carcinomatoso e sarcomatoso) são derivados de uma única célula-tronco pluripotente que, em subsequência, desenvolve uma diferenciação divergente nos sentidos epitelial e mesenquimal. A outra teoria, a multiclonal, defende 
que o carcinoma sarcomatoide seja um tumor de colisão composto por dois elementos diferentes que derivam de duas ou mais células-tronco distintas, originando separadamente um elemento epitelial e outro mesenquimal.

Através de estudos em modelos de carcinogênese, tenta-se explicar a origem do fenótipo mesenquimal nos carcinomas sarcomatoides. Uma explicação seria a reprogramação celular, induzida por sinais extracelulares do microambiente estromal, que resultaria na transdiferenciação do fenótipo epitelial para mesenquimal das células do carcinoma (109). O que marca a transição epitélio-mesenquimal (TE-M) é a perda de E-caderina pelas células epiteliais (responsável pelas junções intercelulares) e aquisição de marcadores típicos de uma célula mesenquimal (p. ex. vimentina e fibronectina) $(62,110)$. Utilizando a técnica de $\mathrm{IH}$, Ikegami et al. estudaram 14 casos de carcinoma sarcomatoide da bexiga e compararam a expressão de proteínas de adesão celular (E-caderina, CD44 e CD44v6) nos componentes sarcomatoide e carcinomatoso, demonstrando a menor expressão dessas proteínas de adesão nas áreas sarcomatoides das neoplasias (111).

Estudos in vitro demonstram que a TE-M é um processo dinâmico onde está envolvido grande número de vias sinalizadoras, dentre elas fatores de crescimento celular, citocinas e as próprias MMPs (112). Através da TE-M, as células do carcinoma podem adquirir maior mobilidade, facilitando sua migração pela matriz extracelular, que culmina com maior potencial de invasão tumoral. Matsui et al., estudando a ação de integrina ligada a quinase, demonstraram em linhagem de células de carcinoma de bexiga que a maior expressão de MMP-9 e a menor expressão de 
E-caderina estão associadas com maior invasão das células neoplásicas e capacidade de assumir a TE-M por essas células (113).

Esses achados demonstram a associação das MMPs nos processos de invasão tumoral, influenciando também na TE-M, que morfologicamente se traduz pelo fenótipo mesenquimal dos carcinomas uroteliais, que por sua vez foi constatado na nossa série de casos pela associação do componente sarcomatoide com a imunoexpressão das três MMPs estudadas.

Demonstrando também que as MMPs são sintetizadas tanto pelo epitélio neoplásico como pelo estroma adjacente, Wallard et al. caracterizaram por RT-PCR e microdissecção a laser os níveis de expressão de 24 MMPs humanas diferentes, estudando a expressão do RNA no epitélio e no estroma de amostras de urotélio normal e neoplásico (55). Dentre as MMPs que apresentaram altos níveis de expressão, destacaram-se as MMP2, MMP-14 e MMP-9. Em relação à localização, a MMP-2 e MMP-14 demonstraram maior expressão no estroma tumoral, enquanto a MMP-9 exibiu valores iguais de expressão no estroma e no epitélio neoplásico. Outro dado relevante desse mesmo trabalho foi a associação positiva entre a expressão de MMP-2 e MMP-14 com o maior grau histológico das neoplasias estudadas. Embora a metodologia utilizada por Wallard et al. seja diferente da empregada por nós, os resultados aqui demonstrados convergem para um mesmo sentido: as MMPs são expressadas em compartimentos diferentes da neoplasia.

Retornando ao nosso trabalho, um aspecto curioso que foi observado foi que a imunoexpressão das MMPs por vezes exibia maior reatividade na 
interface direta das células epiteliais com o estroma adjacente, reforçando essa interação epitélio-estroma. Outro aspecto que vale ser comentado é a observação de que a maioria das associações e/ou tendências significativas que encontramos entre as variáveis anatomopatológicas e a imunoexpressão de MMP-2 e MMP-14 nos tumores primários da nossa casuística demonstraram que, para uma mesma variável, essas enzimas tiveram sua imunoexpressão detectada em um mesmo compartimento, visto o componente sarcomatoide no estroma, reforçando a interação entre essas duas enzimas e a função da MMP-14 em participar da ativação da MMP-2 na superfície celular (114)

\subsection{Associação das variáveis anatomopatológicas com a imunoexpressão das MMPs na metástase linfonodal}

As associações entre as variáveis anatomopatológicas previamente descritas e a imunoexpressão das MMP-2, MMP-9 e MMP-14 na metástase linfonodal também foram avaliadas. Como referido na seção dos Métodos do trabalho, a imunorreatividade dessas enzimas no linfonodo foi avaliada apenas sob a forma global, que inclui o depósito de células epiteliais do carcinoma urotelial e o estroma dentro do linfonodo. Outro ponto a salientar é que, dos 34 casos metastáticos, 2 foram classificados como micrometástase pelos critérios de medida. Ambos os casos estavam presentes nos cortes de TMA submetidos à pesquisa de MMP-2, mas para MMP-9 e MMP-14, 
apenas um caso foi representativo. Em todas as situações que foram possíveis as avaliações da imunoexpressão das MMPs nas micrometástases, o resultado foi negativo. Se por um lado ficamos limitados pelo pequeno número de casos de micrometástase, por outro nos chama a atenção de que, quando a reação foi possível, as MMPs não foram expressas, sugerindo que o tamanho da metástase linfonodal possa estar associado com a expressão de MMPs distante do tumor primário, seja por falta de estroma suficiente para a interação com o epitélio, seja pela pequena quantidade de células epiteliais na própria metástase, insuficiente para o autoestímulo da produção.

Ao analisarmos o tipo da variante histológica no tumor primário e a imunoexpressão de MMP-9 no linfonodo, observamos uma associação significativa $(p=0,021)$. Os 7 casos com alguma variante histológica e que também apresentavam doença metastática foram positivos para a imunoexpressão de MMP-9. Uma possibilidade é que, além da progressão, a maior expressão de MMP-9 possa estar associada com o potencial metastático dos carcinomas uroteliais, incluindo formas morfológicas específicas da neoplasia.

A porcentagem do componente sarcomatoide também demonstrou associação significativa com a expressão de MMP-14 no linfonodo ( $p=0,017)$. Esse achado pode ser atribuído ao fato de que 5 dos 6 casos metastáticos que apresentaram componente sarcomatoide no tumor primário também foram positivos para MMP-14 na metástase linfonodal. Esse dado corrobora o que discutimos acima, sobre como o fenótipo sarcomatoide do tumor 
proporciona um maior potencial de invasão e metástase dos carcinomas por ação também de MMPs, seja por quebra da membrana basal, degradação de elementos da MEC, facilitação da invasão da parede de vasos sanguíneos e linfáticos ou por regulação da angiogênese (48). Se em processos fisiológicos é documentada a importância da MMP-9 e MMP-14 na angiogênese (115-116), em modelos animais de tumores há trabalhos demonstrando a diminuição da expressão de MMP-2 e consequentemente a redução da angiogênese (117). Esses são dados que apontam a função próangiogênica das MMPs.

Dentre as variáveis que apresentaram uma tendência à significância, destaca-se o tipo/configuração da neoplasia que mostrou uma associação quase significante com a MMP-2 $(p=0,07)$ e com a MMP-9 $(0,072)$, e a atipia nuclear com a MMP-9 ( $p=0,083)$. Quanto ao tipo/configuração, praticamente toda a casuística demonstrou o tipo não papilífero (sólido) nas neoplasias, seja na sua forma pura ou mista, que confere uma pior evolução quando comparada com as formas papilíferas puras. O grau nuclear que reflete diretamente o grau histológico da neoplasia também pode estar associado com a maior expressão de MMP nas metástases por uma capacidade das neoplasias mais pleomórficas de sobreviverem distante do tumor primário.

As variáveis anatomopatológicas de invasão linfovascular e metástase linfonodal não demonstraram associações, pois 100\% dos casos preencheram uma única categoria (todos os casos com metástase linfonodal apresentaram ILV no tumor primário), não sendo possível demonstrar associações com a imunoexpressão das MMPs avaliadas. 
Apoiados nas nossas observações e nos trabalhos publicados que foram a base das nossas consultas para a elaboração do estudo sobre as MMPs na progressão e metástase dos carcinomas uroteliais de bexiga, fica a possibilidade do reconhecimento de aspectos anatomopatológicos como variáveis capazes de identificar um subgrupo de tumores de bexiga onde as MMPs poderiam auxiliar no uso mais efetivo da terapêutica para esse tipo de câncer. 
6 CONCLUSÕES 
1) A seleção morfológica de áreas representativas dos carcinomas uroteliais primários de bexiga e de suas respectivas metástases linfonodais, assim como sua distribuição em amostras de TMA, permitiu o estudo imuno-histoquímico, demonstrando associações da imunoexpressão de MMP-2, MMP-9 e MMP-14 com variáveis anatomopatológicas indicativas de progressão tumoral. Coletivamente, tais achados destacam a importância do estudo detalhado da distribuição destas metaloproteinases de matriz tanto no epitélio neoplásico quanto no estroma.

2) A presença do padrão arquitetural infiltrativo mostrou-se diretamente relacionada à maior imunoexpressão de MMP-2, MMP-9 e MMP-14 no epitélio neoplásico. O padrão infiltrativo também apresentou relação com a expressão de MMP-9 no estroma. Esses achados demonstram a importância das MMPs estudadas por promover a degradação da matriz extracelular, facilitar a mobilidade tumoral e favorecer o desenvolvimento do fenótipo infiltrativo nos carcinomas uroteliais.

3) A presença do componente sarcomatoide foi associada com maior expressão IH de MMP-2, MMP-9 e MMP-14 no estroma do tumor, indicando uma associação entre a transição epitélio-mesênquima nos 
carcinomas uroteliais de bexiga, traduzida morfologicamente pela presença do componente sarcomatoide, e a imunoexpressão das MMPs pelo estroma.

4) A presença de diferenciação escamosa associou-se de forma significativa com a reatividade global de MMP-9 e demonstrou uma tendência à significância com a imunoexpressão de MMP-2 no estroma, indicando que as MMPs exercem função nas diferenciações divergentes do carcinoma urotelial.

5) A presença de atipia nuclear intensa está associada com maior expressão IH de MMP-2 e MMP-9 no estroma, indicando uma possível interação entre o epitélio neoplásico pleomórfico com o microambiente tumoral.

6) O estadiamento tumoral conforme a classificação AJCC/TNM 2009 demonstrou forte tendência de associação com a imunoexpressão de MMP-9 no estroma. A associação tornou-se significante com a imunoexpressão de MMP-9 no epitélio e o estádio tumoral agrupado (pT2 + pT3 vs pT4). Esses achados demonstram que a maior expressão de MMP-9 ocorre já no estádio de doença musculoinvasiva, indicando a função da MMP-9 na progressão do estádio para doença localmente avançada. 
7) A presença de tipos específicos de variantes histológicas do carcinoma urotelial na cistectomia radical demonstrou associação significativa com a imunoexpressão de MMP-9 na metástase linfonodal, sugerindo um papel da MMP na metastatização de formas histológicas mais agressivas do carcinoma urotelial.

8) A associação significativa entre a porcentagem do componente sarcomatoide no tumor primário e a expressão de MMP-14 na metástase linfonodal indica uma função da MMP no processo de disseminação metastática do carcinoma urotelial, principalmente quando esse componente é um elemento que predomina na neoplasia primária. 


\section{ANEXOS}




\section{Anexo A: Protocolo de estudo anatomopatológico}

1. Tamanho (T) do maior foco neoplásico:

1) até $1,0 \mathrm{~cm}$; 2) $1,1-2,0 \mathrm{~cm}$; 3) $2,1-3,0 \mathrm{~cm}$;) $3,1-4,0 \mathrm{~cm}$; 5) $4,1-5,0 \mathrm{~cm}$; 6 ) $5,1-6,0 \mathrm{~cm}$; 7) 6,1 - 7,0 cm; 8) 7,1 - 8,0 cm, 9) 8,1 - 9,0 cm, 10) $9,1-10,0 \mathrm{~cm}$; 11) Maior que $10,0 \mathrm{~cm}$; 99) dado não disponível.

2. Multifocalidade:

1) não; 2) sim; 99) dado não disponível.

3. Grau histológico (OMS, 2004):

1) baixo; 2) alto.

4. Tipo/configuração da neoplasia:

1) papilífero; 2) não papilífero (sólido); 3) misto.

5. Porcentagem do tipo papilífero:

1) ausente; 2) $1-10 \%$; 3) $11-20 \%$; 4) $21-30 \%$; 5) 31-40\%; 6) $41-50 \%$; 7) $51-$ $60 \%$; 8) 61-70\%; 9) 71-80\%; 10) 81-90\%; 11) $91-100 \%$.

6. Padrão arquitetural de invasão tumoral:

1) nodular; 2) trabecular; 3) infiltrativo;

4) misto, trabecular + infiltrativo;

5) misto, trabecular + nodular;

6) misto, infiltrativo + nodular.

7. Atipia nuclear:

1) leve; 2) moderada; 3) intensa.

8. Componente sarcomatoide:

1) ausente; 2) presente.

9. Porcentagem de componente sarcomatoide:

1) ausente; 2) $1-5 \%$; 3) $6-10 \%$; 4) $11-20 \%$; 5) $21-30 \%$; 6) $31-40 \%$; 7) $41-$ $50 \%$; 8) $51-60 \%$; 9) 61-70\%; 10) $71-80 \%$; 11) $81-90 \%$; 12) $91-100 \%$.

10. Diferenciação escamosa:

1) ausente; 2) presente.

11. Porcentagem de diferenciação escamosa:

1) ausente; 2) $1-10 \%$; 3) $11-20 \%$; 4) $21-30 \%$; 5) $31-40 \%$; 6) $41-50 \%$; 7) $51-$ $60 \%$; 8) $61-70 \%$; 9) $71-80 \%$; 10) $81-90 \%$; 11) $91-100 \%$.

12. Diferenciação glandular:

1) ausente; 2) presente. 
13. Porcentagem de diferenciação glandular:

1) ausente; 2) $1-10 \%$; 3) $11-20 \%$; 4) $21-30 \%$; 5) $31-40 \%$; 6) $41-50 \%$; 7) $51-$ $60 \%$; 8) 61-70\%; 9) 71-80\%; 10) 81-90\%; 11) $91-100 \%$.

14. Variante histológica:

1) ausente; 2) presente.

15. Tipo da variante histológica:

Especificar qual tipo:

16. Infiltração neoplásica linfovascular:

1) ausente; 2) presente.

17. Infiltração neoplásica perineural:

1) ausente; 2) presente.

18. Carcinoma urotelial in situ:

1) ausente; 2) presente.

19. Estádio patológico tumoral (AJCC/TNM 2009):

1) pT2a - infiltração da muscular própria superficial/metade interna;

2) pT2b - infiltração da muscular própria profunda/metade externa;

3) pT3a - infiltração do tecido perivesical microscópico;

4) pT3b - infiltração do tecido perivesical macroscópico (massa extravesical);

5) pT4a - infiltração do estroma prostático, vesículas seminais, útero, vagina;

6) pT4b - infiltração da parede pélvica, parede abdominal.

20. Metástase em linfonodo regional:

1) ausente; 2) presente.

21. Tamanho da maior metástase linfonodal:

1) células tumorais isoladas (até $0,2 \mathrm{~mm}$ );

2) micrometástase $(0,2 \mathrm{~mm}-2,0 \mathrm{~mm})$;

3) macrometástase (maior que $2,0 \mathrm{~mm}$ ).

22. Extensão neoplásica extranodal:

1) ausente; 2) presente. 


\section{Anexo B: Protocolo de estudo imuno-histoquímico}

- ( ) MMP-2 ( ) MMP-9 ( ) MMP-14

- Tumor primário: ( ) global ( ) epitélio neoplásico ( ) estroma

- Metástase linfonodal ( )

A) Avaliação da extensão/quantidade de positividade da reação:

0 (zero); 1 (1 - 10\%); 2 (11 - 20\%); 3 (21 - 30\%); 4 (31 - 40\%); 5 (41 - 50\%); 6 (51 - 60\%); 7 (61 - 70\%); 8 (71 - 80\%); 9 (81 - 90\%); 10 (91 - 100\%); 98 (perda de material no bloco de TMA); 99- não se aplica neste caso.

B) Avaliação da intensidade da reação:

0 (zero); 1 (fraca); 2 (forte/intensa); 98 (perda de material no bloco de TMA); 99- não se aplica neste caso.

C) Cálculo do escore da reação imuno-histoquímica:

Escore $=$ Positividade $(0-10) \times$ Intensidade $(0-2)$ 
Anexo C: Parte 1. Banco de dados - Variáveis clínico-patológicas da casuística (61 casos)

\begin{tabular}{|c|c|c|c|c|c|c|c|c|c|c|c|c|c|c|c|}
\hline $\begin{array}{l}\text { № } \\
\text { Caso }\end{array}$ & \begin{tabular}{|c|} 
№ Exame \\
AP \\
cistectomia
\end{tabular} & $\begin{array}{c}\text { № } \\
\text { RTUTB } \\
\text { prévia } \\
\end{array}$ & RGHC & Idade & Gênero & \begin{tabular}{|c|} 
Tamanho \\
tumor \\
primário $(\mathrm{cm})$
\end{tabular} & $\begin{array}{c}\text { Tumor } \\
\text { multifocal }\end{array}$ & $\begin{array}{c}\text { Grau } \\
\text { histológico }\end{array}$ & $\begin{array}{c}\text { Tipo/ } \\
\text { Configuração }\end{array}$ & $\begin{array}{c}\begin{array}{c}\text { Porcentagem } \\
\text { do tipo } \\
\text { papilífero (\%) }\end{array} \\
\end{array}$ & $\begin{array}{c}\text { Porcentagem } \\
\text { agrupada do tipo } \\
\text { papilífero (\%) } \\
\end{array}$ & $\begin{array}{l}\text { Padrão arquitetural de } \\
\text { invasão tumoral }\end{array}$ & $\begin{array}{c}\text { Grau de } \\
\text { atipia } \\
\text { nuclear } \\
\end{array}$ & $\begin{array}{l}\text { Componente } \\
\text { sarcomatoide }\end{array}$ & \begin{tabular}{|c|}
$\begin{array}{c}\text { Porcentagem } \\
\text { sarcomatoide } \\
(\%)\end{array}$ \\
\end{tabular} \\
\hline 1 & $06-3117$ & 0 & $13723049 \mathrm{~K}$ & 76 & M & 3 & não & alto & misto & $91-100$ & $>40$ & misto, infiltrativo-trabecular & intensa & ausente & 0 \\
\hline 2 & $06-4117$ & 0 & $13740746 \mathrm{~K}$ & 52 & $\mathrm{M}$ & 5 & não & alto & misto & $51-60$ & $>40$ & nodular & moderada & ausente & 0 \\
\hline 3 & $06-6382$ & 0 & $13678484 \mathrm{~F}$ & 51 & $M$ & 5 & não & alto & misto & $81-90$ & $>40$ & misto, nodular-trabecular & intensa & ausente & 0 \\
\hline 4 & 06-11942 & $06-10562$ & $13749922 \mathrm{~A}$ & 71 & $\mathrm{M}$ & 6 & $\operatorname{sim}$ & alto & misto & $81-90$ & $>40$ & misto, nodular-trabecular & moderada & ausente & 0 \\
\hline 5 & $06-13876$ & 0 & $13608824 \mathrm{~F}$ & 76 & $\mathrm{M}$ & 1,2 & $\operatorname{sim}$ & alto & misto & $31-40$ & $\leq 40$ & infiltrativo & intensa & ausente & 0 \\
\hline 6 & 06-20929 & 0 & $13753062 \mathrm{E}$ & 62 & M & 7,5 & $\operatorname{sim}$ & alto & não-papilifero & 0 & 0 & trabecular & intensa & ausente & 0 \\
\hline 7 & $07-616$ & 0 & 13756180D & 52 & $M$ & 3,5 & กล̃o & alto & não-papilifero & 0 & 0 & misto, infiltrativo-trabecular & intensa & presente & $21-30$ \\
\hline 8 & $07-11085$ & 0 & 13770454D & 62 & $M$ & 1,5 & não & alto & não-papilifero & 0 & 0 & infiltrativo & moderada & ausente & 0 \\
\hline 9 & $07-13565$ & $07-12170$ & $13750934 \mathrm{~B}$ & 67 & M & 1,5 & não & alto & misto & $81-90$ & $>40$ & misto, nodular-trabecular & intensa & ausente & 0 \\
\hline 10 & $07-22483$ & 0 & $44104693 \mathrm{H}$ & 79 & M & 7 & não & alto & não-papilifero & 0 & 0 & infiltrativo & intensa & presente & $91-100$ \\
\hline 11 & $07-25581$ & 0 & $13771913 \mathrm{C}$ & 83 & $\mathrm{M}$ & 3,5 & não & alto & não-papilifero & 0 & 0 & trabecular & moderada & ausente & 0 \\
\hline 12 & $07-26735$ & 0 & $13781337 \mathrm{~K}$ & 65 & $\mathrm{M}$ & 12 & não & alto & misto & $1-10$ & $\leq 40$ & misto, infiltrativo-trabecular & intensa & presente & $81-90$ \\
\hline 13 & $07-29727$ & 0 & $13783313 \mathrm{~K}$ & 58 & M & 3 & não & alto & misto & $21-30$ & $\leq 40$ & misto, infiltrativo-trabecular & intensa & ausente & 0 \\
\hline 14 & 07-30656 & 0 & $13776405 \mathrm{~J}$ & 77 & $\mathrm{M}$ & 3 & não & alto & não-papilifero & 0 & 0 & misto, infiltrativo-trabecular & moderada & ausente & 0 \\
\hline 15 & $07-31687$ & 0 & $13748665 \mathrm{C}$ & 63 & $\mathrm{M}$ & 2,5 & não & alto & não-papilifero & 0 & 0 & \begin{tabular}{|l|} 
misto, nodular-trabecular \\
\end{tabular} & moderada & ausente & 0 \\
\hline 16 & $07-34067$ & 0 & $13791573 \mathrm{~K}$ & 75 & M & 2,5 & não & alto & não-papilifero & 0 & 0 & infiltrativo & moderada & ausente & 0 \\
\hline 17 & $07-36199$ & 0 & 2881327D & 63 & $M$ & 2,5 & não & alto & não-papilifero & 0 & 0 & misto, infiltrativo-trabecular & moderada & ausente & 0 \\
\hline 18 & $07-39278$ & 0 & $13764092 \mathrm{G}$ & 65 & $M$ & $\mathrm{x}$ & não & alto & não-papilifero & 0 & 0 & misto, infiltrativo-trabecular & moderada & ausente & 0 \\
\hline 19 & $07-42112$ & 0 & 2927734 I & 71 & M & 3,4 & não & alto & não-papilifero & 0 & 0 & misto, infiltrativo-trabecular & intensa & presente & $6-10$ \\
\hline 20 & $07-43120$ & 0 & 13776911B & 60 & $\mathrm{~F}$ & 6 & não & alto & não-papilifero & 0 & 0 & infiltrativo & intensa & presente & $81-90$ \\
\hline 21 & $07-43274$ & 0 & $13786841 \mathrm{~B}$ & 72 & $\mathrm{M}$ & 6 & não & alto & misto & $21-30$ & $\leq 40$ & misto, infiltrativo-trabecular & intensa & ausente & 0 \\
\hline 22 & $07-45145$ & 0 & $13792749 \mathrm{~A}$ & 58 & M & 1,5 & $\operatorname{sim}$ & alto & misto & $21-30$ & $\leq 40$ & misto, infiltrativo-trabecular & intensa & ausente & 0 \\
\hline 23 & $08-2190$ & 0 & $13794107 \mathrm{G}$ & 74 & $\mathrm{M}$ & 7 & não & alto & misto & $81-90$ & $>40$ & misto, infiltrativo-trabecular & intensa & ausente & 0 \\
\hline 24 & $08-2909$ & 0 & $13806118 \mathrm{G}$ & 48 & M & 3 & não & alto & não-papilifero & 0 & 0 & infiltrativo & intensa & presente & $11-20$ \\
\hline 25 & $08-3167$ & 0 & 137760181 & 70 & $\mathrm{M}$ & 1 & não & alto & não-papilifero & 0 & 0 & infiltrativo & intensa & ausente & 0 \\
\hline 26 & $08-3322$ & 0 & $13799818 \mathrm{E}$ & 57 & M & 4,5 & $\operatorname{sim}$ & alto & não-papilifero & 0 & 0 & infiltrativo & intensa & ausente & 0 \\
\hline 27 & 08-3973 & 0 & $88502412 \mathrm{~B}$ & 65 & $\mathrm{M}$ & 2 & não & alto & não-papilifero & 0 & 0 & infiltrativo & intensa & ausente & 0 \\
\hline 28 & $08-13432$ & 0 & $13791093 \mathrm{C}$ & 60 & $\mathrm{M}$ & 7 & $\operatorname{sim}$ & alto & não-papilifero & 0 & 0 & misto, infiltrativo-trabecular & intensa & ausente & 0 \\
\hline 29 & \begin{tabular}{|l|}
$08-15012$ \\
\end{tabular} & 0 & $13813268 \mathrm{H}$ & 80 & $\mathrm{M}$ & 3,2 & não & alto & misto & $1-10$ & $\leq 40$ & misto, infiltrativo-trabecular & intensa & ausente & 0 \\
\hline 30 & $08-16864$ & 0 & $13802132 \mathrm{E}$ & 74 & M & 6 & não & alto & não-papilifero & 0 & 0 & misto, infiltrativo-trabecular & intensa & ausente & 0 \\
\hline 31 & 08-17394 & 0 & 138059111 & 73 & M & 2,1 & não & alto & não-papilifero & 0 & 0 & misto, infiltrativo-trabecular & intensa & ausente & 0 \\
\hline 32 & \begin{tabular}{|l|}
$08-20913$ \\
\end{tabular} & 0 & $13816739 \mathrm{C}$ & 66 & M & 5,5 & não & alto & misto & $31-40$ & $\leq 40$ & trabecular & intensa & ausente & 0 \\
\hline 33 & $08-21156$ & 0 & $88502747 \mid$ & 84 & $\mathrm{~F}$ & 7 & $\operatorname{sim}$ & alto & misto & $11-20$ & $\leq 40$ & trabecular & intensa & ausente & 0 \\
\hline 34 & $08-23404$ & 0 & $13600620 \mathrm{C}$ & 67 & M & 4 & não & alto & misto & $21-30$ & $\leq 40$ & misto, infiltrativo-trabecular & intensa & presente & $6-10$ \\
\hline
\end{tabular}


Conclusão Anexo C: Parte 1

\begin{tabular}{|c|c|c|c|c|c|c|c|c|c|c|c|c|c|c|c|}
\hline $\begin{array}{l}\text { № } \\
\text { Caso }\end{array}$ & \begin{tabular}{|c|}
$\begin{array}{c}\text { № Exame } \\
\text { AP } \\
\text { cistectomia }\end{array}$ \\
\end{tabular} & $\begin{array}{c}\text { № } \\
\text { RTUTB } \\
\text { prévia } \\
\end{array}$ & RGHC & Idade & Gênero & $\begin{array}{c}\text { Tamanho } \\
\text { tumor } \\
\text { primário }(\mathrm{cm}) \\
\end{array}$ & $\begin{array}{c}\text { Tumor } \\
\text { multifocal }\end{array}$ & $\begin{array}{c}\text { Grau } \\
\text { histológico }\end{array}$ & $\begin{array}{c}\text { Tipo/ } \\
\text { Configuração }\end{array}$ & $\begin{array}{c}\begin{array}{c}\text { Porcentagem } \\
\text { do tipo } \\
\text { papilifero (\%) }\end{array} \\
\end{array}$ & $\begin{array}{c}\text { Porcentagem } \\
\text { agrupada do tipo } \\
\text { papilifero }(\%)\end{array}$ & $\begin{array}{l}\text { Padrão arquitetural de } \\
\text { invasão tumoral }\end{array}$ & \begin{tabular}{|c|} 
Grau de \\
atipia \\
nuclear \\
\end{tabular} & $\begin{array}{l}\text { Componente } \\
\text { sarcomatoide }\end{array}$ & \begin{tabular}{|c|}
$\begin{array}{c}\text { Porcentagem } \\
\text { sarcomatoide } \\
(\%)\end{array}$ \\
\end{tabular} \\
\hline 35 & $08-29037$ & 0 & 13819170I & 59 & $\mathrm{M}$ & 5 & não & alto & misto & $21-30$ & $\leq 40$ & misto, infiltrativo-trabecular & intensa & ausente & 0 \\
\hline 36 & $08-33337$ & 0 & $13826710 \mathrm{~A}$ & 71 & M & 4 & $\operatorname{sim}$ & alto & não-papilífero & 0 & 0 & misto, infiltrativo-trabecular & intensa & ausente & 0 \\
\hline 37 & $08-38552$ & 0 & 13820229F & 46 & $\mathrm{~F}$ & 5,5 & não & alto & misto & $61-70$ & $>40$ & nodular & moderada & ausente & 0 \\
\hline 38 & $08-43238$ & 0 & 2934387E & 78 & M & 3 & $\operatorname{sim}$ & alto & misto & $1-10$ & $\leq 40$ & trabecular & intensa & ausente & 0 \\
\hline 39 & $08-44312$ & 0 & 13788897D & 54 & $\mathrm{~F}$ & 6 & não & alto & misto & $11-20$ & $\leq 40$ & misto, nodular-trabecular & moderada & ausente & 0 \\
\hline 40 & $09-70$ & 0 & 4017425J & 59 & $\mathrm{~F}$ & 2,5 & não & alto & não-papilifero & 0 & 0 & misto, infiltrativo-trabecular & moderada & ausente & 0 \\
\hline 41 & 09-1537 & 0 & $13814570 \mathrm{G}$ & 83 & $\mathrm{M}$ & 6 & não & alto & misto & $31-40$ & $\leq 40$ & misto, infiltrativo-trabecular & intensa & ausente & 0 \\
\hline 42 & $09-2641$ & 0 & $5027942 \mathrm{~F}$ & 70 & $\mathrm{~F}$ & 2,2 & $\operatorname{sim}$ & alto & misto & $1-10$ & $\leq 40$ & infiltrativo & moderada & ausente & 0 \\
\hline 43 & $09-2787$ & $08-42026$ & $55378139 \mathrm{~K}$ & 79 & $\mathrm{M}$ & 4,5 & não & alto & misto & $1-10$ & $\leq 40$ & misto, infiltrativo-trabecular & intensa & ausente & 0 \\
\hline 44 & $09-5522$ & 0 & $13842508 \mathrm{~A}$ & 67 & $\mathrm{~F}$ & 4 & não & alto & misto & $1-10$ & $\leq 40$ & misto, infiltrativo-trabecular & intensa & ausente & 0 \\
\hline 45 & $09-8981$ & 0 & $13863895 \mathrm{C}$ & 54 & M & 3 & não & alto & não-papiliffero & 0 & 0 & misto, infiltrativo-trabecular & intensa & ausente & 0 \\
\hline 46 & $09-11028$ & 0 & $13861473 \mathrm{D}$ & 59 & $M$ & 3,5 & não & alto & não-papiliffero & 0 & 0 & misto, infiltrativo-trabecular & intensa & ausente & 0 \\
\hline 47 & $09-14462$ & 0 & 13830572B & 71 & $M$ & 6,5 & não & alto & misto & $81-90$ & $>40$ & misto, infiltrativo-trabecular & moderada & ausente & 0 \\
\hline 48 & $09-14474$ & 0 & $13844017 \mathrm{I}$ & 73 & $\mathrm{M}$ & 9 & não & alto & misto & $11-20$ & $\leq 40$ & misto, infiltrativo-trabecular & intensa & ausente & 0 \\
\hline 49 & 09-19244 & 0 & 7027949E & 76 & $\mathrm{M}$ & 5 & não & alto & não-papilífero & 0 & 0 & misto, infiltrativo-trabecular & intensa & ausente & 0 \\
\hline 50 & $09-31030$ & 0 & 138855901 & 68 & $\mathrm{~F}$ & 3 & não & alto & não-papilífero & 0 & 0 & misto, infiltrativo-trabecular & intensa & ausente & 0 \\
\hline 51 & (28) 09-1669 & 0 & 600010931 & 40 & $\mathrm{M}$ & 1,5 & não & alto & não-papilifero & 0 & 0 & trabecular & intensa & ausente & 0 \\
\hline 52 & (28) 09-2614 & 0 & 138797691 & 49 & $\mathrm{M}$ & 1,8 & não & alto & não-papilifero & 0 & 0 & infiltrativo & intensa & ausente & 0 \\
\hline 53 & (28) 09-3439 & 0 & $7041089 C$ & 50 & $\mathrm{M}$ & 5,5 & não & alto & papilifero & $91-100$ & $>40$ & trabecular & moderada & ausente & 0 \\
\hline 54 & (28) 09-3786 & 0 & $13855807 \mathrm{~B}$ & 78 & M & 4 & não & alto & não-papilífero & 0 & 0 & misto, infiltrativo-trabecular & intensa & ausente & 0 \\
\hline 55 & (28) 09-4090 & 0 & $13890048 \mathrm{~K}$ & 71 & M & 3 & não & alto & não-papilífero & 0 & 0 & misto, infiltrativo-trabecular & intensa & presente & $1-5$ \\
\hline 56 & $656634-0$ & 0 & $13483553 \mathrm{~A}$ & 75 & M & 5 & não & alto & misto & $81-90$ & $>40$ & nodular & moderada & ausente & 0 \\
\hline 57 & $461071-7$ & 0 & $3347885 \mathrm{~K}$ & 60 & M & 9 & não & alto & não-papilífero & 0 & 0 & infiltrativo & intensa & presente & $91-100$ \\
\hline 58 & $673167-8$ & 0 & $13488922 \mathrm{C}$ & 72 & $\mathrm{~F}$ & 3,5 & não & alto & não-papilífero & 0 & 0 & misto, infiltrativo-trabecular & intensa & ausente & 0 \\
\hline 59 & $685272-6$ & 0 & 55385607 & 67 & $\mathrm{~F}$ & 6 & não & alto & não-papilifero & 0 & 0 & infiltrativo & intensa & ausente & 0 \\
\hline 60 & $691247-8$ & 0 & $13694007 \mathrm{G}$ & 45 & $\mathrm{M}$ & 1,7 & não & alto & não-papilifero & 0 & 0 & misto, infiltrativo-trabecular & intensa & ausente & 0 \\
\hline 61 & $702478-9$ & 0 & $13712123 \mathrm{H}$ & 40 & M & 5,5 & não & alto & não-papilífero & 0 & 0 & misto, infiltrativo-trabecular & intensa & ausente & 0 \\
\hline
\end{tabular}

AP: anatomopatológico; RTUTB: ressecção transuretral de tumor de bexiga; M: masculino; F: feminino; $x$ : dado não disponível. 
Anexo C continuação: Parte 2. Banco de dados - Informações clínicas e variáveis anatomopatológicas da casuística (61 casos)

\begin{tabular}{|c|c|c|c|c|c|c|c|c|c|c|c|c|c|c|c|}
\hline $\begin{array}{c}\text { № } \\
\text { Caso }\end{array}$ & \begin{tabular}{|} 
Diferenciação \\
escamosa
\end{tabular} & $\begin{array}{c}\text { Porcentagem } \\
\text { escamosa } \\
\text { (\%) }\end{array}$ & $\begin{array}{c}\text { Diferenciação } \\
\text { glandular }\end{array}$ & $\begin{array}{l}\text { Porcentagem } \\
\text { glandular }(\%)\end{array}$ & $\begin{array}{c}\text { Variante } \\
\text { histológica }\end{array}$ & $\begin{array}{c}\text { Tipo da } \\
\text { variante } \\
\text { histológica }\end{array}$ & $\begin{array}{c}\text { Invasão } \\
\text { linfovascular }\end{array}$ & $\left|\begin{array}{c}\text { Invasão } \\
\text { perineural }\end{array}\right|$ & $\begin{array}{c}\text { Carcinoma } \\
\text { in situ }\end{array}$ & \begin{tabular}{|c|} 
Estádio \\
tumor \\
AJCC/TNM \\
2009
\end{tabular} & \begin{tabular}{|c} 
Estádio \\
tumoral \\
agrupado \\
pT2 versus \\
pT3+pT4 \\
\end{tabular} & \begin{tabular}{|c} 
Estádio \\
tumoral \\
agrupado \\
pT2+pT3 \\
versus pT4 \\
\end{tabular} & $\begin{array}{l}\text { Metástase } \\
\text { linfonodo } \\
\text { regional }\end{array}$ & $\begin{array}{c}\text { Tamanho maior } \\
\text { metástase } \\
\text { linfonodal }\end{array}$ & $\begin{array}{l}\text { Extensão } \\
\text { extranodal }\end{array}$ \\
\hline 1 & ausente & 0 & ausente & 0 & ausente & ausente & ausente & ausente & presente & pт3a & pT3 + pT4 & pT2 + pT3 & ausente & não se aplica & não se aplica \\
\hline 2 & ausente & 0 & presente & $1-10$ & ausente & ausente & presente & ausente & presente & pT4a & pT3 + pT4 & pT4 & presente & macrometástase & presente \\
\hline 3 & ausente & 0 & ausente & 0 & ausente & ausente & presente & ausente & presente & рТЗа & pT3+pT4 & pT2 + pT3 & ausente & não se aplica & não se aplica \\
\hline 4 & ausente & 0 & presente & $1-10$ & ausente & ausente & presente & presente & ausente & pT3b & pT3 + pT4 & pT2 + pT3 & ausente & não se aplica & não se aplica \\
\hline 5 & ausente & 0 & ausente & 0 & ausente & ausente & ausente & ausente & presente & pT4a & pT3 + pT4 & pT4 & ausente & não se aplica & não se aplica \\
\hline 6 & ausente & 0 & ausente & 0 & ausente & ausente & presente & presente & presente & pT2b & pT2 & pT2 + pT3 & presente & macrometástase & ausente \\
\hline 7 & ausente & 0 & ausente & 0 & ausente & ausente & presente & presente & presente & pT3b & pT3 + pT4 & pT2 + pT3 & presente & macrometástase & presente \\
\hline 8 & ausente & 0 & ausente & 0 & presente & ninhos & presente & presente & ausente & pT3a & pT3 + pT4 & pT2 + pT3 & presente & macrometástase & presente \\
\hline 9 & ausente & 0 & ausente & 0 & ausente & ausente & presente & ausente & presente & pT2b & pT2 & pT2 + pT3 & ausente & não se aplica & não se aplica \\
\hline 10 & ausente & 0 & ausente & 0 & ausente & ausente & presente & presente & ausente & pT3a & pT3 + pT4 & pT2 + pT3 & presente & macrometástase & presente \\
\hline 11 & ausente & 0 & ausente & 0 & ausente & ausente & presente & presente & ausente & pT3b & pT3 + pT4 & pT2 + pT3 & ausente & não se aplica & não se aplica \\
\hline 12 & presente & $1-10$ & ausente & 0 & ausente & ausente & presente & presente & presente & рТЗа & pT3+ pT4 & pT2 + pT3 & presente & macrometástase & presente \\
\hline 13 & presente & $1-10$ & ausente & 0 & ausente & ausente & presente & ausente & presente & pT2b & pT2 & pT2 + pT3 & presente & macrometástase & ausente \\
\hline 14 & ausente & 0 & ausente & 0 & presente & células claras & ausente & presente & presente & pT3a & pT3+ pT4 & pT2 + pT3 & ausente & não se aplica & não se aplica \\
\hline 15 & ausente & 0 & ausente & 0 & ausente & ausente & presente & presente & ausente & pT3b & pT3 + pT4 & pT2 + pT3 & ausente & não se aplica & não se aplica \\
\hline 16 & ausente & 0 & ausente & 0 & ausente & ausente & presente & presente & ausente & pT3a & pT3 + pT4 & pT2 + pT3 & ausente & não se aplica & não se aplica \\
\hline 17 & ausente & 0 & ausente & 0 & presente & ninhos & presente & presente & presente & рт3а & pT3 + pT4 & pT2 + pT3 & presente & macrometástase & presente \\
\hline 18 & ausente & 0 & ausente & 0 & ausente & ausente & presente & presente & ausente & pT4a & pT3+ pT4 & pT4 & presente & macrometástase & presente \\
\hline 19 & presente & $1-10$ & ausente & 0 & ausente & ausente & presente & presente & ausente & pT4a & pT3 + pT4 & pT4 & $\begin{array}{c}\text { sem } \\
\text { linfadenectomia }\end{array}$ & $\begin{array}{c}\text { sem } \\
\text { linfadenectomia }\end{array}$ & $\begin{array}{c}\text { sem } \\
\text { linfadenectomia }\end{array}$ \\
\hline 20 & ausente & 0 & ausente & 0 & presente & $\begin{array}{c}\text { células } \\
\text { pequenas }\end{array}$ & presente & presente & ausente & рТ $3 \mathrm{~b}$ & pT3 + pT4 & pT2 + pT3 & presente & macrometástase & presente \\
\hline 21 & ausente & 0 & ausente & 0 & ausente & ausente & presente & presente & ausente & pT4a & pT3 + pT4 & pT4 & $\begin{array}{c}\text { sem } \\
\text { linfadenectomia }\end{array}$ & $\begin{array}{c}\text { sem } \\
\text { linfadenectomia }\end{array}$ & $\begin{array}{c}\text { sem } \\
\text { linfadenectomia }\end{array}$ \\
\hline 22 & ausente & 0 & ausente & 0 & ausente & ausente & presente & ausente & ausente & pT4a & pT3+pT4 & pT4 & presente & macrometástase & ausente \\
\hline 23 & ausente & 0 & ausente & 0 & ausente & ausente & presente & ausente & presente & pT4a & pT3 + pT4 & pT4 & presente & micrometástase & ausente \\
\hline 24 & presente & $21-30$ & ausente & 0 & presente & micropapilifera & presente & presente & presente & pT4a & pT3 + pT4 & pT4 & presente & macrometástase & presente \\
\hline 25 & ausente & 0 & ausente & 0 & presente & $\begin{array}{l}\text { linfoepitelioma- } \\
\text { símile }\end{array}$ & ausente & ausente & presente & рТЗа & pT3 + pT4 & $\mathrm{pT} 2+\mathrm{pT} 3$ & $\begin{array}{c}\text { sem } \\
\text { linfadenectomia }\end{array}$ & $\begin{array}{c}\text { sem } \\
\text { linfadenectomia }\end{array}$ & $\begin{array}{c}\text { sem } \\
\text { linfadenectomia }\end{array}$ \\
\hline 26 & ausente & 0 & ausente & 0 & ausente & ausente & presente & ausente & ausente & pT3a & pT3 + pT4 & pT2+ pT3 & presente & macrometástase & ausente \\
\hline 27 & ausente & 0 & ausente & 0 & ausente & ausente & ausente & presente & ausente & рт3а & pT3 + pT4 & pT2 + pT3 & ausente & não se aplica & não se aplica \\
\hline 28 & presente & $1-10$ & ausente & 0 & presente & células claras & presente & presente & ausente & pT3b & pT3 + pT4 & pT2 + pT3 & presente & macrometástase & ausente \\
\hline 29 & ausente & 0 & ausente & 0 & presente & ninhos & presente & ausente & presente & pT2b & pT2 & pT2 + pT3 & ausente & não se aplica & não se aplica \\
\hline
\end{tabular}


Conclusão Anexo C: Parte 2

\begin{tabular}{|c|c|c|c|c|c|c|c|c|c|c|c|c|c|c|c|}
\hline $\begin{array}{c}\text { № } \\
\text { Caso }\end{array}$ & \begin{tabular}{|} 
Diferenciação \\
escamosa
\end{tabular} & $\begin{array}{c}\text { Porcentagem } \\
\text { escamosa } \\
(\%)\end{array}$ & $\begin{array}{c}\text { Diferenciação } \\
\text { glandular }\end{array}$ & $\begin{array}{l}\text { Porcentagem } \\
\text { glandular (\%) }\end{array}$ & $\begin{array}{c}\text { Variante } \\
\text { histológica }\end{array}$ & $\begin{array}{c}\text { Tipo da } \\
\text { variante } \\
\text { histológica }\end{array}$ & $\begin{array}{c}\text { Invasão } \\
\text { linfovascular }\end{array}$ & $\mid \begin{array}{c}\text { Invasão } \\
\text { perineural }\end{array}$ & $\begin{array}{c}\text { Carcinoma } \\
\text { in situ }\end{array}$ & $\begin{array}{c}\text { Estádio } \\
\text { tumor } \\
\text { AJCC/TNM } \\
2009\end{array}$ & $\begin{array}{c}\text { Estádio } \\
\text { tumoral } \\
\text { agrupado } \\
\text { pT2 versus } \\
\text { pT3+pT4 }\end{array}$ & \begin{tabular}{|c} 
Estádio \\
tumoral \\
agrupado \\
pT2+pT3 \\
versus pT4
\end{tabular} & $\begin{array}{c}\text { Metástase } \\
\text { linfonodo } \\
\text { regional }\end{array}$ & $\begin{array}{c}\text { Tamanho maior } \\
\text { metástase } \\
\text { linfonodal }\end{array}$ & $\begin{array}{l}\text { Extensão } \\
\text { extranodal }\end{array}$ \\
\hline 30 & ausente & 0 & ausente & 0 & ausente & ausente & presente & presente & presente & pT4a & pT3 + pT4 & pT4 & presente & macrometástase & ausente \\
\hline 31 & ausente & 0 & ausente & 0 & ausente & ausente & ausente & presente & ausente & pT3b & pT3 + pT4 & pT2 + pT3 & ausente & não se aplica & não se aplica \\
\hline 32 & ausente & 0 & presente & $11-20$ & ausente & ausente & ausente & ausente & ausente & pT2b & pT2 & pT2 + pT3 & ausente & não se aplica & não se aplica \\
\hline 33 & ausente & 0 & ausente & 0 & ausente & ausente & presente & ausente & presente & pT3b & pT3 + pT4 & pT2 + pT3 & presente & macrometástase & ausente \\
\hline 34 & ausente & 0 & ausente & 0 & ausente & ausente & presente & presente & ausente & pT3b & pT3 + pT4 & pT2 + pT3 & ausente & não se aplica & não se aplica \\
\hline 35 & ausente & 0 & ausente & 0 & ausente & ausente & presente & presente & presente & pT3b & pT3 + pT4 & pT2 + pT3 & presente & macrometástase & ausente \\
\hline 36 & ausente & 0 & ausente & 0 & ausente & ausente & presente & presente & ausente & pT4a & pT3 + pT4 & pT4 & presente & macrometástase & presente \\
\hline 37 & ausente & 0 & ausente & 0 & ausente & ausente & ausente & ausente & ausente & pT2b & pT2 & pT2 + pT3 & ausente & não se aplica & não se aplica \\
\hline 38 & ausente & 0 & ausente & 0 & presente & micropapilifera & presente & presente & presente & pT4a & pT3 + pT4 & pT4 & presente & macrometástase & ausente \\
\hline 39 & ausente & 0 & ausente & 0 & ausente & ausente & presente & ausente & ausente & pT4a & pT3 + pT4 & pT4 & presente & macrometástase & ausente \\
\hline 40 & ausente & 0 & presente & $1-10$ & ausente & ausente & presente & presente & ausente & pT2b & pT2 & pT2 + pT3 & presente & macrometástase & ausente \\
\hline 41 & presente & $1-10$ & ausente & 0 & ausente & ausente & presente & presente & ausente & pT3b & pT3 + pT4 & pT2 + pT3 & presente & macrometástase & presente \\
\hline 42 & presente & $1-10$ & ausente & 0 & presente & ninhos & presente & presente & presente & pT3b & pT3 + pT4 & pT2 + pT3 & presente & macrometástase & ausente \\
\hline 43 & ausente & 0 & ausente & 0 & ausente & ausente & presente & presente & presente & pT3b & pT3 + pT4 & pT2 + pT3 & $\begin{array}{c}\text { sem } \\
\text { linfadenectomia }\end{array}$ & $\begin{array}{c}\text { sem } \\
\text { linfadenectomia }\end{array}$ & $\begin{array}{c}\text { sem } \\
\text { linfadenectomia }\end{array}$ \\
\hline 44 & ausente & 0 & ausente & 0 & ausente & ausente & presente & presente & ausente & pT3b & pT3 + pT4 & pT2 + pT3 & presente & macrometástase & ausente \\
\hline 45 & presente & $11-20$ & ausente & 0 & ausente & ausente & ausente & presente & presente & pT3b & pT3 + pT4 & pT2 + pT3 & ausente & não se aplica & não se aplica \\
\hline 46 & ausente & 0 & ausente & 0 & ausente & ausente & presente & presente & ausente & рТ3a & pT3 + pT4 & pT2 + pT3 & presente & macrometástase & ausente \\
\hline 47 & ausente & 0 & ausente & 0 & ausente & ausente & presente & ausente & ausente & рТ3a & pT3 + pT4 & pT2 + pT3 & presente & macrometástase & ausente \\
\hline 48 & ausente & 0 & ausente & 0 & presente & células claras & presente & presente & ausente & рТ3a & pT3 + pT4 & pT2 + pT3 & ausente & não se aplica & não se aplica \\
\hline 49 & ausente & 0 & ausente & 0 & ausente & ausente & presente & presente & ausente & pT3a & pT3 + pT4 & pT2 + pT3 & ausente & não se aplica & não se aplica \\
\hline 50 & ausente & 0 & ausente & 0 & ausente & ausente & presente & presente & presente & pT3a & pT3 + pT4 & $\mathrm{pT} 2+\mathrm{pT} 3$ & ausente & não se aplica & não se aplica \\
\hline 51 & ausente & 0 & ausente & 0 & ausente & ausente & presente & presente & ausente & pT3a & pT3 + pT4 & $\mathrm{pT} 2+\mathrm{pT} 3$ & presente & macrometástase & ausente \\
\hline 52 & ausente & 0 & ausente & 0 & presente & micropapilifera & presente & presente & presente & рT3a & pT3 + pT4 & pT2 + pT3 & presente & macrometástase & presente \\
\hline 53 & ausente & 0 & ausente & 0 & presente & $\begin{array}{c}\text { padrão } \\
\text { invertido }\end{array}$ & ausente & ausente & ausente & pT2b & pT2 & pT2 + pT3 & ausente & não se aplica & não se aplica \\
\hline 54 & ausente & 0 & ausente & 0 & ausente & ausente & ausente & ausente & presente & pT4a & pT3 + pT4 & pT4 & ausente & não se aplica & não se aplica \\
\hline 55 & ausente & 0 & presente & $11-20$ & ausente & ausente & presente & ausente & presente & pT2a & pT2 & pT2 + pT3 & presente & macrometástase & ausente \\
\hline 56 & ausente & 0 & ausente & 0 & ausente & ausente & ausente & ausente & ausente & pT3a & pT3 + pT4 & pT2 + pT3 & ausente & não se aplica & não se aplica \\
\hline 57 & ausente & 0 & ausente & 0 & ausente & ausente & presente & ausente & ausente & pT3b & pT3 + pT4 & pT2 + pT3 & presente & micrometástase & ausente \\
\hline 58 & ausente & 0 & presente & $51-60$ & ausente & ausente & ausente & ausente & presente & pT2b & pT2 & pT2 + pT3 & ausente & não se aplica & não se aplica \\
\hline 59 & ausente & 0 & ausente & 0 & ausente & ausente & presente & presente & presente & pT4a & pT3 + pT4 & pT4 & presente & macrometástase & presente \\
\hline 60 & ausente & 0 & ausente & 0 & ausente & ausente & presente & ausente & ausente & pT2b & pT2 & pT2 + pT3 & presente & macrometástase & ausente \\
\hline 61 & ausente & 0 & ausente & 0 & ausente & ausente & presente & presente & ausente & pT2b & pT2 & pT2 + pT3 & presente & macrometástase & presente \\
\hline
\end{tabular}


Anexo D: Estudo imuno-histoquímico de MMP-2 - distribuição da positividade, intensidade e escore no tumor primário e na metástase linfonodal

\begin{tabular}{|c|c|c|c|c|c|c|c|c|c|c|c|c|c|}
\hline \multirow{3}{*}{$\begin{array}{l}\text { № } \\
\text { Caso }\end{array}$} & \multirow{3}{*}{$\begin{array}{c}\text { № AP } \\
\text { cistectomia }\end{array}$} & \multicolumn{12}{|c|}{ Imunoexpressão de MMP-2 } \\
\hline & & \multicolumn{9}{|c|}{$\begin{array}{l}\text { Tumor primário } \\
\text { Epitélio neoplásico }\end{array}$} & \multicolumn{3}{|c|}{$\begin{array}{l}\text { Metástase } \\
\text { linfonodal }\end{array}$} \\
\hline & & POS & INT & Escore & POS & INT & Escore & POS & INT & Escore & POS & INT & Escore \\
\hline 1 & $06-3117$ & 1 & 1 & 1 & 1 & 1 & 1 & 1 & 1 & 1 & 99 & 99 & 99 \\
\hline 2 & $06-4117$ & 0 & 0 & 0 & 0 & 0 & 0 & 0 & 0 & 0 & 1 & 1 & 1 \\
\hline 3 & $06-6382$ & 3 & 1 & 3 & 3 & 1 & 3 & 1 & 1 & 1 & 99 & 99 & 99 \\
\hline 4 & 06-11942 & 0 & 0 & 0 & 0 & 0 & 0 & 0 & 0 & 0 & 99 & 99 & 99 \\
\hline 5 & 06-13876 & 1 & 1 & 1 & 1 & 1 & 1 & 0 & 0 & 0 & 99 & 99 & 99 \\
\hline 6 & 06-20929 & 0 & 0 & 0 & 0 & 0 & 0 & 0 & 0 & 0 & 0 & 0 & 0 \\
\hline 7 & $07-616$ & 0 & 0 & 0 & 0 & 0 & 0 & 0 & 0 & 0 & 0 & 0 & 0 \\
\hline 8 & 07-11085 & 0 & 0 & 0 & 0 & 0 & 0 & 0 & 0 & 0 & 98 & 98 & 98 \\
\hline 9 & 07-13565 & 2 & 1 & 2 & 2 & 1 & 2 & 0 & 0 & 0 & 99 & 99 & 99 \\
\hline 10 & $07-22483$ & 1 & 1 & 1 & 1 & 1 & 1 & 0 & 0 & 0 & 3 & 2 & 6 \\
\hline 11 & $07-25581$ & 1 & 2 & 2 & 0 & 0 & 0 & 1 & 2 & 2 & 99 & 99 & 99 \\
\hline 12 & $07-26735$ & 1 & 1 & 1 & 1 & 1 & 1 & 1 & 1 & 1 & 1 & 1 & 1 \\
\hline 13 & $07-29727$ & 0 & 0 & 0 & 0 & 0 & 0 & 0 & 0 & 0 & 4 & 1 & 4 \\
\hline 14 & 07-30656 & 0 & 0 & 0 & 0 & 0 & 0 & 0 & 0 & 0 & 99 & 99 & 99 \\
\hline 15 & 07-31687 & 3 & 1 & 3 & 3 & 1 & 3 & 0 & 0 & 0 & 99 & 99 & 99 \\
\hline 16 & $07-34067$ & 1 & 2 & 2 & 1 & 1 & 1 & 1 & 2 & 2 & 99 & 99 & 99 \\
\hline 17 & 07-36199 & 3 & 2 & 6 & 3 & 2 & 6 & 1 & 1 & 1 & 5 & 1 & 5 \\
\hline 18 & 07-39278 & 1 & 1 & 1 & 1 & 1 & 1 & 1 & 1 & 1 & 4 & 2 & 8 \\
\hline 19 & $07-42112$ & 3 & 2 & 6 & 3 & 2 & 6 & 3 & 1 & 3 & 99 & 99 & 99 \\
\hline 20 & $07-43120$ & 1 & 1 & 1 & 1 & 1 & 1 & 1 & 1 & 1 & 2 & 1 & 2 \\
\hline 21 & $07-43274$ & 2 & 1 & 2 & 2 & 1 & 2 & 1 & 1 & 1 & 99 & 99 & 99 \\
\hline 22 & $07-45145$ & 0 & 0 & 0 & 0 & 0 & 0 & 0 & 0 & 0 & 1 & 1 & 1 \\
\hline 23 & $08-2190$ & 0 & 0 & 0 & 0 & 0 & 0 & 0 & 0 & 0 & 0 & 0 & 0 \\
\hline 24 & 08-2909 & 1 & 1 & 1 & 1 & 1 & 1 & 0 & 0 & 0 & 1 & 1 & 1 \\
\hline 25 & $08-3167$ & 1 & 1 & 1 & 1 & 1 & 1 & 0 & 0 & 0 & 99 & 99 & 99 \\
\hline 26 & $08-3322$ & 0 & 0 & 0 & 0 & 0 & 0 & 0 & 0 & 0 & 8 & 1 & 8 \\
\hline 27 & $08-3973$ & 0 & 0 & 0 & 0 & 0 & 0 & 0 & 0 & 0 & 99 & 99 & 99 \\
\hline 28 & $08-13432$ & 2 & 1 & 2 & 2 & 1 & 2 & 1 & 1 & 1 & 0 & 0 & 0 \\
\hline 29 & 08-15012 & 1 & 1 & 1 & 0 & 0 & 0 & 1 & 1 & 1 & 99 & 99 & 99 \\
\hline 30 & $08-16864$ & 1 & 1 & 1 & 1 & 1 & 1 & 0 & 0 & 0 & 0 & 0 & 0 \\
\hline 31 & 08-17394 & 1 & 1 & 1 & 0 & 0 & 0 & 1 & 1 & 1 & 99 & 99 & 99 \\
\hline 32 & 08-20913 & 0 & 0 & 0 & 0 & 0 & 0 & 0 & 0 & 0 & 99 & 99 & 99 \\
\hline
\end{tabular}

Continua... 
Conclusão Anexo D

\begin{tabular}{|c|c|c|c|c|c|c|c|c|c|c|c|c|c|}
\hline \multirow{3}{*}{$\begin{array}{c}\text { № } \\
\text { Caso }\end{array}$} & \multirow{3}{*}{$\begin{array}{c}\text { № AP } \\
\text { cistectomia }\end{array}$} & \multicolumn{12}{|c|}{ Imunoexpressão de MMP-2 } \\
\hline & & \multicolumn{9}{|c|}{ Tumor primário } & \multicolumn{3}{|c|}{$\begin{array}{l}\text { Metástase } \\
\text { linfonodal }\end{array}$} \\
\hline & & POS & INT & Escore & POS & INT & Escore & POS & INT & Escore & POS & INT & Escore \\
\hline 33 & $08-21156$ & 1 & 1 & 1 & 1 & 1 & 1 & 0 & 0 & 0 & 1 & 1 & 1 \\
\hline 34 & 08-23404 & 0 & 0 & 0 & 0 & 0 & 0 & 0 & 0 & 0 & 99 & 99 & 99 \\
\hline 35 & 08-29037 & 0 & 0 & 0 & 0 & 0 & 0 & 0 & 0 & 0 & 0 & 0 & 0 \\
\hline 36 & 08-33337 & 0 & 0 & 0 & 0 & 0 & 0 & 0 & 0 & 0 & 0 & 0 & 0 \\
\hline 37 & 08-38552 & 0 & 0 & 0 & 0 & 0 & 0 & 0 & 0 & 0 & 99 & 99 & 99 \\
\hline 38 & $08-43238$ & 1 & 1 & 1 & 1 & 1 & 1 & 1 & 1 & 1 & 2 & 1 & 2 \\
\hline 39 & $08-44312$ & 0 & 0 & 0 & 0 & 0 & 0 & 0 & 0 & 0 & 98 & 98 & 98 \\
\hline 40 & $09-70$ & 1 & 1 & 1 & 1 & 1 & 1 & 0 & 0 & 0 & 0 & 0 & 0 \\
\hline 41 & $09-1537$ & 1 & 1 & 1 & 0 & 0 & 0 & 1 & 1 & 1 & 1 & 1 & 1 \\
\hline 42 & $09-2641$ & 2 & 1 & 2 & 2 & 1 & 2 & 0 & 0 & 0 & 1 & 1 & 1 \\
\hline 43 & $09-2787$ & 0 & 0 & 0 & 0 & 0 & 0 & 0 & 0 & 0 & 99 & 99 & 99 \\
\hline 44 & $09-5522$ & 2 & 1 & 2 & 2 & 1 & 2 & 1 & 1 & 1 & 1 & 1 & 1 \\
\hline 45 & 09-8981 & 0 & 0 & 0 & 0 & 0 & 0 & 0 & 0 & 0 & 99 & 99 & 99 \\
\hline 46 & $09-11028$ & 0 & 0 & 0 & 0 & 0 & 0 & 0 & 0 & 0 & 0 & 0 & 0 \\
\hline 47 & $09-14462$ & 1 & 1 & 1 & 1 & 1 & 1 & 0 & 0 & 0 & 1 & 1 & 1 \\
\hline 48 & $09-14474$ & 1 & 1 & 1 & 0 & 0 & 0 & 1 & 1 & 1 & 99 & 99 & 99 \\
\hline 49 & 09-19244 & 0 & 0 & 0 & 0 & 0 & 0 & 0 & 0 & 0 & 99 & 99 & 99 \\
\hline 50 & $09-31030$ & 1 & 2 & 2 & 1 & 2 & 2 & 0 & 0 & 0 & 99 & 99 & 99 \\
\hline 51 & (28) 09-1669 & 2 & 2 & 4 & 2 & 2 & 4 & 1 & 1 & 1 & 2 & 2 & 4 \\
\hline 52 & (28) 09-2614 & 2 & 1 & 2 & 2 & 1 & 2 & 1 & 1 & 1 & 0 & 0 & 0 \\
\hline 53 & (28) 09-3439 & 0 & 0 & 0 & 0 & 0 & 0 & 0 & 0 & 0 & 99 & 99 & 99 \\
\hline 54 & (28) 09-3786 & 1 & 2 & 2 & 1 & 2 & 2 & 1 & 1 & 1 & 99 & 99 & 99 \\
\hline 55 & (28) 09-4090 & 2 & 1 & 2 & 2 & 1 & 2 & 1 & 1 & 1 & 2 & 1 & 2 \\
\hline 56 & $656634-0$ & 3 & 1 & 3 & 3 & 1 & 3 & 0 & 0 & 0 & 99 & 99 & 99 \\
\hline 57 & $461071-7$ & 1 & 1 & 1 & 1 & 1 & 1 & 1 & 1 & 1 & 0 & 0 & 0 \\
\hline 58 & 673167-8 & 0 & 0 & 0 & 0 & 0 & 0 & 0 & 0 & 0 & 99 & 99 & 99 \\
\hline 59 & $685272-6$ & 0 & 0 & 0 & 0 & 0 & 0 & 0 & 0 & 0 & 1 & 1 & 1 \\
\hline 60 & $691247-8$ & 0 & 0 & 0 & 0 & 0 & 0 & 0 & 0 & 0 & 0 & 0 & 0 \\
\hline 61 & $702478-9$ & 1 & 2 & 2 & 1 & 2 & 2 & 0 & 0 & 0 & 3 & 1 & 3 \\
\hline
\end{tabular}

MMP-2: Metaloproteinase de matriz 2; POS: Positividade da reação imuno-histoquímica; INT: intensidade da reação imuno-histoquímica; 98: perda de material/tecido não representativo nos cortes a partir do tissue microarray, 99: não avaliável neste caso (sem linfadenectomia/metástase ausente). 
Anexo E: Estudo imuno-histoquímico de MMP-9 - distribuição da positividade, intensidade e escore no tumor primário e na metástase linfonodal

\begin{tabular}{|c|c|c|c|c|c|c|c|c|c|c|c|c|c|}
\hline \multirow{3}{*}{$\begin{array}{c}\text { № } \\
\text { Caso }\end{array}$} & \multirow{3}{*}{$\begin{array}{c}\text { № AP } \\
\text { cistectomia }\end{array}$} & \multicolumn{12}{|c|}{ Imunoexpressão de MMP-9 } \\
\hline & & \multicolumn{3}{|c|}{ Global } & \multicolumn{3}{|c|}{$\begin{array}{l}\text { Tumor primário } \\
\text { Epitélio neoplásico }\end{array}$} & \multicolumn{3}{|c|}{ Estroma } & \multicolumn{3}{|c|}{$\begin{array}{l}\text { Metástase } \\
\text { linfonodal }\end{array}$} \\
\hline & & POS & INT & Escore & POS & INT & Escore & POS & INT & Escore & POS & INT & Escore \\
\hline 1 & $06-3117$ & 4 & 1 & 4 & 4 & 1 & 4 & 1 & 1 & 1 & 99 & 99 & 99 \\
\hline 2 & $06-4117$ & 3 & 1 & 3 & 3 & 1 & 3 & 0 & 0 & 0 & 8 & 1 & 8 \\
\hline 3 & $06-6382$ & 5 & 1 & 5 & 5 & 1 & 5 & 1 & 1 & 1 & 99 & 99 & 99 \\
\hline 4 & 06-11942 & 0 & 0 & 0 & 0 & 0 & 0 & 0 & 0 & 0 & 99 & 99 & 99 \\
\hline 5 & $06-13876$ & 8 & 2 & 16 & 8 & 2 & 16 & 1 & 2 & 2 & 99 & 99 & 99 \\
\hline 6 & 06-20929 & 0 & 0 & 0 & 0 & 0 & 0 & 0 & 0 & 0 & 0 & 0 & 0 \\
\hline 7 & $07-616$ & 5 & 2 & 10 & 5 & 1 & 5 & 5 & 2 & 10 & 3 & 1 & 3 \\
\hline 8 & 07-11085 & 1 & 1 & 1 & 1 & 1 & 1 & 1 & 1 & 1 & 98 & 98 & 98 \\
\hline 9 & 07-13565 & 7 & 1 & 7 & 7 & 1 & 7 & 5 & 1 & 5 & 99 & 99 & 99 \\
\hline 10 & $07-22483$ & 8 & 1 & 8 & 8 & 1 & 8 & 3 & 1 & 3 & 9 & 2 & 18 \\
\hline 11 & $07-25581$ & 2 & 2 & 4 & 0 & 0 & 0 & 2 & 2 & 4 & 99 & 99 & 99 \\
\hline 12 & $07-26735$ & 5 & 1 & 5 & 5 & 1 & 5 & 3 & 1 & 3 & 4 & 2 & 8 \\
\hline 13 & $07-29727$ & 3 & 2 & 6 & 4 & 1 & 4 & 3 & 2 & 6 & 1 & 1 & 1 \\
\hline 14 & $07-30656$ & 2 & 1 & 2 & 2 & 1 & 2 & 1 & 1 & 1 & 99 & 99 & 99 \\
\hline 15 & $07-31687$ & 6 & 1 & 6 & 6 & 1 & 6 & 2 & 1 & 2 & 99 & 99 & 99 \\
\hline 16 & $07-34067$ & 8 & 2 & 16 & 8 & 2 & 16 & 2 & 2 & 4 & 99 & 99 & 99 \\
\hline 17 & 07-36199 & 7 & 1 & 7 & 7 & 1 & 7 & 1 & 1 & 1 & 9 & 1 & 9 \\
\hline 18 & 07-39278 & 3 & 2 & 6 & 3 & 1 & 3 & 2 & 2 & 4 & 7 & 2 & 14 \\
\hline 19 & $07-42112$ & 3 & 2 & 6 & 3 & 1 & 3 & 2 & 2 & 4 & 99 & 99 & 99 \\
\hline 20 & $07-43120$ & 9 & 2 & 18 & 9 & 2 & 18 & 4 & 2 & 8 & 5 & 2 & 10 \\
\hline 21 & $07-43274$ & 7 & 2 & 14 & 7 & 1 & 7 & 5 & 2 & 10 & 99 & 99 & 99 \\
\hline 22 & $07-45145$ & 1 & 1 & 1 & 1 & 1 & 1 & 0 & 0 & 0 & 8 & 1 & 8 \\
\hline 23 & $08-2190$ & 1 & 1 & 1 & 1 & 1 & 1 & 1 & 1 & 1 & 0 & 0 & 0 \\
\hline 24 & 08-2909 & 3 & 2 & 6 & 3 & 1 & 3 & 3 & 2 & 6 & 8 & 2 & 16 \\
\hline 25 & 08-3167 & 1 & 1 & 1 & 1 & 1 & 1 & 1 & 1 & 1 & 99 & 99 & 99 \\
\hline 26 & $08-3322$ & 8 & 2 & 16 & 8 & 2 & 16 & 4 & 2 & 8 & 9 & 2 & 18 \\
\hline 27 & 08-3973 & 1 & 1 & 1 & 0 & 0 & 0 & 1 & 1 & 1 & 99 & 99 & 99 \\
\hline 28 & $08-13432$ & 6 & 1 & 6 & 6 & 1 & 6 & 1 & 1 & 1 & 2 & 1 & 2 \\
\hline 29 & 08-15012 & 4 & 2 & 8 & 3 & 1 & 3 & 4 & 2 & 8 & 99 & 99 & 99 \\
\hline 30 & $08-16864$ & 7 & 2 & 14 & 7 & 2 & 14 & 3 & 2 & 6 & 2 & 1 & 2 \\
\hline 31 & 08-17394 & 8 & 2 & 16 & 8 & 2 & 16 & 2 & 2 & 4 & 99 & 99 & 99 \\
\hline 32 & 08-20913 & 1 & 1 & 1 & 1 & 1 & 1 & 1 & 1 & 1 & 99 & 99 & 99 \\
\hline
\end{tabular}

Continua... 
Conclusão Anexo E

\begin{tabular}{|c|c|c|c|c|c|c|c|c|c|c|c|c|c|}
\hline \multirow{3}{*}{$\begin{array}{l}\text { № } \\
\text { Caso }\end{array}$} & \multirow{3}{*}{$\begin{array}{c}\text { № AP } \\
\text { cistectomia }\end{array}$} & \multicolumn{12}{|c|}{ Imunoexpressão de MMP-9 } \\
\hline & & \multicolumn{3}{|c|}{ Global } & \multicolumn{3}{|c|}{$\begin{array}{l}\text { Tumor primário } \\
\text { Epitélio neoplásico }\end{array}$} & \multicolumn{3}{|c|}{ Estroma } & \multicolumn{3}{|c|}{$\begin{array}{l}\text { Metástase } \\
\text { linfonodal }\end{array}$} \\
\hline & & POS & INT & Escore & POS & INT & Escore & POS & INT & Escore & POS & INT & Escore \\
\hline 33 & 08-21156 & 4 & 2 & 8 & 4 & 2 & 8 & 1 & 2 & 2 & 0 & 0 & 0 \\
\hline 34 & 08-23404 & 1 & 1 & 1 & 0 & 0 & 0 & 1 & 1 & 1 & 99 & 99 & 99 \\
\hline 35 & 08-29037 & 4 & 1 & 4 & 4 & 1 & 4 & 2 & 1 & 2 & 3 & 1 & 3 \\
\hline 36 & 08-33337 & 4 & 2 & 8 & 4 & 1 & 4 & 3 & 2 & 6 & 6 & 1 & 6 \\
\hline 37 & 08-38552 & 98 & 98 & 98 & 98 & 98 & 98 & 98 & 98 & 98 & 99 & 99 & 99 \\
\hline 38 & $08-43238$ & 6 & 2 & 12 & 6 & 1 & 6 & 4 & 2 & 8 & 4 & 1 & 4 \\
\hline 39 & 08-44312 & 3 & 1 & 3 & 3 & 1 & 3 & 0 & 0 & 0 & 98 & 98 & 98 \\
\hline 40 & $09-70$ & 2 & 1 & 2 & 2 & 1 & 2 & 2 & 1 & 2 & 2 & 1 & 2 \\
\hline 41 & 09-1537 & 1 & 1 & 1 & 1 & 1 & 1 & 1 & 1 & 1 & 0 & 0 & 0 \\
\hline 42 & $09-2641$ & 9 & 2 & 18 & 9 & 2 & 18 & 2 & 2 & 4 & 5 & 1 & 5 \\
\hline 43 & $09-2787$ & 5 & 1 & 5 & 5 & 1 & 5 & 2 & 1 & 2 & 99 & 99 & 99 \\
\hline 44 & $09-5522$ & 6 & 2 & 12 & 6 & 2 & 12 & 4 & 2 & 8 & 4 & 1 & 4 \\
\hline 45 & 09-8981 & 4 & 1 & 4 & 4 & 1 & 4 & 2 & 1 & 2 & 99 & 99 & 99 \\
\hline 46 & 09-11028 & 1 & 1 & 1 & 0 & 0 & 0 & 1 & 1 & 1 & 1 & 1 & 1 \\
\hline 47 & 09-14462 & 1 & 1 & 1 & 1 & 1 & 1 & 0 & 0 & 0 & 5 & 1 & 5 \\
\hline 48 & 09-14474 & 1 & 1 & 1 & 0 & 0 & 0 & 1 & 1 & 1 & 99 & 99 & 99 \\
\hline 49 & 09-19244 & 1 & 1 & 1 & 0 & 0 & 0 & 1 & 1 & 1 & 99 & 99 & 99 \\
\hline 50 & 09-31030 & 6 & 2 & 12 & 6 & 2 & 12 & 4 & 2 & 8 & 99 & 99 & 99 \\
\hline 51 & (28) 09-1669 & 6 & 2 & 12 & 6 & 2 & 12 & 6 & 2 & 12 & 8 & 2 & 16 \\
\hline 52 & (28) 09-2614 & 5 & 2 & 10 & 4 & 2 & 8 & 4 & 2 & 8 & 1 & 1 & 1 \\
\hline 53 & (28) 09-3439 & 1 & 1 & 1 & 1 & 1 & 1 & 0 & 0 & 0 & 99 & 99 & 99 \\
\hline 54 & (28) 09-3786 & 5 & 2 & 10 & 5 & 1 & 5 & 4 & 2 & 8 & 99 & 99 & 99 \\
\hline 55 & (28) 09-4090 & 8 & 2 & 16 & 8 & 2 & 16 & 3 & 2 & 6 & 8 & 2 & 16 \\
\hline 56 & 656634-0 & 2 & 1 & 2 & 2 & 1 & 2 & 1 & 1 & 1 & 99 & 99 & 99 \\
\hline 57 & $461071-7$ & 3 & 1 & 3 & 3 & 1 & 3 & 1 & 1 & 1 & 98 & 98 & 98 \\
\hline 58 & $673167-8$ & 1 & 1 & 1 & 1 & 1 & 1 & 1 & 1 & 1 & 99 & 99 & 99 \\
\hline 59 & $685272-6$ & 3 & 1 & 3 & 3 & 1 & 3 & 1 & 1 & 1 & 7 & 2 & 14 \\
\hline 60 & $691247-8$ & 0 & 0 & 0 & 0 & 0 & 0 & 0 & 0 & 0 & 1 & 1 & 1 \\
\hline 61 & $702478-9$ & 5 & 2 & 10 & 5 & 1 & 5 & 5 & 2 & 10 & 4 & 1 & 4 \\
\hline
\end{tabular}

MMP-9: Metaloproteinase de matriz 9; POS: Positividade da reação imuno-histoquímica; INT: intensidade da reação imuno-histoquímica; 98: perda de material/tecido não representativo nos cortes a partir do tissue microarray, 99: não avaliável neste caso (sem linfadenectomia/metástase ausente). 
Anexo F: Estudo imuno-histoquímico de MMP-14 - distribuição da positividade, intensidade e escore no tumor primário e na metástase linfonodal

\begin{tabular}{|c|c|c|c|c|c|c|c|c|c|c|c|c|c|}
\hline \multirow{3}{*}{$\begin{array}{c}\text { № } \\
\text { Caso }\end{array}$} & \multirow{3}{*}{$\begin{array}{c}\text { № } \text { AP } \\
\text { cistectomia }\end{array}$} & \multicolumn{12}{|c|}{ Imunoexpressão de MMP-14 } \\
\hline & & \multicolumn{9}{|c|}{ Tumor primário } & \multicolumn{3}{|c|}{$\begin{array}{l}\text { Metástase } \\
\text { linfonodal }\end{array}$} \\
\hline & & POS & INT & Escore & POS & INT & Escore & POS & INT & Escore & POS & INT & Escore \\
\hline 1 & 06-3117 & 2 & 1 & 2 & 2 & 1 & 2 & 1 & 1 & 1 & 99 & 99 & 99 \\
\hline 2 & $06-4117$ & 9 & 2 & 18 & 9 & 2 & 18 & 0 & 0 & 0 & 7 & 2 & 14 \\
\hline 3 & $06-6382$ & 8 & 2 & 16 & 8 & 2 & 16 & 1 & 1 & 1 & 99 & 99 & 99 \\
\hline 4 & 06-11942 & 2 & 1 & 2 & 1 & 1 & 1 & 2 & 1 & 2 & 99 & 99 & 99 \\
\hline 5 & $06-13876$ & 8 & 2 & 16 & 8 & 2 & 16 & 1 & 1 & 1 & 99 & 99 & 99 \\
\hline 6 & 06-20929 & 5 & 1 & 5 & 5 & 1 & 5 & 1 & 1 & 1 & 3 & 1 & 3 \\
\hline 7 & $07-616$ & 2 & 1 & 2 & 2 & 1 & 2 & 2 & 1 & 2 & 4 & 1 & 4 \\
\hline 8 & 07-11085 & 3 & 2 & 6 & 3 & 2 & 6 & 1 & 1 & 1 & 98 & 98 & 98 \\
\hline 9 & 07-13565 & 5 & 1 & 5 & 5 & 1 & 5 & 2 & 1 & 2 & 99 & 99 & 99 \\
\hline 10 & $07-22483$ & 9 & 2 & 18 & 9 & 2 & 18 & 9 & 2 & 18 & 8 & 2 & 16 \\
\hline 11 & $07-25581$ & 1 & 1 & 1 & 0 & 0 & 0 & 1 & 1 & 1 & 99 & 99 & 99 \\
\hline 12 & $07-26735$ & 6 & 2 & 12 & 6 & 2 & 12 & 3 & 2 & 6 & 4 & 2 & 8 \\
\hline 13 & $07-29727$ & 5 & 2 & 10 & 5 & 2 & 10 & 1 & 2 & 2 & 4 & 1 & 4 \\
\hline 14 & 07-30656 & 2 & 1 & 2 & 2 & 1 & 2 & 1 & 1 & 1 & 99 & 99 & 99 \\
\hline 15 & 07-31687 & 8 & 2 & 16 & 8 & 2 & 16 & 1 & 2 & 2 & 99 & 99 & 99 \\
\hline 16 & 07-34067 & 8 & 1 & 8 & 8 & 1 & 8 & 2 & 1 & 2 & 99 & 99 & 99 \\
\hline 17 & 07-36199 & 9 & 1 & 9 & 9 & 1 & 9 & 2 & 1 & 2 & 6 & 1 & 6 \\
\hline 18 & 07-39278 & 5 & 2 & 10 & 5 & 2 & 10 & 5 & 1 & 5 & 2 & 1 & 2 \\
\hline 19 & $07-42112$ & 3 & 1 & 3 & 1 & 1 & 1 & 3 & 1 & 3 & 99 & 99 & 99 \\
\hline 20 & $07-43120$ & 9 & 2 & 18 & 9 & 2 & 18 & 5 & 2 & 10 & 7 & 2 & 14 \\
\hline 21 & $07-43274$ & 8 & 2 & 16 & 8 & 2 & 16 & 4 & 2 & 8 & 99 & 99 & 99 \\
\hline 22 & 07-45145 & 3 & 1 & 3 & 3 & 1 & 3 & 1 & 1 & 1 & 5 & 2 & 10 \\
\hline 23 & $08-2190$ & 2 & 1 & 2 & 2 & 1 & 2 & 1 & 1 & 1 & 0 & 0 & 0 \\
\hline 24 & 08-2909 & 4 & 2 & 8 & 3 & 2 & 6 & 4 & 2 & 8 & 0 & 0 & 0 \\
\hline 25 & 08-3167 & 3 & 1 & 3 & 3 & 1 & 3 & 3 & 1 & 3 & 99 & 99 & 99 \\
\hline 26 & 08-3322 & 9 & 2 & 18 & 9 & 2 & 18 & 5 & 2 & 10 & 5 & 1 & 5 \\
\hline 27 & 08-3973 & 4 & 2 & 8 & 1 & 1 & 1 & 4 & 2 & 8 & 99 & 99 & 99 \\
\hline 28 & 08-13432 & 6 & 1 & 6 & 6 & 1 & 6 & 3 & 1 & 3 & 0 & 0 & 0 \\
\hline 29 & 08-15012 & 7 & 2 & 14 & 7 & 1 & 7 & 5 & 2 & 10 & 99 & 99 & 99 \\
\hline 30 & 08-16864 & 6 & 1 & 6 & 6 & 1 & 6 & 6 & 1 & 6 & 2 & 1 & 2 \\
\hline 31 & 08-17394 & 6 & 2 & 12 & 6 & 2 & 12 & 4 & 2 & 8 & 99 & 99 & 99 \\
\hline 32 & 08-20913 & 4 & 2 & 8 & 4 & 1 & 4 & 4 & 2 & 8 & 99 & 99 & 99 \\
\hline
\end{tabular}

Continua... 
Conclusão Anexo F

\begin{tabular}{|c|c|c|c|c|c|c|c|c|c|c|c|c|c|}
\hline \multirow{3}{*}{$\begin{array}{c}\text { № } \\
\text { Caso }\end{array}$} & \multirow{3}{*}{$\begin{array}{c}\text { № AP } \\
\text { cistectomia }\end{array}$} & \multicolumn{12}{|c|}{ Imunoexpressão de MMP-14 } \\
\hline & & \multicolumn{3}{|c|}{ Global } & \multicolumn{3}{|c|}{$\begin{array}{l}\text { Tumor primário } \\
\text { Epitélio neoplásico }\end{array}$} & \multicolumn{3}{|c|}{ Estroma } & \multicolumn{3}{|c|}{$\begin{array}{l}\text { Metástase } \\
\text { linfonodal }\end{array}$} \\
\hline & & POS & INT & Escore & POS & INT & Escore & POS & INT & Escore & POS & INT & Escore \\
\hline 33 & 08-21156 & 6 & 2 & 12 & 6 & 2 & 12 & 3 & 1 & 3 & 0 & 0 & 0 \\
\hline 34 & $08-23404$ & 3 & 2 & 6 & 3 & 1 & 3 & 2 & 2 & 4 & 99 & 99 & 99 \\
\hline 35 & 08-29037 & 4 & 1 & 4 & 4 & 1 & 4 & 2 & 1 & 2 & 2 & 1 & 2 \\
\hline 36 & 08-33337 & 2 & 1 & 2 & 1 & 1 & 1 & 2 & 1 & 2 & 5 & 1 & 5 \\
\hline 37 & 08-38552 & 98 & 98 & 98 & 98 & 98 & 98 & 98 & 98 & 98 & 99 & 99 & 99 \\
\hline 38 & $08-43238$ & 8 & 2 & 16 & 8 & 1 & 8 & 8 & 2 & 16 & 2 & 1 & 2 \\
\hline 39 & $08-44312$ & 6 & 2 & 12 & 6 & 2 & 12 & 1 & 1 & 1 & 98 & 98 & 98 \\
\hline 40 & $09-70$ & 3 & 2 & 6 & 3 & 1 & 3 & 3 & 2 & 6 & 5 & 1 & 5 \\
\hline 41 & 09-1537 & 1 & 1 & 1 & 1 & 1 & 1 & 1 & 1 & 1 & 1 & 1 & 1 \\
\hline 42 & $09-2641$ & 4 & 2 & 8 & 4 & 2 & 8 & 1 & 2 & 2 & 3 & 1 & 3 \\
\hline 43 & $09-2787$ & 3 & 1 & 3 & 3 & 1 & 3 & 3 & 1 & 3 & 99 & 99 & 99 \\
\hline 44 & $09-5522$ & 5 & 2 & 10 & 5 & 2 & 10 & 3 & 2 & 6 & 2 & 1 & 2 \\
\hline 45 & 09-8981 & 7 & 2 & 14 & 7 & 2 & 14 & 4 & 2 & 8 & 99 & 99 & 99 \\
\hline 46 & 09-11028 & 2 & 1 & 2 & 2 & 1 & 2 & 0 & 0 & 0 & 1 & 1 & 1 \\
\hline 47 & 09-14462 & 2 & 1 & 2 & 2 & 1 & 2 & 2 & 1 & 2 & 2 & 1 & 2 \\
\hline 48 & 09-14474 & 1 & 1 & 1 & 1 & 1 & 1 & 1 & 1 & 1 & 99 & 99 & 99 \\
\hline 49 & 09-19244 & 6 & 2 & 12 & 6 & 2 & 12 & 4 & 2 & 8 & 99 & 99 & 99 \\
\hline 50 & $09-31030$ & 3 & 1 & 3 & 1 & 1 & 1 & 3 & 1 & 3 & 99 & 99 & 99 \\
\hline 51 & (28) 09-1669 & 7 & 2 & 14 & 7 & 2 & 14 & 4 & 2 & 8 & 6 & 2 & 12 \\
\hline 52 & (28) 09-2614 & 8 & 2 & 16 & 8 & 2 & 16 & 4 & 2 & 8 & 98 & 98 & 98 \\
\hline 53 & (28) 09-3439 & 3 & 1 & 3 & 3 & 1 & 3 & 1 & 1 & 1 & 99 & 99 & 99 \\
\hline 54 & (28) 09-3786 & 6 & 2 & 12 & 6 & 1 & 6 & 5 & 2 & 10 & 99 & 99 & 99 \\
\hline 55 & (28) 09-4090 & 8 & 2 & 16 & 8 & 2 & 16 & 8 & 2 & 16 & 1 & 1 & 1 \\
\hline 56 & $656634-0$ & 3 & 1 & 3 & 1 & 1 & 1 & 3 & 1 & 3 & 99 & 99 & 99 \\
\hline 57 & $461071-7$ & 7 & 2 & 14 & 7 & 2 & 14 & 5 & 2 & 10 & 98 & 98 & 98 \\
\hline 58 & $673167-8$ & 2 & 1 & 2 & 2 & 1 & 2 & 2 & 1 & 2 & 99 & 99 & 99 \\
\hline 59 & $685272-6$ & 5 & 2 & 10 & 5 & 1 & 5 & 3 & 2 & 6 & 5 & 1 & 5 \\
\hline 60 & 691247-8 & 6 & 2 & 12 & 6 & 1 & 6 & 5 & 2 & 10 & 1 & 1 & 1 \\
\hline 61 & $702478-9$ & 7 & 2 & 14 & 7 & 2 & 14 & 7 & 2 & 14 & 5 & 1 & 5 \\
\hline
\end{tabular}

MMP-14: Metaloproteinase de matriz 14; POS: Positividade da reação imuno-histoquímica; INT: intensidade da reação imuno-histoquímica; 98: perda de material/tecido não representativo nos cortes a partir do tissue microarray, 99: não avaliável neste caso (sem linfadenectomia/metástase ausente). 


\section{REFERÊNCIAS}


1. Jemal A, Bray F, Center MM, Ferlay J, Ward E, Forman D. Global cancer statistics. CA Cancer J Clin. 2011 Mar-Apr;61(2):69-90.

2. Ferlay J, Shin HR, Bray F, Forman D, Mathers CD, Parkin D. GLOBOCAN 2008, Cancer Incidence and Mortality Worldwide: IARC CancerBase $\mathrm{N}^{0} 10$. Lyon, France: International Agency for Research on Cancer [Internet]. 2011 [cited 2011 Mar 26]. Available from: http://globocan.iarc.fr/.

3. Parkin DM. The global health burden of infection-associated cancers in the year 2002. Int J Cancer. 2006 Jun 15;118(12):3030-44.

4. Boffetta P. Tobacco smoking and risk of bladder cancer. Scand J Urol Nephrol Suppl. 2008 Sep(218):45-54.

5. Gandini S, Botteri E, lodice S, Boniol M, Lowenfels AB, Maisonneuve P, et al. Tobacco smoking and cancer: a meta-analysis. Int J Cancer. 2008 Jan 1;122(1):155-64.

6. Vineis P, Esteve J, Terracini B. Bladder cancer and smoking in males: types of cigarettes, age at start, effect of stopping and interaction with occupation. Int J Cancer. 1984 Aug 15;34(2):165-70.

7. Castelao JE, Yuan JM, Skipper PL, Tannenbaum SR, Gago-Dominguez M, Crowder JS, et al. Gender- and smoking-related bladder cancer risk. J Natl Cancer Inst. 2001 Apr 4;93(7):538-45.

8. Delclos GL, Lerner SP. Occupational risk factors. Scand J Urol Nephrol Suppl. $2008 \operatorname{Sep}(218): 58-63$.

9. Reulen RC, Kellen E, Buntinx F, Brinkman M, Zeegers MP. A metaanalysis on the association between bladder cancer and occupation. Scand J Urol Nephrol Suppl. 2008 Sep(218):64-78. 
10. Malats N. Genetic epidemiology of bladder cancer: scaling up in the identification of low-penetrance genetic markers of bladder cancer risk and progression. Scand J Urol Nephrol Suppl. 2008 Sep(218):131-40.

11. Garcia-Closas M, Malats N, Silverman D, Dosemeci M, Kogevinas M, Hein DW, et al. NAT2 slow acetylation, GSTM1 null genotype, and risk of bladder cancer: results from the Spanish Bladder Cancer Study and meta-analyses. Lancet. 2005 Aug 20-26;366(9486):649-59.

12. Lopez-Beltran A, Sauter G, Gasser T, Hartmann A, Schmitz-Dra“ger BJ, Helpap $B$, et al. Urothelial tumors: infiltrating urothelial carcinoma. In: Eble JN, Sauter G, Epstein JI, Sesterhenn IA, editors. World Health Organization classification of tumors: pathology and genetics of tumors of the urinary system and male genital organs. Lyon: IARC Press; 2004.

13. Montironi R, Mazzucchelli R, Scarpelli M, Lopez-Beltran A, Cheng L. Morphological diagnosis of urothelial neoplasms. J Clin Pathol. 2008 Jan;61(1):3-10.

14. Epstein JI, Amin MB, Reuter VR, Mostofi FK. The World Health Organization/International Society of Urological Pathology consensus classification of urothelial (transitional cell) neoplasms of the urinary bladder. Bladder Consensus Conference Committee. Am J Surg Pathol. 1998 Dec;22(12):1435-48.

15. Sauter G, Algaba F, Amin MB, Busch C, Cheville J, Gasser T, et al. Non-invasive urothelial neoplasias. In: Eble JN, Sauter G, Epstein JI, Sesterhenn IA, editors. World Health Organization classification of tumors: pathology and genetics of tumors of the urinary system and male genital organs. Lyon: IARC Press; 2004.

16. Lopez-Beltran A, Montironi R. Non-invasive urothelial neoplasms: according to the most recent WHO classification. Eur Urol. 2004 Aug;46(2):170-6.

17. Holmang S, Johansson SL. Stage Ta-T1 bladder cancer: the relationship between findings at first followup cystoscopy and subsequent recurrence and progression. J Urol. 2002 Apr;167(4):1634-7.

18. Lopez-Beltran A. Bladder cancer: clinical and pathological profile. Scand J Urol Nephrol Suppl. 2008 Sep(218):95-109. 
19. Lebret T, Bohin D, Kassardjian Z, Herve JM, Molinie V, Barre P, et al. Recurrence, progression and success in stage Ta grade 3 bladder tumors treated with low dose bacillus Calmette-Guerin instillations. $J$ Urol. 2000 Jan;163(1):63-7.

20. Amin MB, Delahunt B, Bochner BH, Epstein JI, Grignon DJ, Montironi R, Paner GP, Renshaw AA, Reuter VE, Srigley JR, Humphrey PA, for the members of the Cancer Committee, College of American Pathologists. Protocol for the Examination of Specimens from Patients with Carcinoma of the Urinary Bladder. College of American Pathologists [Internet]. 2011 [cited 2011 May 8]. Available from: http://www.cap.org/apps/docs/committees/cancer/cancer_protocols/201 1/ UrinaryBladder_11 protocol.pdf.

21. Droller MJ. Bladder cancer: state-of-the-art care. CA Cancer J Clin. 1998 Sep-Oct;48(5):269-84.

22. Millan-Rodriguez F, Chechile-Toniolo G, Salvador-Bayarri J, Palou J, Vicente-Rodriguez $\mathrm{J}$. Multivariate analysis of the prognostic factors of primary superficial bladder cancer. J Urol. 2000 Jan;163(1):73-8.

23. Cheng L, Weaver AL, Leibovich BC, Ramnani DM, Neumann RM, Scherer BG, et al. Predicting the survival of bladder carcinoma patients treated with radical cystectomy. Cancer. 2000 May 15;88(10):2326-32.

24. Jimenez RE, Gheiler E, Oskanian P, Tiguert R, Sakr W, Wood DP, Jr., et al. Grading the invasive component of urothelial carcinoma of the bladder and its relationship with progression-free survival. Am J Surg Pathol. 2000 Jul;24(7):980-7.

25. Langner C, Hutterer G, Chromecki T, Rehak P, Zigeuner R. Patterns of invasion and histological growth as prognostic indicators in urothelial carcinoma of the upper urinary tract. Virchows Arch. 2006 May;448(5):604-11.

26. Amin MB. Histological variants of urothelial carcinoma: diagnostic, therapeutic and prognostic implications. Mod Pathol. 2009 Jun;22 Suppl 2:S96-S118. 
27. Sylvester RJ, van der Meijden A, Witjes JA, Jakse G, Nonomura N, Cheng $C$, et al. High-grade Ta urothelial carcinoma and carcinoma in situ of the bladder. Urology. 2005 Dec;66(6 Suppl 1):90-107.

28. Lamm DL. Carcinoma in situ. Urol Clin North Am. 1992 Aug; 19(3):499-508.

29. Tilki D, Reich O, Svatek RS, Karakiewicz PI, Kassouf W, Novara G, et al. Characteristics and outcomes of patients with clinical carcinoma in situ only treated with radical cystectomy: an international study of 243 patients. J Urol. 2010 May;183(5):1757-63.

30. Cordon-Cardo C. Molecular alterations associated with bladder cancer initiation and progression. Scand J Urol Nephrol Suppl. 2008 Sep(218):154-65.

31. Lopez-Beltran A, Ordonez JL, Otero AP, Blanca A, Sevillano V, Sanchez-Carbayo $M$, et al. Cyclin D3 gene amplification in bladder carcinoma in situ. Virchows Arch. 2010 Nov;457(5):555-61.

32. Lotan Y, Gupta A, Shariat SF, Palapattu GS, Vazina A, Karakiewicz PI, et al. Lymphovascular invasion is independently associated with overall survival, cause-specific survival, and local and distant recurrence in patients with negative lymph nodes at radical cystectomy. J Clin Oncol. 2005 Sep 20;23(27):6533-9.

33. Resnick MJ, Bergey M, Magerfleisch L, Tomaszewski JE, Malkowicz SB, Guzzo TJ. Longitudinal evaluation of the concordance and prognostic value of lymphovascular invasion in transurethral resection and radical cystectomy specimens. BJU Int. 2011 Jan;107(1):46-52.

34. Cheng L, Montironi R, Davidson DD, Lopez-Beltran A. Staging and reporting of urothelial carcinoma of the urinary bladder. Mod Pathol. 2009 Jun;22 Suppl 2:S70-95.

35. Tosoni I, Wagner U, Sauter G, Egloff M, Knonagel H, Alund G, et al. Clinical significance of interobserver differences in the staging and grading of superficial bladder cancer. BJU Int. 2000 Jan;85(1):48-53.

36. Bol MG, Baak JP, Buhr-Wildhagen S, Kruse AJ, Kjellevold KH, Janssen $\mathrm{EA}$, et al. Reproducibility and prognostic variability of grade and lamina 
propria invasion in stages $\mathrm{Ta}, \mathrm{T} 1$ urothelial carcinoma of the bladder. $J$ Urol. 2003 Apr;169(4):1291-4.

37. Wu XR. Urothelial tumorigenesis: a tale of divergent pathways. Nat Rev Cancer. 2005 Sep;5(9):713-25.

38. Lindgren D, Liedberg F, Andersson A, Chebil G, Gudjonsson S, Borg A, et al. Molecular characterization of early-stage bladder carcinomas by expression profiles, FGFR3 mutation status, and loss of 9q. Oncogene. 2006 Apr 27;25(18):2685-96.

39. Shariat SF, Tokunaga H, Zhou J, Kim J, Ayala GE, Benedict WF, et al. p53, p21, pRB, and p16 expression predict clinical outcome in cystectomy with bladder cancer. J Clin Oncol. 2004 Mar 15; 22(6):1014-24.

40. Cheng L, Zhang S, MacLennan GT, Williamson SR, Lopez-Beltran A, Montironi R. Bladder cancer: translating molecular genetic insights into clinical practice. Hum Pathol. 2011 Apr;42(4):455-81.

41. Korkolopoulou $\mathrm{P}$, Christodoulou $\mathrm{P}$, Kapralos $\mathrm{P}$, Exarchakos $\mathrm{M}$, Bisbiroula A, Hadjiyannakis M, et al. The role of p53, MDM2 and c-erb B-2 oncoproteins, epidermal growth factor receptor and proliferation markers in the prognosis of urinary bladder cancer. Pathol Res Pract. 1997;193(11-12):767-75.

42. Simon R, Struckmann $K$, Schraml $P$, Wagner U, Forster $T$, Moch $H$, et al. Amplification pattern of 12q13-q15 genes (MDM2, CDK4, GLI) in urinary bladder cancer. Oncogene. 2002 Apr 11;21(16):2476-83.

43. Hayashi N, Cunha GR. Mesenchyme-induced changes in the neoplastic characteristics of the Dunning prostatic adenocarcinoma. Cancer Res. 1991 Sep 15;51(18):4924-30.

44. Olumi AF, Grossfeld GD, Hayward SW, Carroll PR, Tlsty TD, Cunha GR. Carcinoma-associated fibroblasts direct tumor progression of initiated human prostatic epithelium. Cancer Res. 1999 Oct 1;59(19):5002-11.

45. Joyce JA, Pollard JW. Microenvironmental regulation of metastasis. Nat Rev Cancer. 2009 Apr;9(4):239-52. 
46. Allen $M$, Louise Jones J. Jekyll and Hyde: the role of the microenvironment on the progression of cancer. J Pathol. 2011 Jan;223(2):162-76.

47. Holliday DL, Hughes S, Shaw JA, Walker RA, Jones JL. Intrinsic genetic characteristics determine tumor-modifying capacity of fibroblasts: matrix metalloproteinase-3 5A/5A genotype enhances breast cancer cell invasion. Breast Cancer Res. 2007;9(5):R67.

48. Egeblad $M$, Werb $Z$. New functions for the matrix metalloproteinases in cancer progression. Nat Rev Cancer. 2002 Mar;2(3):161-74.

49. Gutierrez-Fernandez A, Fueyo A, Folgueras AR, Garabaya C, Pennington CJ, Pilgrim S, et al. Matrix metalloproteinase-8 functions as a metastasis suppressor through modulation of tumor cell adhesion and invasion. Cancer Res. 2008 Apr 15;68(8):2755-63.

50. Talmadge JE, Donkor M, Scholar E. Inflammatory cell infiltration of tumors: Jekyll or Hyde. Cancer Metastasis Rev. 2007 Dec;26(3-4):373-400.

51. Bingle L, Brown NJ, Lewis CE. The role of tumour-associated macrophages in tumour progression: implications for new anticancer therapies. J Pathol. 2002 Mar;196(3):254-65.

52. Murphy G. Fell-Muir Lecture: Metalloproteinases: from demolition squad to master regulators. Int J Exp Pathol. 2010 Aug;91(4):303-13.

53. Masson R, Lefebvre O, Noel A, Fahime ME, Chenard MP, Wendling C, et al. In vivo evidence that the stromelysin-3 metalloproteinase contributes in a paracrine manner to epithelial cell malignancy. $J$ Cell Biol. 1998 Mar 23;140(6):1535-41.

54. Coussens LM, Tinkle CL, Hanahan D, Werb Z. MMP-9 supplied by bone marrow-derived cells contributes to skin carcinogenesis. Cell. 2000 Oct 27;103(3):481-90.

55. Wallard MJ, Pennington CJ, Veerakumarasivam A, Burtt G, Mills IG, Warren $A$, et al. Comprehensive profiling and localisation of the matrix metalloproteinases in urothelial carcinoma. $\mathrm{Br} J$ Cancer. 2006 Feb 27;94(4):569-77. 
56. Polette M, Gilbert N, Stas I, Nawrocki B, Noel A, Remacle A, et al. Gelatinase A expression and localization in human breast cancers. An in situ hybridization study and immunohistochemical detection using confocal microscopy. Virchows Arch. 1994;424(6):641-5.

57. Kanayama H, Yokota K, Kurokawa Y, Murakami Y, Nishitani M, Kagawa S. Prognostic values of matrix metalloproteinase-2 and tissue inhibitor of metalloproteinase-2 expression in bladder cancer. Cancer. 1998 Apr 1;82(7):1359-66.

58. Geng J, Fan J, Wang P, Fang ZJ, Xia GW, Jiang HW, et al. REG1A predicts recurrence in stage Ta/T1 bladder cancer. Eur $J$ Surg Oncol. 2009 Aug;35(8):852-7.

59. Papathoma AS, Petraki C, Grigorakis A, Papakonstantinou H, Karavana $\mathrm{V}$, Stefanakis $\mathrm{S}$, et al. Prognostic significance of matrix metalloproteinases 2 and 9 in bladder cancer. Anticancer Res. 2000 May-Jun;20(3B):2009-13.

60. Habuchi T, Marberger M, Droller MJ, Hemstreet GP, 3rd, Grossman HB, Schalken JA, et al. Prognostic markers for bladder cancer: International Consensus Panel on bladder tumor markers. Urology. 2005 Dec;66(6 Suppl 1):64-74.

61. Guarino M, Rubino B, Ballabio $G$. The role of epithelial-mesenchymal transition in cancer pathology. Pathology. 2007 Jun;39(3):305-18.

62. Polyak K, Weinberg RA. Transitions between epithelial and mesenchymal states: acquisition of malignant and stem cell traits. Nat Rev Cancer. 2009 Apr;9(4):265-73.

63. Sabbah M, Emami S, Redeuilh G, Julien S, Prevost G, Zimber A, et al. Molecular signature and therapeutic perspective of the epithelial-tomesenchymal transitions in epithelial cancers. Drug Resist Updat. 2008 Aug-Oct;11(4-5):123-51.

64. Sternlicht MD, Lochter A, Sympson CJ, Huey B, Rougier JP, Gray JW, et al. The stromal proteinase MMP3/stromelysin-1 promotes mammary carcinogenesis. Cell. 1999 Jul 23;98(2):137-46.

65. McCawley LJ, Matrisian LM. Matrix metalloproteinases: multifunctional contributors to tumor progression. Mol Med Today. 2000 Apr;6(4):149-56. 
66. Slaton JW, Millikan R, Inoue K, Karashima T, Czerniak B, Shen Y, et al. Correlation of metastasis related gene expression and relapse-free survival in patients with locally advanced bladder cancer treated with cystectomy and chemotherapy. J Urol. 2004 Feb;171(2 Pt 1):570-4.

67. Nigwekar $\mathrm{P}$, Amin MB. The many faces of urothelial carcinoma: an update with an emphasis on recently described variants. Adv Anat Pathol. 2008 Jul;15(4):218-33.

68. Edge SB, Byrd DR, Compton CC, Fritz AG, Greene FL, Trotti A III, editor. AJCC Cancer Staging Manual. $7^{\text {th }}$. New York: Springer; 2010.

69. Kononen J, Bubendorf L, Kallioniemi A, Barlund M, Schraml P, Leighton $\mathrm{S}$, et al. Tissue microarrays for high-throughput molecular profiling of tumor specimens. Nat Med. 1998 Jul;4(7):844-7.

70. DiVito KA, Charette LA, Rimm DL, Camp RL. Long-term preservation of antigenicity on tissue microarrays. Lab Invest. 2004 Aug;84(8):1071-8.

71. McCarty KS, Jr., Miller LS, Cox EB, Konrath J, McCarty KS, Sr. Estrogen receptor analyses. Correlation of biochemical and immunohistochemical methods using monoclonal antireceptor antibodies. Arch Pathol Lab Med. 1985 Aug;109(8):716-21.

72. Hammond ME, Hayes DF, Dowsett M, Allred DC, Hagerty KL, Badve S, et al. American Society of Clinical Oncology/College of American Pathologists guideline recommendations for immunohistochemical testing of estrogen and progesterone receptors in breast cancer. Arch Pathol Lab Med. 2010 Jun;134(6):907-22.

73. Ulbright TM, Hattab EM, Zhang S, Ehrlich Y, Foster RS, Einhorn LH, et al. Primitive neuroectodermal tumors in patients with testicular germ cell tumors usually resemble pediatric-type central nervous system embryonal neoplasms and lack chromosome 22 rearrangements. Mod Pathol. 2010 Jul;23(7):972-80.

74. Uloza V, Liutkevicius V, Pangonyte D, Saferis V, Lesauskaite V. Expression of matrix metalloproteinases (MMP-2 and MMP-9) in recurrent respiratory papillomas and laryngeal carcinoma: clinical and morphological parallels. Eur Arch Otorhinolaryngol. 2011 Jun;268(6):871-8. 
75. Nocito A, Bubendorf L, Tinner EM, Suess K, Wagner U, Forster T, et al. Microarrays of bladder cancer tissue are highly representative of proliferation index and histological grade. J Pathol. 2001 Jul;194(3):349-57.

76. Kocher T, Zheng M, Bolli M, Simon R, Forster T, Schultz-Thater E, et al. Prognostic relevance of MAGE-A4 tumor antigen expression in transitional cell carcinoma of the urinary bladder: a tissue microarray study. Int J Cancer. 2002 Aug 20;100(6):702-5.

77. Cregger M, Berger AJ, Rimm DL. Immunohistochemistry and quantitative analysis of protein expression. Arch Pathol Lab Med. 2006 Jul;130(7):1026-30.

78. Kassouf W, Svatek RS, Shariat SF, Novara G, Lerner SP, Fradet Y, et al. Critical analysis and validation of lymph node density as prognostic variable in urothelial carcinoma of bladder. Urol Oncol. $2011 \mathrm{Apr} 7$.

79. Nakai Y, Nonomura N, Kawashima A, Mukai M, Nagahara A, Nakayama $M$, et al. Tumor multiplicity is an independent prognostic factor of non-muscle-invasive high-grade (T1G3) bladder cancer. Jpn J Clin Oncol. 2010 Mar;40(3):252-7.

80. van Rhijn BW, Burger M, Lotan Y, Solsona E, Stief CG, Sylvester RJ, et al. Recurrence and progression of disease in non-muscle-invasive bladder cancer: from epidemiology to treatment strategy. Eur Urol. 2009 Sep;56(3):430-42.

81. Youssef RF, Lotan Y. Predictors of outcome of non-muscle-invasive and muscle-invasive bladder cancer. ScientificWorldJournal. 2011;11:369-81.

82. Fung $\mathrm{CY}$, Shipley WU, Young RH, Griffin PP, Convery KM, Kaufman DS, et al. Prognostic factors in invasive bladder carcinoma in a prospective trial of preoperative adjuvant chemotherapy and radiotherapy. J Clin Oncol. 1991 Sep;9(9):1533-42.

83. Vasala K, Paakko $\mathrm{P}$, Turpeenniemi-Hujanen T. Matrix metalloproteinase-2 immunoreactive protein as a prognostic marker in bladder cancer. Urology. 2003 Nov;62(5):952-7. 
84. Grignon DJ, Sakr W, Toth M, Ravery V, Angulo J, Shamsa F, et al. High levels of tissue inhibitor of metalloproteinase-2 (TIMP-2) expression are associated with poor outcome in invasive bladder cancer. Cancer Res. 1996 Apr 1;56(7):1654-9.

85. Gupta R, Paner GP, Amin MB. Neoplasms of the upper urinary tract: a review with focus on urothelial carcinoma of the pelvicalyceal system and aspects related to its diagnosis and reporting. Adv Anat Pathol. 2008 May; 15(3):127-39.

86. van Rhijn BW, Lurkin I, Radvanyi F, Kirkels WJ, van der Kwast TH, Zwarthoff EC. The fibroblast growth factor receptor 3 (FGFR3) mutation is a strong indicator of superficial bladder cancer with low recurrence rate. Cancer Res. 2001 Feb 15;61(4):1265-8.

87. Bakkar AA, Wallerand H, Radvanyi F, Lahaye JB, Pissard S, Lecerf L, et al. FGFR3 and TP53 gene mutations define two distinct pathways in urothelial cell carcinoma of the bladder. Cancer Res. 2003 Dec 1;63(23):8108-12.

88. Schulz WA. Understanding urothelial carcinoma through cancer pathways. Int J Cancer. 2006 Oct 1;119(7):1513-8.

89. Black PC, Brown GA, Dinney CP. The impact of variant histology on the outcome of bladder cancer treated with curative intent. Urol Oncol. 2009 Jan-Feb;27(1):3-7.

90. Planaguma J, Liljestrom M, Alameda F, Butzow R, Virtanen I, Reventos $\mathrm{J}$, et al. Matrix metalloproteinase-2 and matrix metalloproteinase-9 codistribute with transcription factors RUNX1/AML1 and ETV5/ERM at the invasive front of endometrial and ovarian carcinoma. Hum Pathol. 2011 Jan;42(1):57-67.

91. Trudel D, Fradet Y, Meyer F, Tetu B. Matrix metalloproteinase 9 is associated with Gleason score in prostate cancer but not with prognosis. Hum Pathol. 2010 Dec;41(12):1694-701.

92. Lopez-Beltran A, Cheng L. Histologic variants of urothelial carcinoma: differential diagnosis and clinical implications. Hum Pathol. 2006 Nov;37(11):1371-88. 
93. Cheng L, Pan CX, Yang XJ, Lopez-Beltran A, MacLennan GT, Lin H, et al. Small cell carcinoma of the urinary bladder: a clinicopathologic analysis of 64 patients. Cancer. 2004 Sep 1;101(5):957-62.

94. Kamat AM, Gee JR, Dinney CP, Grossman HB, Swanson DA, Millikan $\mathrm{RE}$, et al. The case for early cystectomy in the treatment of nonmuscle invasive micropapillary bladder carcinoma. J Urol. $2006 \mathrm{Mar} ; 175(3 \mathrm{Pt}$ 1):881-5.

95. Sonpavde G, Khan MM, Svatek RS, Lee R, Novara G, Tilki D, et al. Prognostic risk stratification of pathological stage T3N0 bladder cancer after radical cystectomy. J Urol. 2011 Apr;185(4):1216-21.

96. Raffetto JD, Khalil RA. Matrix metalloproteinases and their inhibitors in vascular remodeling and vascular disease. Biochem Pharmacol. 2008 Jan 15;75(2):346-59.

97. Rundhaug JE. Matrix metalloproteinases and angiogenesis. J Cell Mol Med. 2005 Apr-Jun;9(2):267-85.

98. Antunes AA, Nesrallah LJ, Dall'Oglio MF, Crippa A, Nesrallah AJ, Paranhos $M$, et al. Perineural invasion by transitional cell carcinoma of the bladder in patients submitted to radical cystectomy: what is the prognostic value? Int Braz J Urol. 2007 Mar-Apr;33(2):161-6.

99. Shariat SF, Karakiewicz PI, Palapattu GS, Lotan Y, Rogers CG, Amiel $\mathrm{GE}$, et al. Outcomes of radical cystectomy for transitional cell carcinoma of the bladder: a contemporary series from the Bladder Cancer Research Consortium. J Urol. 2006 Dec;176(6 Pt 1):2414-22; discussion 22.

100. Davies B, Waxman J, Wasan H, Abel P, Williams G, Krausz T, et al. Levels of matrix metalloproteases in bladder cancer correlate with tumor grade and invasion. Cancer Res. 1993 Nov 15;53(22):5365-9.

101. Vasala K, Paakko P, Turpeenniemi-Hujanen T. Matrix metalloproteinase-9 (MMP-9) immunoreactive protein in urinary bladder cancer: a marker of favorable prognosis. Anticancer Res. 2008 May-Jun;28(3B):1757-61. 
102. Black PC, Dinney CP. Bladder cancer angiogenesis and metastasis-translation from murine model to clinical trial. Cancer Metastasis Rev. 2007 Dec;26(3-4):623-34.

103. Rakha EA, Reis-Filho JS, Baehner F, Dabbs DJ, Decker T, Eusebi V, et al. Breast cancer prognostic classification in the molecular era: the role of histological grade. Breast Cancer Res. 2010;12(4):207.

104. Lopez-Beltran A, Requena MJ, Alvarez-Kindelan J, Quintero A, Blanca A, Montironi R. Squamous differentiation in primary urothelial carcinoma of the urinary tract as seen by MAC387 immunohistochemistry. J Clin Pathol. 2007 Mar;60(3):332-5.

105. Lopez-Beltran A, Martin J, Garcia J, Toro M. Squamous and glandular differentiation in urothelial bladder carcinomas. Histopathology, histochemistry and immunohistochemical expression of carcinoembryonic antigen. Histol Histopathol. 1988 Jan;3(1):63-8.

106. Lopez-Beltran A, Pacelli A, Rothenberg HJ, Wollan PC, Zincke H, Blute $\mathrm{ML}$, et al. Carcinosarcoma and sarcomatoid carcinoma of the bladder: clinicopathological study of 41 cases. J Urol. 1998 May;159(5):1497-503.

107. Torenbeek R, Blomjous CE, de Bruin PC, Newling DW, Meijer CJ. Sarcomatoid carcinoma of the urinary bladder. Clinicopathologic analysis of 18 cases with immunohistochemical and electron microscopic findings. Am J Surg Pathol. 1994 Mar;18(3):241-9.

108. Wang J, Wang FW, Lagrange CA, Hemstreet lii GP, Kessinger A. Clinical features of sarcomatoid carcinoma (carcinosarcoma) of the urinary bladder: analysis of 221 cases. Sarcoma. 2010;2010.

109. Cheng L, Zhang S, Alexander R, Maclennan GT, Hodges KB, Harrison BT, et al. Sarcomatoid carcinoma of the urinary bladder: the final common pathway of urothelial carcinoma dedifferentiation. Am J Surg Pathol. 2011 May;35(5):e34-46.

110. McConkey DJ, Lee S, Choi W, Tran M, Majewski T, Siefker-Radtke A, et al. Molecular genetics of bladder cancer: Emerging mechanisms of tumor initiation and progression. Urol Oncol. 2010 Jul-Aug;28(4):429-40. 
111. Ikegami $H$, Iwasaki $H$, Ohjimi $Y$, Takeuchi $T$, Ariyoshi A, Kikuchi $M$. Sarcomatoid carcinoma of the urinary bladder: a clinicopathologic and immunohistochemical analysis of 14 patients. Hum Pathol. 2000 Mar;31(3):332-40.

112. Barr S, Thomson S, Buck E, Russo S, Petti F, Sujka-Kwok I, et al. Bypassing cellular EGF receptor dependence through epithelial-tomesenchymal-like transitions. Clin Exp Metastasis. 2008;25(6):685-93.

113. Matsui Y, Assi K, Ogawa O, Raven PA, Dedhar S, Gleave ME, et al. The importance of integrin-linked kinase in the regulation of bladder cancer invasion. Int J Cancer. 2011 Feb 23.

114. Strongin AY, Collier I, Bannikov G, Marmer BL, Grant GA, Goldberg GI. Mechanism of cell surface activation of 72-kDa type IV collagenase. Isolation of the activated form of the membrane metalloprotease. J Biol Chem. 1995 Mar 10;270(10):5331-8.

115. Vu TH, Shipley JM, Bergers G, Berger JE, Helms JA, Hanahan D, et al. MMP-9/gelatinase $B$ is a key regulator of growth plate angiogenesis and apoptosis of hypertrophic chondrocytes. Cell. 1998 May 1;93(3):411-22.

116. Zhou Z, Apte SS, Soininen R, Cao R, Baaklini GY, Rauser RW, et al. Impaired endochondral ossification and angiogenesis in mice deficient in membrane-type matrix metalloproteinase I. Proc Natl Acad Sci U S A. 2000 Apr 11;97(8):4052-7.

117. Fang J, Shing Y, Wiederschain D, Yan L, Butterfield C, Jackson G, et al. Matrix metalloproteinase-2 is required for the switch to the angiogenic phenotype in a tumor model. Proc Natl Acad Sci U S A. 2000 Apr 11:97(8):3884-9. 
APÊNDICE 


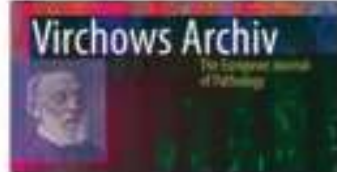

\section{Springer}

\section{Matrix metalloproteinases and divergent differentiation in urothelial carcinoma of the urinary bladder: a morphological and immunohistochemical study}

\begin{tabular}{|c|c|}
\hline Journal: & Virchows Archiv \\
\hline Manuscript ID: & Draft \\
\hline Type of Manuscript: & Original Article \\
\hline $\begin{array}{l}\text { Date Submitted by the } \\
\text { Author: }\end{array}$ & $\mathrm{n} / \mathrm{a}$ \\
\hline Complete List of Authors: & $\begin{array}{l}\text { Mattedi, Romulo; University of Sao Paulo School of Medicine, } \\
\text { Department of Pathology/LIM-14 } \\
\text { Espírito-Santo, Kleber; University of Sao Paulo School of Medicine, } \\
\text { Department of Pathology/LIM-14 } \\
\text { Wakamatsu, Alda; University of Sao Paulo School of Medicine, } \\
\text { Department of Pathology/LIM-14 } \\
\text { Dall'Oglio, Marcos Francisco; University of Sao Paulo School of } \\
\text { Medicine, Discipline of Urology, Department of Surgery } \\
\text { Srougi, Miguel; University of Sao Paulo School of Medicine, } \\
\text { Discipline of Urology, Department of Surgery } \\
\text { Alves, Venâncio; University of Sao Paulo School of Medicine, } \\
\text { Department of Pathology/LIM-14 }\end{array}$ \\
\hline General Pathology: & $\begin{array}{l}\text { tumor pathology (inc. classification grading prognosis invasion and } \\
\text { metastasis), extracellular matrix }\end{array}$ \\
\hline Systemic Pathology: & urinary tract (exl. kidney) \\
\hline $\begin{array}{r}\text { Special Techniques in } \\
\text { Pathology: }\end{array}$ & immunohistochemistry \\
\hline Free Keywords: & $\begin{array}{l}\text { Bladder urinary carcinoma, Matrix metalloproteinases (MMP), } \\
\text { Divergent differentiation }\end{array}$ \\
\hline $\begin{array}{r}\text { Keywords (old), please do } \\
\text { not select: }\end{array}$ & \\
\hline
\end{tabular}

\section{SCHOLARONE ${ }^{\text {M }}$


Matrix metalloproteinases and divergent differentiation in urothelial carcinoma of the urinary bladder: a morphological and immunohistochemical study

Authors

Romulo Loss Mattedi, MD ${ }^{1}$

Kleber Simões do Espírito Santo, $\mathrm{MD}, \mathrm{PhD}^{1}$

Alda Wakamatsu, MSc ${ }^{1}$

Marcos Francisco Dall'Oglio, $\mathrm{MD}, \mathrm{PhD}^{2}$

Miguel Srougi, $\mathrm{MD}, \mathrm{PhD}^{2}$

Venâncio Avancini Ferreira Alves, $\mathrm{MD}, \mathrm{PhD}^{1}$

${ }^{1}$ Department of Pathology/LIM-14, University of Sao Paulo School of Medicine, Brazil

${ }^{2}$ Discipline of Urology, Department of Surgery, University of Sao Paulo School of Medicine, Brazil

Corresponding author: Romulo Loss Mattedi, MD

e-mail: rlmattedi@hotmail.com

tel: $+55113061-7114,+55113069-6091$ 


\begin{abstract}
Histopathological study of urothelial carcinoma, the gold standard for the assessment of diagnosis and prognosis, yields the identification of several relevant variables, including the presence of areas of divergent differentiation. Several matrix metalloproteinases (MMPs) have been implicated in extracellular matrix digestion and in regulation of growth factor activity. In this study, tissue samples from 61 muscle-invasive or locally advanced urothelial carcinomas of the bladder arranged in tissue microarray were assessed for specific morphological aspects as associated to immunohistochemical expression to MMP-2, MMP-9 and MMP-14 in neoplastic epithelium and in stromal cells of the primary tumor and in lymph node metastases. The immunoexpression of the three MMPs in different compartments of the primary tumours were significantly associated with architectural pattern of tumor invasion, in special to infiltrative pattern. Immunoexpression to MMP-9 also was related with the presence of sarcomatoid component (expression in stroma cells, $\mathrm{p}=0.036$ ) and squamous differentiation (global expression, $\mathrm{p}=0.033$ ). In the lymph nodes metastases, immunoexpression of MMP-9 was directly related to the presence of histological variants in the primary tumors $(\mathrm{p}=0.021)$. Our results demonstrate that the immunoexpression of MMPs are associated with the divergent differentiation and to special morphological features of the urothelial carcinomas. These aspects could identify subgroups of bladder tumors where the differential expression of MMPs could indicate more likely progression and thus assist in the search for more effective on therapy for these patients.
\end{abstract}

\title{
Keywords
}

Bladder urinary carcinoma. Matrix metalloproteinases (MMP). Divergent differentiation. Sarcomatoid carcinoma. Epithelial- mesenchymal transition (EMT) 


\section{Introduction}

Urinary bladder neoplasms most commonly present evidences of urothelial lineage. Based on the GLOBOCAN estimates, about 386,300 new cases and 150,200 deaths from bladder cancer occurred in 2008 worldwide [1]. Most patients (75\%) present with superficial (pTa and pT1) tumors and have a 5-year survival rate around 88 to $98 \%$. In contrast, the 5-year survival rate for patients presenting with muscle invasive disease (pT2-pT4) is 46-63\%. Morphological features such as histological grade, tumor size, pattern of tumoral invasion, lymphovascular invasion and morphological variants, and also tumor stage, have been associated to disease evolution [2-7].

Tumor microenvironment exerts important functions during cancer development and progression. Among the important elements of microenvironment regulation, matrix metalloproteinases (MMP), reported to be produced by both neoplastic and by stromal cells, have a relevant role in degradation of extracellular matrix components and basal membrane [8]. Moreover, MMP are also associated with tumor suppressor regulation and with increased angiogenesis [9].

Among the most important members of MMPs family associated with urinary bladder urothelial carcinomas, MMP-2 (gelatinase A), MMP-9 (gelatinase B) and MMP14 (membrane type 1-MMP) have been reported to histological grade and tumoral invasion. By zymography and immunohistochemistry, increased expression of MMP-9 and activated MMP-2 were found significantly related to histological grade and tumoral invasion [10].

The development of tissue microarrays (TMA) has improved tumour assessment enabling the study of biomarker expression in specific areas of lesions, by spotting hundreds of different samples once a specialized pathologist has selected the most representative area for each site of interest. In bladder cancer, the use of TMA has been validated for simultaneous in situ analyses of hundreds of tumours at the DNA, RNA, and protein level, showing the ability to detect clinical-pathological correlations [11-12]. 
The objective of this study was to investigate the immunoexpression of MMP-2, MMP-9 and MMP-14 in both primary urinary bladder urothelial carcinomas and its respective regional lymph node metastases and to explore its association with histological features, including morphological variants and divergent differentiation of urothelial carcinoma.

\section{Materials and methods}

\section{$\underline{\text { Patients and specimens }}$}

Paraffin blocks from 61 radical cystectomy and 57 regional lymphadenectomy specimens operated on between December 2000 and October 2009 at the Division of Urology were retrieved from the files of Department of Pathology, Hospital das Clinicas, University of Sao Paulo School of Medicine. Inclusion criteria for this study encompassed muscle-invasive and locally advanced tumors (pT2a and higher according to TNM 2009/AJCC staging system).

\section{Assessment of pathological features}

Four micrometer histological sections were obtained from all original paraffin blocks and hematoxylin-eosin stained slides were submitted to histological review by a pathologist with special interest in urological pathology (RLM). Primary tumors were histologically classified according to 2004 World Health Organization and evaluated according to their gross size, focality, histological grade (low or high grade), architectural pattern of tumoral invasion (nodular, trabecular, infiltrative, mixed nodular and trabecular, mixed trabecular and infiltrative or mixed infiltrative and nodular), sarcomatoid component, squamous and/or glandular differentiation, morphological variant, lymphovascular invasion, carcinoma in situ, tumor stage and lymph node metastases.

\section{$\underline{\text { Tissue Micro-Arrays }}$}


The most anaplastic foci as well as the invasion front were selected to represent each primary tumor for Tissue Microarray (TMA). The respective paraffin blocks were marked and TMA constructed using a $1.0 \mathrm{~mm}$ gauge for tissue cylinder extraction of donor and placement on receptor block, using a Manual Tissue Microarrayer from Beecher Instruments (model MTA1). Each individual case was sampled four times on receptor block (twice from more high grade and twice from the invasive front) to the primary tumor and twice for the metastasis lymph node as a strategy for overcoming representativity losses inherent to TMA method, as stated in papers describing validation of this technology [13-15]. TMA paraffin blocks were sectioned on a Leica microtome in $4 \mu \mathrm{m}$ sections.

\section{$\underline{\text { Immunohistochemistry }}$}

In situ detection of MMP enzymes was achieved through immunohistochemistry (IHC) employing primary monoclonal antibodies to MMP-2 (clone CA4001/CA719E3C, Abcam, dilution 1:50), MMP-9 (clone 56-2A4, Abcam dilution 1:100) and MMP-14 (clone EP1264Y, Abcam,dilution 1:400). For IHC assays, sectioned slides from TMA paraffin blocks were dewaxed, rehydrated and submited to heat induced antigen retrieval in $\mathrm{pH}=6.0$ citrate buffer using a steamer for 30 minutes. Endogenous peroxydase was blocked using $6 \% \mathrm{H}_{2} \mathrm{O}_{2}$ and sections from primary tumors were incubated with primary antibodies at $37^{\circ} \mathrm{C}$ for 30 minutes followed by overnight incubation $(16 \mathrm{~h})$ at $4^{\circ} \mathrm{C}$. Avidin-biotin free polymer-based high-sensitive amplification system (Novolink, Novocastra, UK) and diaminobenzydin as chromogen were used for development of reaction products. Positive controls represented by human placenta, as well as negative controls established by omitting the primary antibody incubation step, were used in every reaction.

Evaluation of immunohistochemical expression of MMP-2, MMP-9 and MMP-14 was semi-quantitatively scored, either independently in neoplastic epithelium, in stroma and globally (combination of both epithelium and stroma). The grades of positively stained global, epithelial and stroma cells were evaluated as follows: 0, no stained cells; 1 , up to $10 \%$ of stained cells; 2 , from 11 to $20 \%$ of stained cells; 3 , from 21 to $30 \%$ of stained cells, successively until 10, 91 to $100 \%$ of stained cells. Intensity of staining for 
each MMPs was graded: 0 , negative; 1 , weak; 2 , moderate or strong. The score of MMPs expression was calculated multiplying the grade of proportion of stained cells $\mathrm{x}$ grade of MMP staining intensity. The higher scores of MMPs expression, global, in epithelium and stromal cells estimated the each area from primary tumor and lymph node metastases were selected. Thus, the final score of MMPs expression ranged from 0 to 20 points: 0 , no expression; 20, highest expression.

$\underline{\text { Statistical analysis }}$

Pathological variables were compared to the highest score of MMP-2, MMP-9 and MMP-14 global expression, epithelial cancer cells and stromal cells to using Pearson's chi-square test at $\mathrm{p}<0,05$. For statistical analysis, the program SPSS version 13.0 (SPSS Inc., Chicago, IL) was used.

\section{Results}

\section{Pathological features}

From 61 radical cystectomy specimens, 51 patients were male $(83.6 \%)$ and 10 female $(16.4 \%)$. Age varied from 40 to 84 years (mean \pm S.D.: $65.4 \pm 10.9$ y.o. and median 67 y.o.). Mean tumoral size was $4.3 \pm 2.2 \mathrm{~cm}$ and median $4.0 \mathrm{~cm}$. All cases were classified as high grade urothelial carcinoma, whereas 10 cases were multifocal. Architectural pattern of tumoral invasion was classified as nodular in 3 cases (4.9\%), trabecular in 7 (11.5\%), infiltrative in $13(21.3 \%)$, mixed infiltrative and trabecular in 33 $(54.1 \%)$ and mixed nodular and trabecular in 5 cases (8.2\%). Sarcomatoid component was at least focally detected in 9 cases (14.8\%). Squamous and glandular differentiation were present in $8(13.1 \%)$ and 6 cases $(9.8 \%)$ respectively. Histological variants of urothelial carcinoma were found in 13 cases (21.3\%): 4 nested, 3 micropapillary, 3 clear cell/glycogen rich, 1 small cell, 1 inverted pattern and 1 limphoepithelioma-like. Lymphovascular invasion was present in 48 cases (78.7\%) and carcinoma in situ in 28 cases $(45.9 \%)$. Pathological stages of primary tumor in radical cystectomy specimens 
were: pT2a -1 case $(1,6 \%)$, pT2b -11 cases $(18 \%)$, pT3a -19 cases $(31.1 \%)$, pT $3 b-16$ cases $(26.2 \%)$ and pT4a - 14 cases (23\%). From 57 cases with available lymph node dissection specimens, metastases were identified in 34 (59.6\%). Representative photomicrographs of relevant morphological features are depicted on figures 1 and 2 .

Fig. 1 Morphological features of urothelial carcinomas. Histological high grade (a). Squamous differentiation (b). Lymphovascular invasion (c). Infiltrative pattern of tumor invasion (d). H\&E, $400 x$

Fig. 2 Micropapillary variant(a). Clear cell/glycogen rich variant (b). Sarcomatoid component (cd). H\&E, a-b 200x, c-d 400x

\section{$\underline{\text { MMPs status }}$}

Despite inherent TMA methodological issues (spot physical or representatively losses), 61 cases were found adequate for MMP-2 evaluation in the primary tumours (100\%), 60 for MMP-9 (98\%) and 60 for MMP-14 (98\%). Lymph node metastases were adequately represented for MMP-2 evaluation in 32 cases (94\%), for MMP-9 in 31 (91\%) and for MMP-14 in 30 (88\%). Representative photomicrographs of MMPs expression can be seen in figure 3 .

Fig 3. MMPs Immunoexpression. MMP-9 both in epithelial and in stromal cells (global reactivity) (a). MMP-9 in stroma cells (b). MMP-9 epithelium neoplastic in infiltrative patter tumor (c). MMP-2 epithelium cells (d). MMP-14 sarcomatoid component (e). MMP-14 lymph node metastases (f). a 100x. b-f $400 x$

Tables 1, 2 and 3 show the frequency of scores in primary tumor for global expression, neoplastic epithelium expression and stromal expression of MMP-2, MMP-9 and MMP-14, respectively. 
Table 1 Scores of MMP-2 in primary tumour

\begin{tabular}{|c|c|c|c|c|c|c|}
\hline \multirow[b]{3}{*}{ Score } & \multicolumn{4}{|c|}{ "MMP-2 - Primary Tumour } & \multirow{2}{*}{\multicolumn{2}{|c|}{ Stroma }} \\
\hline & \multicolumn{2}{|c|}{ Global } & \multicolumn{2}{|c|}{ Neoplastic epithelium } & & \\
\hline & $\mathrm{n}$ & $\%$ & $\mathrm{n}$ & $\%$ & $\mathrm{n}$ & $\%$ \\
\hline 0 & 25 & 41 & 30 & 49,2 & 39 & 63,9 \\
\hline 1 & 18 & 29,5 & 15 & 24,6 & 19 & 31,1 \\
\hline 2 & 12 & 19,7 & 10 & 16,4 & 2 & 3,3 \\
\hline 3 & 3 & 4,9 & 3 & 4,9 & 1 & 1,6 \\
\hline 4 & 1 & 1,6 & 1 & 1,6 & - & - \\
\hline 6 & 2 & 3,3 & 2 & 3,3 & - & - \\
\hline TOTAL & 61 & 100 & 61 & 100 & 61 & 100 \\
\hline
\end{tabular}

Table 2 Scores of MMP-9 in primary tumour

\begin{tabular}{c|cccccc}
\hline \hline \multicolumn{2}{c|}{} & \multicolumn{7}{c}{ MMP-9 - Primary tumour } \\
\hline Score & & Global & \multicolumn{1}{c}{ Neoplastic epithelium } & \multicolumn{2}{c}{ Stroma } \\
\hline 0 & $\mathrm{n}$ & $\%$ & $\mathrm{n}$ & $\%$ & $\mathrm{n}$ & $\%$ \\
1 & 3 & 5 & 9 & 15 & 8 & 13,3 \\
2 & 14 & 23,3 & 9 & 15 & 19 & 31,7 \\
3 & 3 & 5 & 3 & 5 & 7 & 11,7 \\
4 & 4 & 6,7 & 8 & 13,3 & 2 & 3,3 \\
5 & 4 & 6,7 & 5 & 8,3 & 6 & 10 \\
6 & 3 & 5 & 6 & 10 & 1 & 1,7 \\
7 & 6 & 10 & 3 & 5 & 5 & 8,3 \\
8 & 2 & 3,3 & 3 & 5 & - & - \\
10 & 4 & 6,7 & 3 & 5 & 8 & 13,3 \\
12 & 4 & 6,7 & - & - & 3 & 5 \\
14 & 4 & 6,7 & 3 & 5 & 1 & 1,7 \\
16 & 2 & 3,3 & 1 & 1,7 & - & - \\
18 & 5 & 8,3 & 5 & 8,3 & - & - \\
\hline TOTAL & 60 & 100 & 60 & 100 & 60 & 100 \\
\hline \hline
\end{tabular}


Table 3 Scores of MMP-14 in primary tumour

\begin{tabular}{c|cccccc}
\hline \hline \multicolumn{2}{c}{} & \multicolumn{7}{c}{ MMP-14- Primary tumour } & \multicolumn{2}{c}{ Stroma } \\
\hline \multirow{2}{*}{ Score } & $\mathrm{n}$ & $\%$ & $\mathrm{n}$ & $\%$ & $\mathrm{n}$ & $\%$ \\
\hline 0 & - & - & 1 & 1,7 & 2 & 3,3 \\
1 & 3 & 5 & 8 & 13,3 & 13 & 21,7 \\
2 & 9 & 15 & 7 & 11,7 & 12 & 20 \\
3 & 7 & 11,7 & 6 & 10 & 7 & 11,7 \\
4 & 1 & 1,7 & 2 & 3,3 & 1 & 1,7 \\
5 & 2 & 3,3 & 3 & 5 & 1 & 1,7 \\
6 & 5 & 8,3 & 6 & 10 & 5 & 8,3 \\
7 & - & - & 1 & 1,7 & - & - \\
8 & 5 & 8,3 & 3 & 5 & 9 & 15 \\
9 & 1 & 1,7 & 1 & 1,7 & - & - \\
10 & 4 & 6,7 & 3 & 5 & 6 & 10 \\
12 & 7 & 11,7 & 5 & 8,3 & - & - \\
14 & 5 & 8,3 & 4 & 6,7 & 1 & 1,7 \\
16 & 7 & 11,7 & 6 & 10 & 2 & 3,3 \\
18 & 4 & 6,7 & 4 & 6,7 & 1 & 1,7 \\
\hline TOTAL & 60 & 100 & 60 & 100 & 60 & 100 \\
\hline \hline
\end{tabular}

Table 4 shows the frequency of scores in regional lymph node metastases for expression of MMP-2, MMP-9 and MMP-14. 
Table 4 Scores of MMP-2, -9 and -14 in lymph node metastases

\begin{tabular}{|c|c|c|c|c|c|c|}
\hline \multicolumn{7}{|c|}{ MMPs in lymph node metastases } \\
\hline \multirow{2}{*}{ Score } & \multicolumn{2}{|c|}{ MMP-2 } & \multicolumn{2}{|c|}{ MMP-9 } & \multicolumn{2}{|c|}{ MMP-14 } \\
\hline & $\mathrm{n}$ & $\%$ & $\mathrm{n}$ & $\%$ & $\mathrm{n}$ & $\%$ \\
\hline 0 & 12 & 37,5 & 4 & 12,9 & 4 & 13,3 \\
\hline 1 & 10 & 31,3 & 4 & 12,9 & 4 & 13,3 \\
\hline 2 & 3 & 9,4 & 3 & 9,7 & 6 & 20 \\
\hline 3 & 1 & 3,1 & 2 & 6,5 & 2 & 6,7 \\
\hline 4 & 2 & 6,3 & 3 & 9,7 & 2 & 6,7 \\
\hline 5 & 1 & 3,1 & 2 & 6,5 & 5 & 16,7 \\
\hline 6 & 1 & 3,1 & 1 & 3,2 & 1 & 3,3 \\
\hline 8 & 2 & 6,3 & 3 & 9,7 & 1 & 3,3 \\
\hline 9 & - & - & 1 & 3,2 & - & - \\
\hline 10 & - & - & 1 & 3,2 & 1 & 3,3 \\
\hline 12 & - & - & - & - & 1 & 3,3 \\
\hline 14 & - & - & 2 & 6,5 & 2 & 6,7 \\
\hline 16 & - & - & 3 & 9,7 & 1 & 3,3 \\
\hline 18 & - & - & 2 & 6,5 & - & - \\
\hline TOTAL & 32 & 100 & 31 & 100 & 30 & 100 \\
\hline
\end{tabular}

MMP status and pathological variables

Summary of the comparison of pathological features and MMP-2, MMP-9 and MMP-14 expression status are depicted at table 5. 
Table 5 Statistic association (p) between pathological features and MMPs expression

\begin{tabular}{|c|c|c|c|c|c|c|c|c|c|c|c|c|}
\hline \multirow{3}{*}{$\begin{array}{c}\text { Pathological } \\
\text { variables }\end{array}$} & \multicolumn{4}{|c|}{ MMP-2 - Score (p) } & \multicolumn{4}{|c|}{ MMP-9 - Score (p) } & \multicolumn{4}{|c|}{ MMP-14 - Score (p) } \\
\hline & \multicolumn{3}{|c|}{ Primary tumor } & \multirow{2}{*}{$\begin{array}{l}\text { Lymph } \\
\text { node }\end{array}$} & \multicolumn{3}{|c|}{ Primary tumor } & \multirow{2}{*}{$\begin{array}{c}\text { Lymph } \\
\text { node }\end{array}$} & \multicolumn{3}{|c|}{ Primary tumor } & \multirow{2}{*}{$\begin{array}{c}\text { Lymph } \\
\text { node }\end{array}$} \\
\hline & GL & EP & ST & & GL & EP & ST & & GL & EP & ST & \\
\hline Tumor size & 0,586 & 0,66 & 0,852 & 0,95 & 0,248 & 0,725 & 0,204 & 0,676 & 0,425 & 0,68 & 0,624 & 0,072 \\
\hline Tumor multifocality & 0,923 & 0,923 & 0,671 & 0,921 & 0,17 & 0,253 & 0,654 & 0,606 & 0,933 & 0,729 & 0,774 & 0,207 \\
\hline $\begin{array}{l}\text { Architectural pattern } \\
\text { of tumor invasion }\end{array}$ & 0,022 & 0,005 & 0,718 & 0,916 & 0,172 & $\mathbf{0 , 0 4 3}$ & $\mathbf{0 , 0 4 4}$ & 0,478 & 0,022 & 0,045 & 0,15 & 0,192 \\
\hline $\begin{array}{l}\text { Sarcomatoid } \\
\text { component }\end{array}$ & 0,27 & 0,13 & 0,062 & 0,254 & 0,759 & 0,411 & $\mathbf{0 , 0 3 6}$ & 0,189 & 0,906 & 0,942 & 0,071 & 0,213 \\
\hline $\begin{array}{l}\text { Squamous } \\
\text { differentiation }\end{array}$ & 0,564 & 0,599 & 0,062 & 0,434 & 0,033 & 0,475 & 0,286 & 0,944 & 0,73 & 0,723 & 0,939 & 0,306 \\
\hline $\begin{array}{l}\text { Glandular } \\
\text { differentiation }\end{array}$ & 0,831 & 0,941 & 0,761 & 0,905 & 0,779 & 0,869 & 0,831 & 0,776 & 0,852 & 0,871 & 0,394 & 0,781 \\
\hline Histological variants & 0,415 & 0,676 & 0,225 & 0,254 & 0,296 & 0,125 & 0,473 & 0,413 & 0,6 & 0,159 & 0,925 & 0,342 \\
\hline $\begin{array}{l}\text { Type of histological } \\
\text { variants }\end{array}$ & 0,966 & 0,881 & 0,967 & 0,299 & 0,625 & 0,32 & 0,984 & 0,021 & 0,568 & 0,557 & 0,983 & 0,324 \\
\hline $\begin{array}{l}\text { Lymphovascular } \\
\text { invasion }\end{array}$ & 0,771 & 0,847 & 0,733 & - & 0,303 & 0,309 & 0,722 & - & 0,655 & 0,934 & 0,662 & - \\
\hline Carcinoma in situ & 0,936 & 0,76 & 0,443 & 0,571 & 0,456 & 0,329 & 0,287 & 0,676 & 0,473 & 0,326 & 0,696 & 0,307 \\
\hline Staging tumor & 0,846 & 0,682 & 0,556 & 0,32 & 0,252 & 0,296 & 0,05 & 0,375 & 0,844 & 0,856 & 0,109 & 0,71 \\
\hline $\begin{array}{l}\text { Lymph node } \\
\text { metastases }\end{array}$ & 0,238 & 0,117 & 0,19 & - & 0,552 & 0,565 & 0,219 & - & 0,465 & 0,432 & 0,321 & - \\
\hline
\end{tabular}

GL: global expression; EP: neoplastic epithelium; ST: stroma

Statistical significant associations were observed between global and neoplastic epithelium MMP-2 expression and the architectural pattern of tumor invasion $(\mathrm{p}=0.022$ and $\mathrm{p}=0.005$, respectively). Immunoexpression of MMP-9 in epithelium ( $\mathrm{p}=0.043)$ and in 
stromal cells $(\mathrm{p}=0.044)$ was also directly related to the architectural pattern of tumour invasion. The presence of sarcomatoid component was associated with the immunoexpression to MMP-9 in stromal cells $(\mathrm{p}=0.036)$ and the squamous differentiation was associated with global expression of MMP-9 ( $\mathrm{p}=0.033)$. The immunoexpression of MMP-14, globally in the tumor components $(\mathrm{p}=0.022)$ as well as in epithelium $(\mathrm{p}=0.045)$ were also statistical associated to the architectural pattern of tumor invasion.

In the regional lymph nodes metastases, the only statistical association was found between immunoexpression of MMP-9 and the type of histological variants to the primary tumors $(\mathrm{p}=0.021)$.

\section{Discussion}

In the present study, the assessment of histopathological features of urothelial carcinoma, the gold standard for the assessment of diagnosis and prognosis, was related to different levels of MMPs expression in both epithelial neoplastic and tumor related stromal component. Wallard et al. using quantitative real time RT-PCR in normal bladder and in urothelial carcinoma specimens demonstrated a significant MMP-2 and MMP-14 expression in neoplastic stroma, whereas MMP-9 was detected in both, neoplastic epithelium and its related stroma [16]. MMPs immunoexpression was herein associated to histological grade and to infiltration depth in bladder wall. Kanayama et al. also demonstrated by RT-PCR, higher MMP-2 expression in muscle invasive and locally advanced bladder tumors when compared to pTa-pT1 stage tumors. Those authors also reported associations among higher MMP-2, TIMP-2 and MMP-14 expression with diminished survival [17]. By immunohistochemistry, Sumi et al. found that MMP-2 expression was significantly stronger in advanced stage and in high grade tumors than in low stage and low grade tumors [18]. Slaton et al. found higher ratio of MMP-9:Ecadherin levels as an independent prognostic indicator for disease progression, thus 
presenting immunodetection of MMP-9 as a potential marker for urothelial tumor progression [19].

Our results demonstrated an association between the architectural pattern of invasion and the immunoexpression of each of the three MMPs in epithelium or stroma. Among the 6 growth patterns assessed herein, the infiltrative pattern was the more frequent occurring as a major form (13 cases, 21.3\%) and associated with the trabecular pattern (33 cases, 54.1\%). Jimenez et al. assessing 93 cases treated by radical cystectomy reported the presence of infiltrative pattern (cells arranged in cords or isolated and permeating tumor stroma) associated with a lower mean survival (29 months) when compared with cases not featuring this pattern (mean survival 85 months, $p=0.06$ ) [6]. Once the infiltrative pattern is recognized as adverse prognostic factor, its association with MMPs expression highlights the importance of these metalloproteinases in invasion and progression of bladder urothelial carcinomas

In the present study, special attention was dedicated to the issue of divergent differentiation in invasive urothelial carcinoma. The MMP-9 global expression was significantly associated to squamous differentiation $(\mathrm{p}=0.033)$. Indeed, all 8 cases with squamous areas were found positive for MMP-9, including the case with the highest expression (score 18) in this series. The presence of squamous differentiation in urothelial tumors has been associated to higher grade and stage thus indicating a less favorable response to treatment [20-21]. These findings suggest that MMP-9 is functionally important in squamous differentiation in urothelial carcinomas, either by its direct action in development of squamous phenotype or indirectly by MMP-9 association in important processes of tumoral progression as growth factor and angiogenesis regulation.

Sarcomatoid carcinoma of urinary bladder is defined as a biphasic malignant neoplasm with evidence of both epithelial and mesenchymal differentiation [22]. In the present series, this component was detected in 9 from 61 cases $(14.8 \%)$, with its proportion varying from small to large areas of primary tumor. All 9 cases with sarcomatoid areas did express MMP-9 and MMP-14 in stromal components, whereas MMP-2 was found in 5/9 cases. Moreover, the presence of sarcomatoid areas was 
significantly related to MMP-9 expression in stroma $(\mathrm{p}=0.036)$ and a trend for stromal MMP-2 and MMP-14 expression ( $\mathrm{p}=0,062$ and $\mathrm{p}=0.071$, respectively). The presence of sarcomatoid carcinoma has been reported as related to advanced stage. In a series encompassing 26 cases of sarcomatoid carcinomas, Lopez-Beltran et al. detected just one pT2 case, whereas the other 25 were staged as pT3 or pT4 categories [23]. Similarly, among the 18 cases reported by Torenbeeck et al., described $44 \%$ from pT2 and $56 \%$ as pT3/pT4 [24]. A possible explanation for phenotypic change in this type of tumor would be cellular reprograming induced by extracellular stromal microenvironment signals, resulting in the transdiffentiation from the epithelial to mesenchymal phenotype of neoplastic cells [25]. The epithelial-mesenchymal transition (EMT) is marked by loss of expression of intercellular junction protein E-cadherin by epithelial cells and acquisition of mesenchymal related markers like vimentin [26-27]. Ikegami et al. studied 14 cases of bladder sarcomatoid urothelial carcinomas and compared the immunohistochemical expression of cell adhesion molecules (E-cadherin, CD44 and CD44v6) in sarcomatoid and carcinomatous phenotypes, demonstrating lower expression levels of these molecules in sarcomatoid areas of these tumors [28]. Also, in vitro studies have shown that EMT is a dynamic processes in which an increasing number of different signaling pathways are involved, including cell growing, cytokines and the MMPs properly [29]. EMT can play a role in the process of increased cell motility, providing its means to extracellular matrix migration and increased potential to tumoral invasion. Matsui et al. searching for the role of integrin-linked kinase showed in cell culture studies that bladder carcinoma cells have the regulation of MMP-9 and E-cadherin expression associated with the ability of neoplastic cell invasion and the capability of EMT developments [30]. Taken together, these findings demonstrate an association of MMP with the process of tumoral invasion, also influencing the EMT, in this series of cases demonstrated by the association of sarcomatoid component with the three MMPs studied herein.

In our study, 7 cases presenting at least one of the morphological variants (2 nested, 3 micropapillary, 1 clear cell/glycogen rich and 1 case small cell) and positive regional lymph node metastases also showed MMP-9 immunoexpression in the metastasis itself, thus showing a significant association between the type of histological variant at the from primary tumor and MMP immunoexpression in the metastases 
$(\mathrm{p}=0.021)$. The presence of morphological variants is associated with more aggressive biological behavior of urothelial carcinomas and thus might demand the development of special therapeutical approach for these cases [2]. Besides to invasive behavior of urothelial carcinomas, the MMPs have also been reported as active factors for the development of metastases. In experimental assays, the number of metastasis is reduced by downregulation of MMP-9 in cancer cells [31]. Thus, morphological variants of urothelial carcinomas might promote the MMP-9 expression in metastases, facilitating the neoplastic dissemination far away from primary tumor and justifying the more aggressive potential in these carcinomas.

Our observations, in keeping with previous work from literature, further endorses the need for continuing search for details of morphological presentation of neoplasms such as evidences of the presence of divergent differentiation as variables can identify subgroups of bladder tumors where the differential expression of MMPs could indicate more likely progression and thus assist in the search for more effective on therapy for these patients.

Conflict of interest The authors declare that they have no conflict of interest.

\section{References}

1. Jemal A, Bray F, Center MM, Ferlay J, Ward E, Forman D (2011) Global cancer statistics. CA Cancer J Clin. 61:69-90

2. Amin MB (2009) Histological variants of urothelial carcinoma: diagnostic, therapeutic and prognostic implications. Mod Pathol. 22 Supp:S96-S118 
3. Proctor I, Stoeber K, Williams GH (2010) Biomarkers in bladder cancer. Histopathology. 57:1-13

4. Sylvester RJ, van der Meijden AP, Oosterlinck W, Witjes JA, Bouffioux C, Denis L, et al (2006) Predicting recurrence and progression in individual patients with stage Ta T1 bladder cancer using EORTC risk tables: a combined analysis of 2596 patients from seven EORTC trials. Eur Urol. 49:466-5; discussion 475-477

5. Cheng L, Weaver AL, Leibovich BC, Ramnani DM, Neumann RM, Scherer BG, et al (2000) Predicting the survival of bladder carcinoma patients treated with radical cystectomy. Cancer. 88:2326-2332

6. Jimenez RE, Gheiler E, Oskanian P, Tiguert R, Sakr W, Wood DP, Jr., et al (2000) Grading the invasive component of urothelial carcinoma of the bladder and its relationship with progression-free survival. Am J Surg Pathol. 24:980-987

7. Lotan Y, Gupta A, Shariat SF, Palapattu GS, Vazina A, Karakiewicz PI, et al (2005) Lymphovascular invasion is independently associated with overall survival, cause-specific survival, and local and distant recurrence in patients with negative lymph nodes at radical cystectomy. J Clin Oncol. 23:6533-6539

8. Egeblad M, Werb Z (2002) New functions for the matrix metalloproteinases in cancer progression. Nat Rev Cancer. 2:161-174

9. Seandel M, Noack-Kunnmann K, Zhu D, Aimes RT, Quigley JP (2001) Growth factor-induced angiogenesis in vivo requires specific cleavage of fibrillar type I collagen. Blood. 97:2323-2332

10. Papathoma AS, Petraki C, Grigorakis A, Papakonstantinou H, Karavana V, Stefanakis S, et al (2000) Prognostic significance of matrix metalloproteinases 2 and 9 in bladder cancer. Anticancer Res. 20(3B):2009-2013 
11. Nocito A, Bubendorf L, Tinner EM, Suess K, Wagner U, Forster T, et al (2001) Microarrays of bladder cancer tissue are highly representative of proliferation index and histological grade. J Pathol. 194:349-357

12. Hartmann A (2008) Tissue microarray studies in bladder cancer. Scand J Urol Nephrol Suppl. 218:141-146

13. Das K, Mohd Omar MF, Ong CW, Bin Abdul Rashid S, Peh BK, Putti TC, et al (2008) TRARESA: a tissue microarray-based hospital system for biomarker validation and discovery. Pathology. 40:441-449

14. Hassan S, Ferrario C, Mamo A, Basik M. Tissue microarrays: emerging standard for biomarker validation (2008) Curr Opin Biotechnol. 19:19-25

15. Boone J, van Hillegersberg R, van Diest PJ, Offerhaus GJ, Rinkes IH, Kate FJ (2008) Validation of tissue microarray technology in squamous cell carcinoma of the esophagus. Virchows Arch. 452:507-514

16. Wallard MJ, Pennington CJ, Veerakumarasivam A, Burtt G, Mills IG, Warren A, et al (2006) Comprehensive profiling and localisation of the matrix metalloproteinases in urothelial carcinoma. Br J Cancer. 94:569-577

17. Kanayama H, Yokota K, Kurokawa Y, Murakami Y, Nishitani M, Kagawa S (1998) Prognostic values of matrix metalloproteinase-2 and tissue inhibitor of metalloproteinase-2 expression in bladder cancer. Cancer. 82:1359-1366

18. Sumi T, Yoshida H, Hyun Y, Yasui T, Matsumoto Y, Hattori K, et al (2003) Expression of matrix metalloproteinases in human transitional cell carcinoma of the urinary bladder. Oncol Rep. 10:345-349

19. Slaton JW, Millikan R, Inoue K, Karashima T, Czerniak B, Shen Y, et al (2004) Correlation of metastasis related gene expression and relapse-free survival in patients with locally advanced bladder cancer treated with cystectomy and chemotherapy. J Urol. 171(2 Pt 1):570-574 
20. Lopez-Beltran A, Requena MJ, Alvarez-Kindelan J, Quintero A, Blanca A, Montironi R (2007) Squamous differentiation in primary urothelial carcinoma of the urinary tract as seen by MAC387 immunohistochemistry. J Clin Pathol. 60:332-335

21. Lopez-Beltran A, Cheng L (2006) Histologic variants of urothelial carcinoma: differential diagnosis and clinical implications. Hum Pathol. 37:1371-1388

22. Lopez-Beltran A, Sauter G, Gasser T, Hartmann A, Schmitz-Dra“ger BJ, Helpap B et al (2004) Urothelial tumors: infiltrating urothelial carcinoma. In: Eble JN, Sauter G, Epstein JI, Sesterhenn IA (ed) Pathology ang genetics of tumours of the urinary system and male genital organs. IARC Press, Lyon. pp 93-109

23. Lopez-Beltran A, Pacelli A, Rothenberg HJ, Wollan PC, Zincke H, Blute ML, et al (1998) Carcinosarcoma and sarcomatoid carcinoma of the bladder: clinicopathological study of 41 cases. J Urol. 159:1497-14503

24. Torenbeek R, Blomjous CE, de Bruin PC, Newling DW, Meijer CJ (1994) Sarcomatoid carcinoma of the urinary bladder. Clinicopathologic analysis of 18 cases with immunohistochemical and electron microscopic findings. Am J Surg Pathol. 18:241249

25. Cheng L, Zhang S, Alexander R, Maclennan GT, Hodges KB, Harrison BT, et al (2011) Sarcomatoid carcinoma of the urinary bladder: the final common pathway of urothelial carcinoma dedifferentiation. Am J Surg Pathol. 35:e34-46

26. Polyak K, Weinberg RA (2009) Transitions between epithelial and mesenchymal states: acquisition of malignant and stem cell traits. Nat Rev Cancer. 9:265-273

27. McConkey DJ, Lee S, Choi W, Tran M, Majewski T, Siefker-Radtke A, et al (2010) Molecular genetics of bladder cancer: Emerging mechanisms of tumor initiation and progression. Urol Oncol. 28:429-440 
28. Ikegami H, Iwasaki H, Ohjimi Y, Takeuchi T, Ariyoshi A, Kikuchi M (2000) Sarcomatoid carcinoma of the urinary bladder: a clinicopathologic and immunohistochemical analysis of 14 patients. Hum Pathol. 31:332-340

29. Barr S, Thomson S, Buck E, Russo S, Petti F, Sujka-Kwok I, et al (2008) Bypassing cellular EGF receptor dependence through epithelial-to-mesenchymal-like transitions. Clin Exp Metastasis. 25:685-693

30. Matsui Y, Assi K, Ogawa O, Raven PA, Dedhar S, Gleave ME, et al (2011) The importance of integrin-linked kinase in the regulation of bladder cancer invasion. Int $\mathbf{J}$ Cancer. doi: 10.1002/ijc.26008

31. Hua J, Muschel RJ (1996) Inhibition of matrix metalloproteinase 9 expression by a ribozyme blocks metastasis in a rat sarcoma model system. Cancer Res. 56:5279-5284 


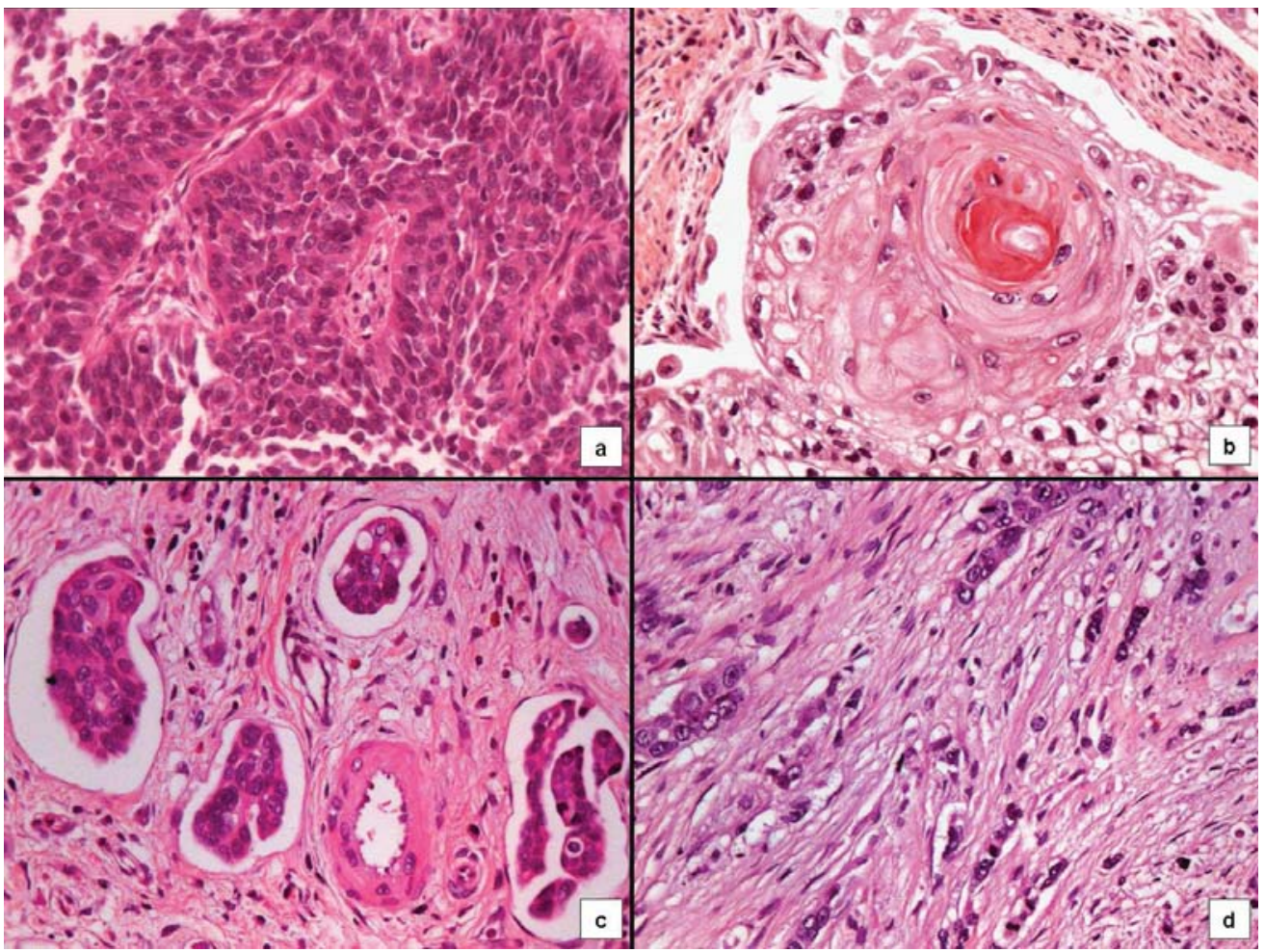

Fig. 1 Morphological features of urothelial carcinomas. Histological high grade (a). Squamous differentiation (b). Lymphovascular invasion (c). Infiltrative pattern of tumor invasion (d). H\&E, $400 x$

$244 \times 183 \mathrm{~mm}(150 \times 150 \mathrm{DPI})$ 


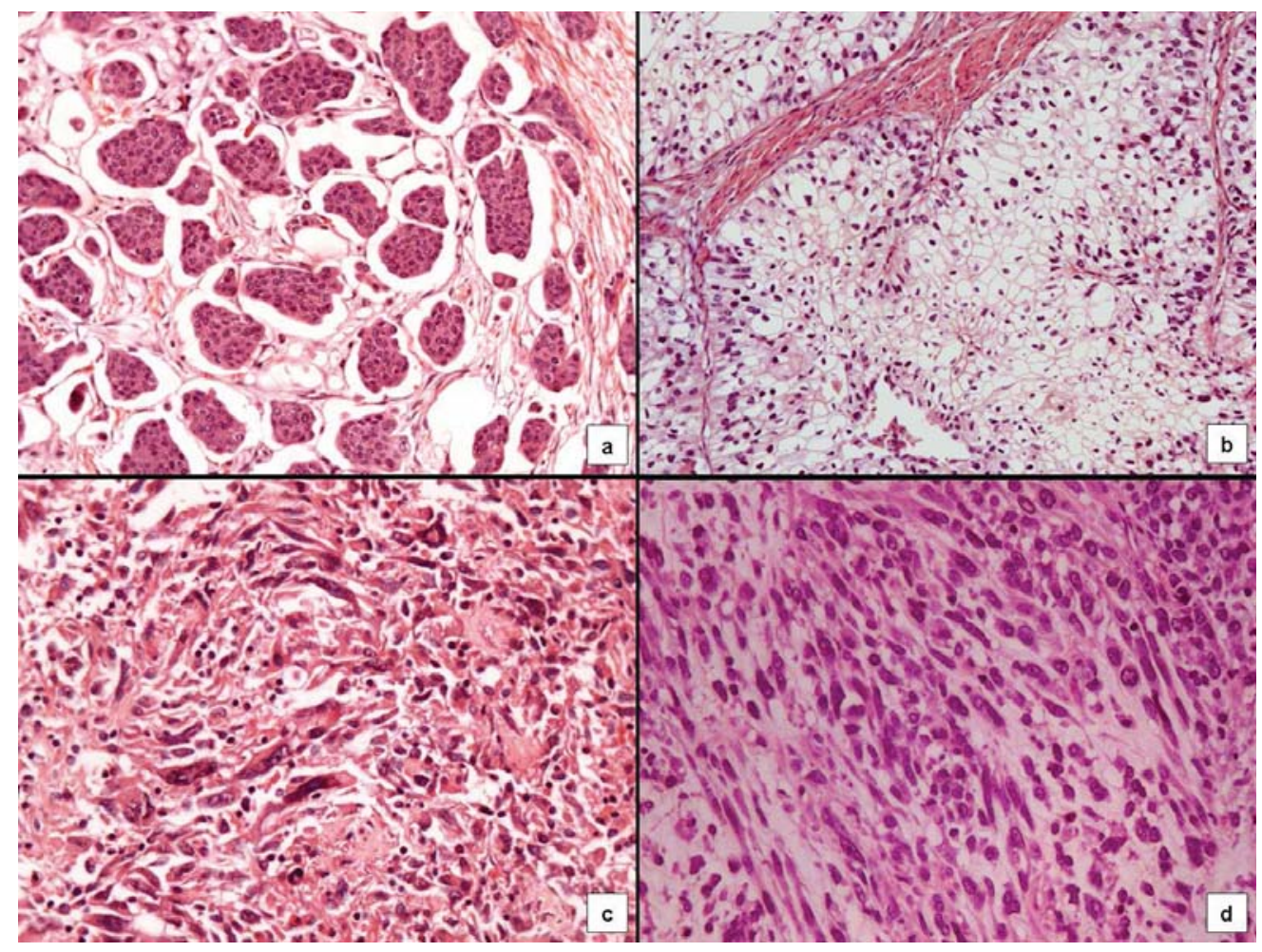

Fig. 2 Micropapillary variant (a). Clear cell/glycogen rich variant (b). Sarcomatoid component (c-d). $\mathrm{H} \& \mathrm{E}, \mathrm{a}-\mathrm{b}$ 200x, c-d 400x $243 \times 183 \mathrm{~mm}(150 \times 150 \mathrm{DPI})$ 


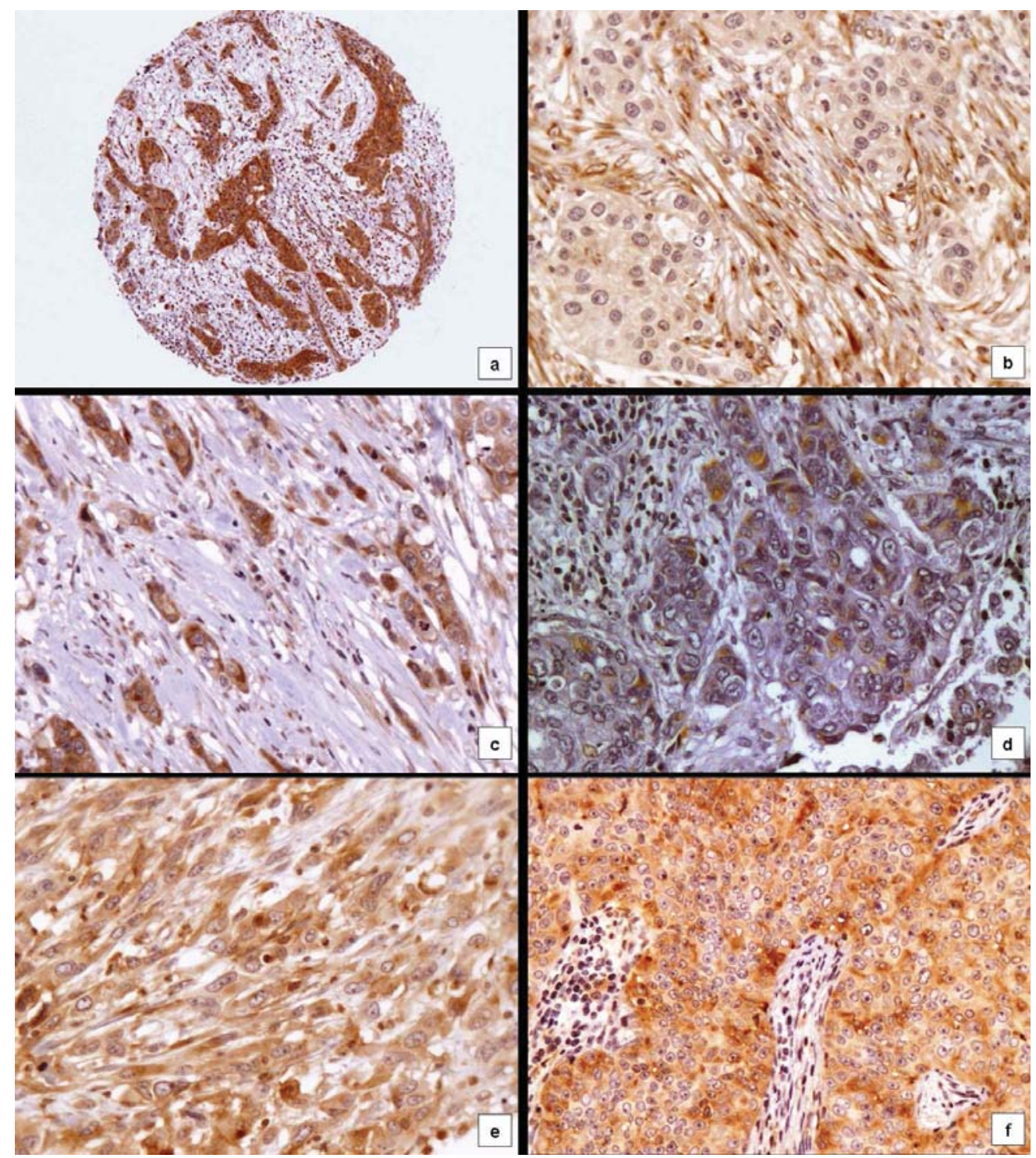

Fig 3. MMPs Immunoexpression. MMP-9 both in epithelial and in stromal cells (global reactivity) (a). MMP-9 in stroma cells (b). MMP-9 epithelium neoplastic in infiltrative patter tumor (c). MMP-2 epithelium cells (d). MMP-14 sarcomatoid component (e). MMP-14 lymph node metastases (f). a 100x. b-f 400x

$245 \times 277 \mathrm{~mm}(150 \times 150 \mathrm{DPI})$ 